NBER WORKING PAPER SERIES

\title{
ADDRESSING GLOBAL ENVIRONMENTAL EXTERNALITIES: TRANSACTION COSTS CONSIDERATIONS
}

\author{
Gary D. Libecap \\ Working Paper 19501 \\ http://www.nber.org/papers/w19501
NATIONAL BUREAU OF ECONOMIC RESEARCH
1050 Massachusetts Avenue
Cambridge, MA 02138
October 2013

I have benefitted from detailed comments provided by Janet Currie and three referees, as well as by Eric Edwards, Marc Law, Bryan Leonard, Trevor O'Grady, and Rebecca Toseland who reviewed various drafts. Other useful suggestions were provided by Doug Allen, Lee Alston, Terry Anderson, Chris Costello, Zack Donohew, Ted Groves, Rögnvaldur Hannesson, P.J. Hill, Charles Kolstad, Dean Lueck, Nick Parker, Mary Shirley, and participants in the All Chicago Area Economic History Workshop, May 3, 2012; ISNIE conferences June 14-16, 2012 and June 20-22, 2013; the PERC Lone Mountain Workshop August 6, 2012 and "Tackling the Global Fisheries Challenge" Conference, November 14-15, 2012; and the ASU-MBL Workshop on History of Sustainability Science, Woods Hole, May 16-22, 2013, as well as seminars at Whitman College, October 26, 2011 and Carleton College, May 2, 2013. Literature recommendations were provided by Arun Agrawal, Marty Anderies, Krister Andersson, Stephen Ansolabehere, Susan Aaronson, Mike Bordo, Dan Cole, Tom Evans, Burnell Fischer, Clark Gibson, Doug Irwin, Marco Janssen, Kerry Krutilla Mike McGinnis, Amelia Porges, Amy Poteete, Ty Robbins, Chris Severen, Edella Schlager, Michael Schoon, and David Victor. Excellent research assistance was provided by Serena Canaan, Karin Donhowe, and Andrew Knauer. Research support was given by the Earhart Foundation, the Lone Mountain Fellowship (PERC), and the Hoover Institution's Property Rights Task Force, Stanford. The views expressed herein are those of the author and do not necessarily reflect the views of the National Bureau of Economic Research.

NBER working papers are circulated for discussion and comment purposes. They have not been peerreviewed or been subject to the review by the NBER Board of Directors that accompanies official NBER publications.

(C) 2013 by Gary D. Libecap. All rights reserved. Short sections of text, not to exceed two paragraphs, may be quoted without explicit permission provided that full credit, including $\odot$ notice, is given to the source. 
Addressing Global Environmental Externalities: Transaction Costs Considerations

Gary D. Libecap

NBER Working Paper No. 19501

October 2013

JEL No. D23,D62,H87,N5,Q2,Q3,Q38,Q5

\begin{abstract}
Is there a way to understand why some global environmental externalities are addressed effectively whereas others are not? The transaction costs of defining the property rights to mitigation benefits and costs is a useful framework for such analysis. This approach views international cooperation as a contractual process among country leaders to assign those property rights. Leaders cooperate when it serves domestic interests to do so. The demand for property rights comes from those who value and stand to gain from multilateral action. Property rights are supplied by international agreements that specify resource access and use, assign costs and benefits including outlining the size and duration of compensating transfer payments and determining who will pay and who will receive them. Four factors raise the transaction costs of assigning property rights: (i) scientific uncertainty regarding mitigation benefits and costs; (ii) varying preferences and perceptions across heterogeneous populations; (iii) asymmetric information; and (iv) the extent of compliance and new entry. These factors are used to examine the role of transaction costs in the establishment and allocation of property rights to provide globally-valued national parks, implement the Convention on the International Trade in Endangered Species (CITES), execute the Montreal Protocol to control emissions that damage the stratospheric ozone layer, set limits on harvest of highly-migratory ocean fish stocks, and control greenhouse gas emissions (GHG).
\end{abstract}

Gary D. Libecap

Bren School of Environmental Science

and Management and Economics Department

University of California, Santa Barbara

Bren Hall 4412

Santa Barbara, CA 93106-5131

and ICER

and also NBER

glibecap@bren.ucsb.edu 
Many of the world's most challenging environmental externalities are broadly spread, inflicting costs in terms of lost biodiversity and damaged ecosystems, depletion of terrestrial and marine species, and emissions that harm human health and generate climate change. Some are truly global, for instance, greenhouse gas (GHG) releases. Others are more regional but either involve global agents, as with the harvest of migratory wild-ocean fish stocks, or are globally valued but locally depleted, as the reduction of unique ecosystems. This review focuses on these expansive externalities. "Global environmental externalities" is an umbrella term that refers to the negative environmental consequences of direct natural resource use and human production and consumption activities arising in broad spatial settings in the presence of incomplete property rights. It does not include externalities that occur in trans-boundary resource use by parties from adjacent nations.

Since 1920 there have been more than 140 international environmental agreements to confront such externalities, with over half signed since 1973. Including more informal conventions raises the number beyond 700 (Barrett 2005, 133-95, 165-94; O'Neill 2009, 1-2, 3436; 73-5; Mitchell 2012). Among these are generally successful multinational efforts to protect globally-valued, unique ecosystems, animal and plant species, and to control certain damaging emissions. As of 2012 there were at least 610 United Nations Educational, Scientific and Cultural Organization (UNESCO) biosphere reserves in 117 countries (UNESCO World Network of Biosphere Reserves) ${ }^{2}$ and nearly 7,000 national parks classified by the International Union for Conservation of Nature (IUCN) as Category II protected areas. ${ }^{3}$ The Convention on International Trade in Endangered Species (CITES) regulates the trade in endangered wild

\footnotetext{
${ }^{2}$ http://www.unesco.org/new/en/natural-sciences/environment/ecological-sciences/biosphere-reserves/worldnetwork-wnbr/wnbr/

${ }^{3}$ http://www.iucn.org/about/work/programmes/gpap_home/gpap_quality/gpap_pacategories/gpap_pacategory2/
} 
animals and plants. ${ }^{4}$ As of September 2012, 176 nations were parties to CITES which covers 5,000 animal and 29,000 plant types (Barbier et al 1990, Bulte and van Kooten 1999, Kremer and Morcom 2000, Missios 2004). ${ }^{5}$ The Montreal Protocol on Substances that Deplete the Ozone Layer of 1987 phased out of the production of chlorofluorocarbons (CFCs) in developed countries and halted their trade among all countries. By 2009 the Protocol had been ratified by 196 governments (Beron et al 2003; Parson 2003; Barrett 2005, 221-53; Velders et al 2007; Young 2010, 23-52). ${ }^{6}$

In sharp contrast, there have been no effective international agreements to reduce harvests of many valuable, highly-migratory fish species. Fishing capacity and vessel numbers are increasing and stocks continue to be driven down to unsustainable levels (Upton and Vitalis 2003; Myers and Worm 2003; Devine et al. 2006; Maguire et al. 2006; Beddington et al. 2007; Worm et al. 2009; McWhinnie 2009; Food and Agricultural Organization (FAO) 2010; 2012, 4, 54-55; and Pinsky et al. 2011). ${ }^{7}$ Similarly, there have been no sustained multilateral controls on the anthropogenic release of greenhouse gases that contribute to climate change. The Kyoto Protocol of 1997 called for developed countries to reduce GHG emissions by at least 5\% from 1990 levels by $2008-2012 .^{8}$ Less-developed countries were exempted, and the U.S. did not ratify

\footnotetext{
${ }^{4} \mathrm{http} / / / \mathrm{www} . i u c n . o r g /$. International agreements for the protection of endangered species have a long history among developed economies. Prominent examples include the 1900 and 1933 London Conventions on conservation largely in Africa, the 1940 Washington Convention on Nature Protection and Wildlife Preservation in the Western Hemisphere, and the 1972 Convention for the Conservation of Antarctic Seals.

${ }^{5}$ See http://www.cites.org/eng/app/appendices.php for the species listed in CITES Appendices as examined below.

${ }^{6} \mathrm{~A}$ list of the chemicals is in Brief primer on the Montreal Protocol http://ozone.unep.org/Publications/MP_Brief_Primer_on_MP-E.pdf.

${ }^{7}$ China has the largest growth in share of world fish production from both wild capture and aquaculture, increasing from 7\% in 1961 to 35\% in 2010 (FAO 2012, 3). Vukas and Vidas (2001) and Food and Agricultural Organization (2012, 17-18) discuss flags of convenience as a source of new entry. The overall annual losses are estimated to be $\$ 50$ billion or more relative to more optimal fishing practices (Arnason et al. 2009); Lischewski 2010). Agnew et al (2009) estimate the costs of illegal, unreported and unregulated (IUU) fishing alone at \$10-23.5 billion annually ${ }^{8}$ unfccc.int/kyoto_protocol/items/2830.php. The Protocol to the United Nations Framework Convention on Climate Change (UNFCCC) was adopted at the third session of the Conference of the Parties (COP 3) in Kyoto, Japan and came into force after 55 Parties to the UNFCCC in Annex I (regulated economies), accounting for at least $55 \%$ of total $\mathrm{CO}_{2}$ emissions in 1990 ratified the agreement.
} 
the Protocol, which was terminated in 2012 with no replacement framework. ${ }^{9}$ Overall, GHG emissions have grown, primarily from sources in developing countries (Barrett 2010, 241; Victor 2011, 32-9, 204, 208). ${ }^{10}$

What is an economist to make of this variation in the success of international collective efforts to address global environmental externalities? What are the underlying factors that promote or inhibit action? And what are the opportunities for new research? This review focuses on the transaction costs of domestic and international negotiations to assign property rights to rents arising from mitigation to explain different cooperative responses. There is no significant literature that applies transaction costs to the analysis of environmental externalities. This review provides a framework for theoretical modeling and for empirical research. It outlines testable implications and illustrates how they can be applied to the analysis of a range of global environmental externalities where transaction costs and cooperative results vary.

The role of property rights in defining who bears the costs and benefits of decision making in resource use are described by Libecap 1989a; Barzel 1997; and Merrill and Smith 2010. If property rights fully specify access and uses, rent dissipation is avoided (Gordon 1954; Hardin 1968; Cheung 1970) and private and social costs and benefits are aligned (Pigou 1920; Buchanan and Stubblebine 1962; Baumol 1972; Meade 1973; Dahlman 1979). Property rights institutions, however, are costly to introduce (Demsetz 1967) and are necessarily incomplete (Coase 1960). The relevant assets must be measured, bounded, and enforced (Barzel 1982); some parties must be excluded; and, in environmental contexts, consumption must often be delayed or foregone. Prices rise to reflect social costs, potentially lowering real incomes for consumers and

\footnotetext{
${ }^{9}$ http://unfccc.int/kyoto_protocol/status of ratification/items/2613.php. http://www.guardian.co.uk/environment/2011/dec/16/russia-canada-kyoto-protocol.

${ }^{10}$ Accordingly, attention is directed to a "post-Kyoto world" (Aldy and Stavins 2007, 2010). For emissions, see http://www.eia.gov/cfapps/ipdbproject/IEDIndex3.cfm?tid=90\&pid=44\&aid=8.
} 
input suppliers. Some resources like the global atmosphere are not boundable so mitigation benefits are not appropriable. There may be ancillary health benefits or gains from avoiding costly climatic change that are captured by agents in specific regions but the broader atmosphere itself is not excludable. Free riding on mitigation is an impediment to international cooperation. Defining property rights to broad, fugitive resources, such as highly-migratory fish stocks or to the benefits and costs of policies to protect the atmosphere, therefore presents important challenges.

The assignment of property rights is a contractual process that occurs informally within local groups to address small-scale externalities (Ostrom 1990); more formally within countries through domestic political processes to confront broader externalities (Libecap 1978, 1989a, 2007); and through multilateral agreements to control transnational ones (Hannesson 2004). The latter are naturally most complex because they involve representatives of diverse, sovereign countries. Countries are collections of heterogeneous interests who will benefit (or be harmed) in different ways from non-cooperation or cooperation, or importantly, from different distributions of property rights. How these interests respond to the anticipated costs and benefits of the property rights assigned through international collective action affects the positions taken by country leaders in multilateral negotiations and in the cooperative mitigation that is proposed. Although the establishment of property rights institutions increases total rents, the resulting distribution of rents is not equal unless transfer payments are made. The negotiations underlying the definition of transfer payments themselves, however, change the size and flow of rents achievable. Distributional conflicts are inherent in property rights definition and enforcement, and they critically influence the nature and timing of the rights that emerge (Libecap 1989a).

In terms of global environmental externalities, international agreements that assign 
property rights to control open-access losses are potentially most straightforward for natural resources such as fisheries (Hannesson 2004). International conventions grant nations control over a portion of the multinational resource and country leaders, in turn, either assign direct property rights within their jurisdiction to users (for example, individual transferable quotas in fisheries) or regulate access and use in ways that grant short-term rents to specified parties (for example, those fishers who receive annual licenses under limited licensing regimes).

The property rights arising from international cooperation to control the external costs from production and consumption on the natural environment, such as releases of CFCs or GHGs, are less straightforward. International agreements assign mitigation responsibilities to entities within designated countries via mandated changes in production processes and consumption patterns and through designation of transfer payments within and across nations. These actions, which shift consumption and production to better reflect social costs, necessarily impose private costs that are borne by producers, consumers, and input suppliers in regulated jurisdictions. Concerns regarding their incidence within countries can be addressed by transfers. But transfers across countries may also be needed to achieve international cooperation. It is costly to reach agreement over the parties to be compensated, who will pay, the amounts involved, the duration of payments, and the institutions for delivery. There also are compliance and enforcement costs. International mitigation policies determine the size and assignment of these costs across countries and among populations within them.

The benefits of international environmental agreements often are not appropriable. Protection of biodiversity, unique habitats, endangered plant and animal species, and reduction in harmful CFC or GHG emissions generate broad global public goods that, by definition, are not excludable. Even so, some parties value or benefit from those public goods more than do others 
and they gain more from their provision. Hence, these parties capture rents or added value from mitigation. In this review, the delegation of costs and benefits through international environmental agreements are viewed as property rights to the rents arising from mitigation. The costs and benefits are not allocated proportionately across countries or among parties inside them. Negotiations over distributions are the focus of bargaining to achieve cooperative efforts in addressing global environmental externalities.

One should think of the demand for international cooperation and the demand for property rights for broad externality control as synonymous. The demand comes from those who greatly value externality mitigation and expect to capture rents. Property rights are supplied by international agreements, either through direct controls on natural resource access and use or through controls on the external environmental effects of production. Country leaders cooperate when it serves their domestic interests to do so. When this is the case, international arrangements for mitigation are self-enforcing and collectively rational, relative to unilateral defection (Barrett 1994; 2005, 33, 55-78, 195; McGinty 2007; Chander and Tulkens 2008).

Transaction costs are the costs of establishing and maintaining property rights to the rents gained from mitigation within and across countries. This definition builds on Allen $(1991,2000)$ and Barzel (1985). Both follow Coase $(1960,1992)$, who used transaction costs to examine market exchange and firm organization. ${ }^{11}$ Demsetz (1968) and Williamson (1979, 2010) apply transaction costs to explain firm behavior. Krutilla and Krause (2010) are among the few to use transaction costs to examine the determinants of environmental policy.

In the context of global environmental externality mitigation, four factors raise transaction costs: (1) scientific uncertainty; (2) varying preferences and perceptions; (3)

\footnotetext{
${ }^{11}$ Useful summaries of key points made by Coase are in Cooper (1995); DeMeza (1998); and Medema and Zerbe (2000).
} 
asymmetric information; and (4) lack of compliance and new entry. These factors suggest four testable implications regarding the effect of transaction costs on the likelihood of international collective action to address externalities:

(1) The greater the scientific uncertainty about the size, timing, and distribution of externality costs (mitigation benefits) and the costs of addressing them, the less likely there will be agreement on property rights.

(2) The greater the diversity of preferences and perceptions across parties over the value and costs of externality control, the less likely there will be agreement on property rights. (3) The greater the asymmetry of information about contributions to the externality, natural system responses, and compliance, the less likely there will be agreement on property rights.

(4) The greater the anticipation of agreement violations and new entry, the less likely there will be agreement on property rights.

These four implications are referred to throughout the review in suggesting research agendas. They also highlight variables to be included in theoretical modeling of transaction costs and cooperation to confront global environmental externalities.

There is a relatively large game-theoretic literature that investigates international environmental agreements (IEAs) by analyzing the strategic interactions of countries in the presence of a multinational environmental externality. The principal focus is on cooperation to control GHG emissions. In this literature, countries are modeled as individual players who choose whether to cooperate with other players in their abatement decisions. The extent of cooperation typically is measured by the number of countries that voluntarily agree to mitigate the externality relative to a non-cooperative outcome. 
The basic approach of the IEA literature and some of its key contributions are reviewed below. This is followed by a discussion of limitations to this methodology and how incorporating a transaction costs framework can further our analysis of multinational efforts. Some of the IEA literature incorporates institutional features into the game theoretic framework. ${ }^{12}$ Overall, however, the current IEA approach is not well suited to examine the institutional details involved in developing, coordinating, and enforcing such agreements. To motivate a transaction costs approach, the literature on transaction costs and local common pool resources (CPRs) is reviewed after the discussion of the IEA literature. Insights from CPR literature are then used to discuss how varying transaction costs impact the definition of property rights and the likelihood of cooperation in the context of several different international environmental externalities.

\section{The International Environmental Agreements Literature and Transaction Costs}

The defining characteristic of global externality abatement and the provision of global public goods is that there is no single institution empowered to coerce cooperation among sovereign nations. Successful agreements must be self-enforcing (Barrett 1994, 1999, 2005). The early game-theoretic work on IEAs is similar to the cartel literature (d'Aspremont et al 1983; Donsimoni et al 1986) in that it focuses on the formation of stable coalitions. The dominant model follows a general two-stage setup proposed by Barrett (1994). In the first stage, countries simultaneously decide whether to join a cooperative IEA. The second stage has two sub-stages. In the first sub-stage, members of the IEA are assumed to choose actions that maximize their joint payoff. In the second sub-stage, non-members are assumed to choose actions that maximize their individual payoff, taking the actions of the coalition as given. ${ }^{13}$

\footnotetext{
${ }^{12}$ See Finus (2001) for examples of models that endogenize the choice of policy instruments.

${ }^{13}$ The second stage is therefore characteristic of a Stackelberg game where the cooperating coalition plays the role of Stackelberg leader with the expectation that fringe nations outside the IEA will free ride on their actions (Rubio and Ulph 2006). Carraro and Siniscalco (1993) and Hoel and Schneider (1997) propose similar models in which
} 
Given this setup, it is clear the size of the coalition changes payoffs for both members and nonmembers. For an agreement to be self-enforcing the coalition must be stable such that member countries cannot do better by unilaterally withdrawing from the agreement (internal stability) and non-member countries cannot do better by unilaterally joining the agreement (external stability) (Rubio and Ulph 2006). The basic insight of the Barrett-type model is that self-enforcing IEAs can achieve extensive participation, but only when the gains from cooperation are small. ${ }^{14}$

A second strand of the literature models IEAs as repeated games. These games typically are infinitely repeating with an agreement reached in the first stage and sustained in following periods if punishment threats are credible (Barrett 1999, 2003). For punishment to be credible, an equilibrium agreement cannot be renegotiated if there is defection by any party (Farrell and Maskin 1989; Barrett 1999). Defection is detected without cost. Punishment, however, can be costly because if a member defects, all others abandon the agreement and lose the public good. ${ }^{15}$ Under this scenario, a player can defect from an agreement knowing that punishment is not individually rational and the equilibrium breaks down. To address this problem, Froyn and Hovi (2008) limit the number of nations that punish non-compliance to make punishment less costly and more credible, and hence, international environmental agreements more stable.

Much of the IEA literature focuses on whether a stable coalition forms, rather than on the structure of the coalition or on the nature of the outcomes. Some papers, however, investigate the coalitions that are possible. Barrett (2002) defines two general cases of "narrow but deep" and "broad but shallow" cooperation whereby a stable IEA is achieved with a few countries mitigating much or many countries mitigating little. Dellink and Finus (2012) and Finus and

coalition members exhibit Cournot behavior.

${ }^{14}$ This prediction is contrary to that made by Demsetz (1967) who argued, using transaction cost reasoning, that property rights institutions emerge when the net gains from defining them rise relative to the costs.

${ }_{15}$ Tarui et al (2008) examine cooperation in the management of renewable resources, where noncompliance is costly to observe. 
Pintassilgo (2013) allow for the formation of multiple, more homogeneous coalitions so that countries can find smaller coalitions that better align their interests and achieve broader mitigation through transfer payments. Asheim et al (2006) posit that more public goods could be provided by two regional coalitions of fewer participants than by one large agreement.

The IEA literature also examines uncertainty in mitigation benefits and costs. The literature generally is pessimistic about the impact of the resolution of uncertainty through learning on cooperation. One of the earliest papers to address this issue is by $\mathrm{Na}$ and Shin (1998). Within their model, countries cooperate when they are equally ignorant about expected benefits. New knowledge reduces uncertainty but also exposes differences in expected returns and results in the breakdown of cooperation. This finding is replicated in other work (Ulph and Ulph 1997; Ulph 1998; Ulph 2004; Kolstad 2007; Kolstad and Ulph 2008, 2009). The relationship between learning and cooperation depends on whether or not the coalition of countries is fixed. When a group of countries initially commits, learning bolsters cooperation by revealing collaborative benefits, and countries that did not join cannot subsequently do so. When the coalition has variable membership and forms each period, learning may result in less cooperation as countries act strategically when new information is disclosed (Ulph 2004; Kolstad and Ulph 2008).

Kolstad and Ulph $(2008,2011)$ examine the effects on cooperation of no learning, partial learning, and complete learning. No learning occurs when countries join and learn only after deciding on abatement. Partial learning occurs when countries learn the benefits of cooperation after joining, but before deciding on abatement. Complete learning occurs when countries learn the benefits prior to joining. Each has different implications for cooperation. Uncertainty with complete learning leads to larger membership, but lower aggregate abatement. Uncertainty with 
partial learning leads to lower membership and less abatement than the cases of no learning or complete learning.

Uncertainty and learning also raise a timing problem for each country. Should it adopt preemptive policies and invest in capital for mitigation or should it wait until more is known? There are two potential irreversibilities, one associated with cumulative externality effects and the other with sunk technology investments that could lead to a non-optimal capital stock. The response depends on relative costs that could be difficult to assess (Kolstad 1996a, 1996b).

The role of country heterogeneity in international environmental agreements is complex. Heterogeneity may lead to broader, more durable agreements, but with lower aggregate benefits (Carraro and Siniscalco 1993; Chander and Tulkens 1995, 1997). Barrett (2001) and Kolstad (2007) point out that agreement is particularly hard when there is substantial variation across countries with regard to the interpretation of uncertain benefits and costs of IEA membership. ${ }^{16}$ Differences across countries in estimated damages and discount rates limit cooperation and lower aggregate welfare benefits (Haag and Lagunoff 2007) or they reduce the size of the cooperating coalition (Hannesson 2010). On the other hand, heterogeneous damages can promote cooperation when heterogeneity allows for gains from trade and the use of transfer payments (Carraro and Siniscalco 1993; Barrett 2001; Asheim and Holtsmark 2009; Kolstad 2010; Dellink and Finus 2012; Finus and Pintassilgo 2013). For example, low-marginal damage or lowabatement cost countries could potentially receive transfer payments from high-damage, highcost countries to join collective efforts. This trade reduces abatement costs and creates a surplus to fund transfers (Barrett 2001, McGinty 2007). Heterogeneous levels of wealth and economic development across countries in the presence of preferences for the well-being of others, equity,

\footnotetext{
${ }^{16} \operatorname{Kolstad}(2007,1-2)$ notes that, due to uncertainty about the effects of climate change and hence, the benefits of immediate mitigation, the U.S. did not ratify the Kyoto Protocol, preferring to wait until there was more conclusive evidence. In contrast, the European Union concluded that something must be done before it is too late.
} 
and fairness also can facilitate cooperation through transfers and other concessions (Rose et al 1998; Fehr and Schmidt 1999; Kolstad 2011; Dellink and Finus 2012; Finus and Pintassilgo 2013).

Overall, the thrust of the IEA literature is that cooperation, even in simplified settings where countries are viewed as individual, rational actors is difficult and achievable only under specific conditions. The IEA literature does not, however, examine the institutional structure through which cooperation takes place nor the transaction costs encountered (Gilligan 2010).

It is plausible that transaction costs could be incorporated into a game-theoretic IEA model without adding so much complexity that the model becomes intractable. Even so, adding the details of the institutional setting, how it is put into place, and how it affects cooperation and outcomes is inherently challenging. A more expansive examination of cooperation to confront global environmental externalities reveals that where transactions costs are lower, collective action is possible and that where transaction costs are high, significant cooperation is less feasible.

A transaction costs approach recognizes that costs arise from the structure and process of the game itself. These affect coalition composition, timing, durability, and performance. Although the IEA literature points out that transfer payments may entice greater cooperation, it does not provide insight on how the additional costs of negotiating transfers will reduce the overall gains from cooperation and the likelihood of agreement. The key role of transaction costs in molding economic institutions and behavior is emphasized by Coase $(1960,1992)$ and Williamson $(1979,2010)$, and those costs affect international agreements.

Multilateral cooperation among sovereign nations is an inherently contractual procedure. Rents are created and costs are borne whenever behavioral constraints are agreed upon. 
International agreements implicitly assign those costs and benefits as property rights. Country leaders participate when it is in the interest of major constituents to do so. Countries are composed of varying interests who are affected in different ways from a different distribution of property rights. Accordingly, they organize and lobby to influence country positions in international negotiations and treaty compliance. Cooperation is not a single event, but can take many forms and occur at different times with important implications for the timing, extent, and duration of cooperative mitigation.

A transaction costs approach allows for more texture and detail in the institutional structure of the international agreement than is provided in the IEA literature. It examines the costs of aggregating disparate country interests into national positions and representing them in international cooperative institutions - treaties, governance structures, transfer mechanisms, and enforcement arrangements. It also analyzes how preference aggregation and bargaining among heterogeneous interests across countries influences outcomes. Transaction costs predict how uncertainty, differential preferences and perceptions, asymmetric information, and enforcement costs among heterogeneous parties determine the property rights that can be agreed upon. ${ }^{17}$

Thus far, there has been little analytical modeling of transaction costs in international environmental agreements. Krutilla and Krause (2010) provide an overview of some of the literature and insights for further modeling and testing. Systematic empirical analysis of the factors affecting international collaboration across settings also is very limited. Hence, this review suggests opportunities for research. Future work can take advantage of the over 700 international environmental agreements and informal conventions in Ronald Mitchell's (2012)

\footnotetext{
${ }^{17}$ Cooper (1989, 180-1) discusses the difficulties encountered in achieving successful international collective action to control infectious diseases, which took over 100 years to establish.
} 
database. ${ }^{18}$ Basic information on IEA agreements is provided by subject, date, membership, performance, secretariat websites, and relevant literature. With these data it is possible to analyze negotiations; identify the positions taken by country representatives; examine exchanges made; locate the parties in the coalition and those that did not join; show what actions were feasible and which ones were rejected; and to outline the distribution of costs and benefits.

In the absence of an existing conceptual/theoretical framework to guide the empirical analysis of transaction costs and multinational externality control, it is useful to briefly review the large literature on common-pool resource (CPR) where local actions to control CPR externalities occur without overarching formal enforcement as is the case with global CPRs, but with low transaction costs. This literature points out what is possible when transaction costs are minimal, and what happens for cooperation when transaction costs rise.

\section{Local Common-Pool Resources (CPRs) and Transaction Costs.}

The local CPR literature is extensive and generally reports success in controlling externalities. It includes case studies and experimental analyses that use the game theory of common property regimes as their theoretical framework (Ostrom 1990, 2000; ${ }^{19}$ Ostrom et al. 1994, 2002; Varughese and Ostrom 2001). Other work includes Acheson (1975, 1988, 2003); Wade (1988); Berkes et al (1989); Baland and Platteau (1996, 1997, 1998); Bardhan (2000); Dayton-Johnson (2000a, 2000b); Gardner et al. (2000); Chermak and Krause (2002); DaytonJohnson and Bardhan (2002); Acheson and Gardner (2005); Faysse (2005); Adhikari and Lovett (2006); Ruttan (2008); and Deacon et al. (2013). The empirical cases cover groundwater basins, communal irrigation systems, local forest lands, pastures, inshore or artisanal fisheries, and offshore regional fisheries.

\footnotetext{
${ }^{18} \mathrm{http}: / /$ iea.uoregon.edu/.

${ }^{19}$ For a concise summary of Ostrom's work and its impact see Bergstrom (2010).
} 
Conditions for successful collective action to reduce externality losses are generalized by Wade (1988, 215-16); Ostrom (1990, 88-102); Baland and Platteau (1996, 286-90); and Cox et al (2010). ${ }^{20}$ These conditions indicate low transaction costs: little scientific uncertainty; similar preferences and perceptions among the population; minimal asymmetric information; and widespread compliance. Uncertainty is low because the resource is well-understood, measureable, and boundable; there are past experiences with externality control; the response of the resource to cooperation is observable; and mitigation rents are appropriable. There are similar preferences and perceptions regarding the CPR problem because populations are small, socioeconomically homogeneous, characterized by trust, repeat exchange, and communication, and there is a proportionate sharing of mitigation benefits and costs to align incentives (Cox et al 2010, Table 4). Enforcement costs are lowered via restrictions on entry, use of monitors who are accountable to users, existence of institutions for arbitrating disputes and applying sanctions, and acceptance of local governance regimes by higher levels of government.

Although the literature centers on local CPRs, there is growing discussion on how the findings might be scaled up for addressing global externalities (Young 1994, 429-31; 2011, 6; Keohane and Ostrom eds 1995; Ostrom et al 1999; Cash et al 2006; McGinnis and Ostrom 2008, 189-211; O’Neill 2009, 11-15; Jaffe and Stavins 2010, 139-44; and Ostrom 2011, 2012). Scaling up in this literature, however, often is presented quite abstractly. Accordingly, it is not immediately obvious how to apply the lessons of local CPRs to global externality control.

It is nevertheless possible to illustrate more specifically how the insights from successful local CPR management can be applied to a larger level. This involves one of two approaches: (i)

\footnotetext{
${ }^{20}$ Because this research is interdisciplinary, encompassing a wide variety of analytical approaches, there have been efforts to provide a unifying structure for research (Agrawal 2001; Ostrom 2009; Poteete et al 2010; and the dataset on CPR cases maintained at the Center for the Study of Institutional Diversity, Arizona State University: http://seslibrary.asu.edu/.)
} 
identifying settings where local or regional CPR management importantly affects the performance of wider mitigation; and (ii) examining local and regional CPR cases where transaction costs are higher, undermining efforts to assign property rights to control the externality. Examination of such cases yields implications for the effect of transaction costs on the success of broader collective action efforts.

Research along these lines provides intuition for scaling the lessons of local CPRs to international ones. Investigators can draw upon the dataset on CPR cases at the Center for the Study of Institutional Diversity, Arizona State University, ${ }^{21}$ and the International Environmental Agreements Database Project at the University of Oregon. ${ }^{22}$ The four testable implications regarding uncertainty, varying preferences and perceptions, asymmetric information, and enforcement presented in Section I can then be used to analyze not only local CPR cases but also to explain the diversity of international cooperative outcomes.

In terms of the first approach that points to linkages between local CPR management and the success of more global efforts, consider the United Nations initiative for Reducing Emissions from Deforestation and Forest Degradation in Developing Countries, (UN-REDD), launched in $2008 .{ }^{23}$ Some $20 \%$ of annual GHG emissions may come from deforestation; reductions in timber harvest can therefore play an important abatement role. UN-REDD is an offset scheme for carbon markets in which emitters in industrialized countries pay for tropical forest protection and gain carbon credits at lower cost than with direct abatement. The success of global mitigation through forest protection, however, depends upon local cooperation and program design that reflects existing communal CPR management practices. Many tropical forests are inhabited, are vital sources of local goods and services, and are administered by informal community rules

\footnotetext{
${ }^{21}$ http://seslibrary.asu.edu.

22 http://iea.uoregon.edu/.

23 www.un-redd.org/.
} 
(Poteete and Ostrom 2004; Gibson et al 2005; Alston and Andersson 2011; Alston et al 2013; Pfaff et al 2013). Effective carbon sequestration land-use controls require aligning broad mitigation objectives with the incentives of residents and taking advantage of their specific knowledge.

Alston and Andersson (2011) describe a case where this is not happening, potentially undercutting GHG abatement goals. These authors point out that external regulation as part of REDD can make local property rights less secure and raise suspicion among inhabitants who have little experience with outsiders and have different preferences and perceptions over resource use. Under these circumstances, local users have less incentive to cooperate with REDD's forest-protection policies. To enlist support, Alston and Andersson recommend surveying forest users and their property institutions as a first-order requirement along with collecting baseline forest biomass and using indigenous organizations for the distribution of REDD funds and contract enforcement. ${ }^{24}$

Similarly, because international mitigation can disrupt indigenous CPR practices, Busch (2013) argues that payments to native populations for forest and biodiversity protection should be structured as compensation for their opportunity costs rather than as abstract carbon-offset fees. Such an approach makes it clear who should receive payments, specifies amounts necessary, and helps ensure that REDD's activities are sensitive to existing informal property rights.

To illustrate the second approach—examining the impact of higher transaction costs on local and regional CPR management and their implications for broader mitigation - two cases are summarized from U.S. economic history. In these examples, the costs of defining property

\footnotetext{
${ }^{24}$ Plantinga and Richards (2010) discuss program design for forest carbon sequestration and emphasize blending projects with any post-Kyoto international mitigation policies.
} 
rights are greater due to more scientific uncertainty, different perceptions and preferences, asymmetric information, and higher enforcement costs. The cases also have longitudinal and cross-sectional empirical detail that often is not available in the local CPR literature. This data advantage reveals the benefits of analyzing economic history to identify the determinants of collaboration in externality mitigation. ${ }^{25}$

\section{U.S. Oil and Gas Exploration and Production.}

Oil and gas reservoirs in the U.S. are CPRs exploited by multiple production lease holders, where open-access losses resulting from competition for resource rents have been a long-standing concern. Oil-producing firms gain use of reservoirs through leases granted by surface land owners. Where surface ownership is fragmented, many firms compete for the same oil and gas because the hydrocarbons migrate within the reservoir across lease lines. Hence lease holders have incentives to rapidly drill wells and drain. In 1914 the U.S. Bureau of Mines estimated costs of excessive capital at a quarter of the value of total U.S. production. In 1926 the Federal Oil Conservation Board estimated recovery rates at $20-25 \%$ as compared to $89-90 \%$ with more restrained extraction (Libecap and Smith 2002, S592-3). On the giant East Texas field the American Petroleum Institute in 1937 estimated the capital costs of unnecessary wells at over \$200 million--over \$3 billion in 2011 dollars (Libecap and Wiggins 1985, 694). The Prudhoe Bay reservoir in Alaska, discovered in 1968 and more than double the size of the East Texas field, began producing in 1977, but went into decline in 1988, not because of waning deposits, but because of competitive extraction of natural gas that could have forced out additional petroleum (Libecap and Smith 1999, 545).

\footnotetext{
${ }^{25}$ For example, when property rights are not well defined and new entry is not controlled, holdout is possible. This is referred to as the anti-commons (Heller 1998). Rosenthal (1990) makes use of extensive archival data on collaborative efforts to develop irrigation systems in France and their effects on agricultural output in the $18^{\text {th }}$ and $19^{\text {th }}$ centuries. He shows that the French revolution was necessary to redefine property rights and strengthen the power of eminent domain against holdout in order to lower transaction costs.
} 
CPR management to control technological externalities occurs at the field, state, and interstate levels. Lease holders attempt to define property rights in the reservoir through output prorationing, assigning shares in a field-wide production unit, or lease consolidation. As the losses above indicate, however, their efforts have been surprisingly incomplete due to transaction costs. Scientific uncertainty about the resource and the impact of competitive production from separate leases impedes agreement. Wiggins and Libecap $(1985,372-76)$ model the problem of uncertainty. Reservoirs are not uniform and engineering knowledge of key parameters affecting the value of individual leases and their contribution to production externalities is limited. These circumstances make it difficult for lease owners to agree either on lease sales for consolidation or on unitization whereby a single firm develops the oil field and distributes the rents as unit shares, thereby avoiding competitive extraction. ${ }^{26}$ Wiggins and Libecap $(1985,377-83)$ examine detailed unitization share negotiations for 7 fields in Texas and New Mexico discovered between the 1930s and 1950s and find that time to settlement ranged from 4 to 9 years. One unit agreement required 6 years of negotiations and at least 58 rounds of voting on different property rights assignments. Despite losses from competitive production, consolidation of major Prudhoe Bay leases took 32 years (Libecap and Smith 1999; 2001; 2002, S593-72002).

Heterogeneous perceptions of externality costs among lease owners also hinder agreement. Leases above the deepest part of the reservoir with the largest per-acre production potential and situated to capture subsurface oil flows are less affected by the externality than are leases located on the field periphery. Wiggins and Libecap $(1985,376)$ show that strategicallypositioned lease owners holdout in unitization negotiations, and disagreements on lease values block consensus on transfers to overcome opposition. Asymmetric information further raises

\footnotetext{
${ }^{26}$ Crothers and Nelson (2007) and Kaffine and Costello (2010) examine unitization in other natural resources to avoid open-access losses.
} 
transaction costs. Lease potential is revealed in public and private information (Wiggins and Libecap 1985, 370-5). Public information includes cumulative oil production and lease surface size, and private information includes the extent of subsurface deposits and hydrocarbon flows. Disagreement on private information and its interpretation for lease values delays agreement on assigning property rights in the field. Finally, there are problems of enforcement and new entry. State regulation of lease production occurs via annual output caps (Libecap and Smith 2002, S594-5), but lease holders have different incentives to comply. Small lease owners who internalize fewer of the field-wide losses often cheat. For example, in 1931, rampant violation of output controls by numerous small producers led the Governor of Texas to temporarily place the East Texas field under martial law (Wiggins and Libecap 1987, 4 and Libecap 1989b, 838).

In addition to efforts at controlling externalities at the field level, there also have been interstate actions to limit the dissipation of pecuniary rents, but these cooperative actions have also been thwarted by high transaction costs. The major oil-producing states coordinated output for 40 years from 1933-1972 through the Interstate Oil Compact Commission (IOCC) that provided a recommended annual aggregate production cap distributed across states (Libecap 1989b, 834). Cartelization, however, remained only loosely centralized and it was not structured in a manner to maximize rents. In this instance, uncertainty was not a major problem. The benefits of higher cartel prices were clear and more rents could have been earned and shared, had the IOCC been delegated the authority to fix state output levels. There were, however, differential preferences and perceptions across the states regarding the costs and benefits of cooperation. Even though Texas was by far the largest producer, it did not disproportionately reduce its output to fix prices. Moreover, oil-producing states were unwilling to cede control over such a critical industry to an outside interstate agency or to the federal government to better 
facilitate cartelization. Instead, each state regulatory agency determined state production policies in response to internal political pressures. The Texas Railroad Commission exempted influential owners of high-cost stripper wells. Reducing their production would have been the efficient way to meet the state's quota. Instead, Texas imposed regulation on low-cost firms from out of state (Libecap and Wiggins 1984, 91-6; 1985, 710-12).

Incomplete local, state and interstate regulation of competitive oil output has taken place within one country with reasonably accurate information on aggregate externality losses, production, and compliance, all of which could have promoted greater cooperation. The fact that agreement has not occurred shows how transactions costs limit collaborative mitigation efforts even under comparatively favorable circumstances. It also illustrates how the internal politicaleconomy determines the regulatory discretion that can be delegated to outside bodies. These issues are even more problematic when confronting broader environmental externalities across nations where the benefits of cooperation are less obvious and less appropriable by critical within-country constituencies. Such factors are not examined in the current IEA literature. Further, Libecap and Smith (2002) show that more cooperative externality mitigation has taken place as resource values have risen, counter to the IEA argument that cooperation is greatest when the gains are small (Barrett 1994).

\section{The Maine Lobster Fishery.}

This second CPR case is instructive because of the lessons revealed when external formal rules are imposed on local property rights and management practices. Such extensions of regulation are inherent in international coordination to address broad externalities. When transaction costs are high, regulations can be resisted by local parties because a cooperative arrangement with regulators cannot be reached. In the case of the Maine lobster fishery, local 
fishers established informal property rights and harvest supervision with generally favorable outcomes beginning in the late $19^{\text {th }}$ century (Acheson 1988; Acheson 2003, 1, 17-18, 57-145, 217-221; Acheson and Gardner 2005). Conflicts arose when these practices were viewed as inadequate and the fishery was placed under formal federal regulation in 1977 by the Fisheries Conservation and Management Act of 1976 (FCMA, P.L. 94-265). Local fishers and federal regulators within the National Marine Fisheries Service (NMFS), however, did not agree on proposed stricter federal harvest controls.

Stock uncertainty, asymmetric information, and differential perceptions and preferences for more restrictive regulation led to conflicting views between fishers and NMFS officials. The former relied upon local knowledge and historical environmental conditions whereas the latter relied upon formal modeling and simulations that suggested that existing harvests were unsustainable. Neither party could successfully convey their assessment of stock status to the other party and achieve cooperation. An impasse ensued for nearly 20 years. In 1995, regulatory authority was delegated to the industry and the states to devise a regional lobster management plan, which was implemented in 1997 (Acheson, 2003 169-179, 182). Under the new institutional arrangement, the parties had similar information, modeling approaches, views of the fishing externality, and preferences for addressing it. Hence, they were better able to agree upon stock conditions and the regulations to be imposed.

At the heart of this example is a scientific dispute concerning the effect of production externalities relative to natural stock fluctuation. When scientific evidence regarding the externality is inconclusive or its implications differentially interpreted, uncertainty about mitigation rents reinforces differential preferences for taking action. Transaction costs therefore rise. In other fisheries conflicts arise for very similar reasons (Normile 2009; Polacheck 2012). 
As the range of environmental externalities expands there will be more heterogeneous assessments of problems and of how to confront them. Options exist, however, for lowering transaction costs including investment in new knowledge that reduces uncertainty in the level and distribution of benefits and costs; provision of neutral sources of information to reduce asymmetries (these may or may not involve regulatory agencies); distribution of transfer payments to offset differential preferences for collaborative abatement and varying opportunity costs; and objective, reliable enforcement.

The effects of new information on uncertainty and transfers to confront heterogeneous preferences have been examined in the IEA literature (Carraro and Siniscalco 1993; Barrett 2001; Kolstad and Ulph 2008, 2009), but these relationships have not been systematically analyzed empirically. There is potential for further analysis of how varying transaction costs affect cooperative outcomes. The following section discusses several examples of multilateral externalities, moving from low to high transaction cost cases. These cases illustrate how the four testable implications outlined in Section I regarding uncertainty, varying preferences and perceptions, asymmetric information, and enforcement costs influence property rights definition and the likelihood that global environmental externalities are addressed.

\section{Global Externalities: The Implications of Scientific Uncertainty, Different Preferences and Perceptions, Asymmetric Information, and Enforcement.}

Global environmental externalities are those that arise when parties in one country endanger a widely-valued resource, such as a site with an exceptional ecosystem or a distinctive population of plants, animals, birds, or fish, and when parties from many nations deplete or depredate a broader resource, such as migratory fish stocks or the atmosphere. In either case mitigation requires multinational cooperation. Table 1 lists the global environmental externality cases examined in this section according to the transaction costs of property rights definition, 
ranging from low to medium to high. There is a transaction-cost continuum and the cases

presented here illustrate what international collaboration is possible along that continuum.

The examples in column (1) demonstrate that when low transaction costs are low, cooperation on property rights is straightforward; those in column (2) involve higher transaction costs because more countries are involved, but cooperation remains possible; and those in column (3) have much higher transaction costs due to scientific uncertainty, varying preferences and perceptions for externality mitigation, asymmetric information, and high enforcement costs. In these cases agreement on property rights and cooperation has not been successful. These results align with the testable implications outlined in Section I.

Table 1: Categorizing Transaction Costs in Addressing Global Environmental Externalities

\begin{tabular}{|c|c|c|c|}
\hline & $\begin{array}{c}\text { (1) } \\
\text { Low Transaction } \\
\text { Costs: Externality } \\
\text { Mitigation occurs } \\
\text { within in a Single } \\
\text { Country }\end{array}$ & $\begin{array}{l}\text { (2) } \\
\text { Medium Transaction } \\
\text { Costs: Externality } \\
\text { Mitigation occurs across } \\
\text { Selected Countries }\end{array}$ & $\begin{array}{l}\text { (3) } \\
\text { High Transaction Costs: } \\
\text { Externality Mitigation } \\
\text { occurs across Multiple } \\
\text { Countries }\end{array}$ \\
\hline Examples: & $\begin{array}{c}\text { Globally valued } \\
\text { ecosystems: National } \\
\text { Parks }\end{array}$ & $\begin{array}{c}\text { Convention on } \\
\text { International Trade of } \\
\text { Endangered Species } \\
\text { (CITES); Montreal } \\
\text { Protocol on Substances } \\
\text { that Deplete the Ozone } \\
\text { Layer }\end{array}$ & $\begin{array}{c}\text { International Commission } \\
\text { for the Conservation of } \\
\text { Atlantic Tunas (ICCAT); } \\
\text { Kyoto Protocol to Control } \\
\text { Greenhouse Gas (GHG) } \\
\text { Emissions }\end{array}$ \\
\hline Scientific Uncertainty & Low & Medium & Medium to High \\
\hline $\begin{array}{c}\text { Varying Perceptions and } \\
\text { Preferences }\end{array}$ & $\begin{array}{c}\text { Limited: Addressed } \\
\text { through Transfers }\end{array}$ & $\begin{array}{l}\text { Limited to Medium: } \\
\text { Addressed through } \\
\text { Transfers }\end{array}$ & $\begin{array}{c}\text { High involving Populations } \\
\text { in Many Countries. } \\
\text { Transfers incomplete. }\end{array}$ \\
\hline Asymmetric Information & Low & Low to Medium & $\begin{array}{l}\text { High in Contribution to the } \\
\text { Externality, Mitigation } \\
\text { Response, and Compliance }\end{array}$ \\
\hline $\begin{array}{l}\text { Enforcement Costs and } \\
\text { New Entry Potential }\end{array}$ & Low & Low to Medium & High \\
\hline
\end{tabular}

\section{Category (1) Examples: National Parks.}

Biodiversity, unique habitats, and plant and animal species are valued by many parties globally, particularly within developed countries. The scientific benefits of reserving particular 
sites are typically known because of extensive studies and observation by researchers and wildlife advocates from western economies. Locations and species at risk, however, often are in developing regions where property rights are unclear or not enforced and where local preferences for resource use do not include biodiversity and habitat protection to the same degree as desired elsewhere. For these reasons, critical, vulnerable resources are exploited more intensely than is preferred by parties in developed countries who lose value or rents unless constraints on access and use are implemented. Different perceptions raise transaction costs, and agreement on property rights requires transfers.

The demanders of property rights are parties from high-income, developed countries who place importance on site protection. Demanders assemble as interest groups to lobby country leaders to support boundary designation and enforcement, provide subsidies for operation, and make payments to those who no longer have the same right of entry or use. The supply of property rights is determined by the international treaties reached with developing-country officials who define and enforce national park borders in exchange for compensatory payments and funding for operations costs. Because directly affected populations are limited and are relatively homogeneous - often indigenous herders, farmers, and hunters - opportunity costs can be determined at low cost and the necessary transfers are small. In some cases, indigenous occupants have not been organized or recognized politically so that offsetting their costs has not played a major role in multinational negotiations.

Globally, there are nearly 7,000 national parks that the International Union for Conservation of Nature (IUCN) classifies as Category II protected areas, and most are in lessdeveloped regions of the world. The IUCN is a global environmental organization made up of representatives of governments, international organizations, and environmental NGOs that 
establishes and monitors national parks. The organization, founded in 1948 initially as the International Union for the Preservation of Nature, ${ }^{27}$ is funded by contributions from developed countries, such as the Ford Foundation. Table 2 lists four representative national parks established in the $20^{\text {th }}$ century and the types of transaction costs encountered.

Table 2: National Parks to Protect Globally-Valued Ecosystems

\begin{tabular}{|c|c|c|c|c|}
\hline National Parks & $\begin{array}{c}\text { Years } \\
\text { Established }\end{array}$ & $\begin{array}{c}\text { Property Rights } \\
\text { Demanders and Funds } \\
\text { Providers } \\
\end{array}$ & $\begin{array}{l}\text { Property } \\
\text { Rights } \\
\text { Suppliers } \\
\end{array}$ & Transaction Costs \\
\hline $\begin{array}{c}\text { Manú, Peru } \\
\text { Kruger, South Africa } \\
\text { Nairobi, Kenya } \\
\text { Serengeti, Tanzania }\end{array}$ & $1926-1973$ & $\begin{array}{l}\text { Citizens of developed } \\
\text { countries; NGOs; World } \\
\text { Bank, UN, and other } \\
\text { international agencies }\end{array}$ & $\begin{array}{l}\text { Colonial and National } \\
\text { Governments as } \\
\text { defined by } \\
\text { International } \\
\text { Agreements }\end{array}$ & $\begin{array}{c}\text { Different preferences } \\
\text { of occupants; } \\
\text { Displacement; } \\
\text { Dispute over transfer } \\
\text { amounts; } \\
\text { Enforcement }\end{array}$ \\
\hline
\end{tabular}

The Manú National Park or Biosphere Reserve was created in 1973 by the Peruvian Government to protect unique biological and ecological resources. It is the largest national park in Peru, covering a total area of $18,811 \mathrm{~km}^{2}$ with one of highest levels of biodiversity of any park in the world. Within its boundaries are more than 15,000 plant species, over 1,000 bird species, and one of the highest concentrations of land vertebrates in Latin American. Protection of this remote reserve was sought by researchers and environmental groups in the U.S. In return for restrictions on occupancy and land use, the government of Peru receives financial support from the World Wildlife Fund, U.S. Debt-for-Nature Swaps, and other international organizations. Indigenous inhabitants remain in the park and given limited numbers and traditional use practices their continued occupancy is consistent with park objectives (Shepard et al 2010). ${ }^{28}$ Overall, the transaction costs behind designation of Manú were low. The scientific value of the

\footnotetext{
${ }^{27}$ www.iucn.org.

${ }^{28}$ Funding also is from the UN Development Program (UNDP), the World Bank, International Bank for Reconstruction and Development (IBRD), and the Global Environment Facility (GEF), www.thegef.org/. The park is described in Olson et al (2001).
} 
site was understood; demanders of property rights for the reserved area were organized; the affected population was small; transfers were made; and boundary infringement limited.

Kruger National Park was established in 1926 to safeguard exceptional African wildlife species. Kruger is one of the largest reserves in Africa, covering an area of $19,633 \mathrm{~km}^{2}$ and has the most species of large mammals in the continent. The initial transaction costs of property rights definition to the protected area were minimal because the park was established under colonial rule at the request of organized British citizens, who valued the distinctive wildlife in the reserve. The indigenous native population participated little in original boundary and land use concessions (Mabunda et al. 2003). Subsequent property rights negotiations, however, have involved representatives of the South African Government and those of developed countries to incorporate broader conservation principles of the IUCN, the Convention on Biological Diversity of $1992,{ }^{29}$ and the Convention on the International Trade in Endangered Species of Wild Fauna and Flora. Funding for operations and transfer payments are provided by the UN Development Program and the Global Environment Facility, ${ }^{30}$ environmental NGOs, and eco-tourism.

Similarly, Nairobi National Park was founded in 1946 under colonial rule at the behest of British conservationists who valued the site adjacent to the city of Nairobi because of its rich, accessible animal populations. The park covers an area of $117.21 \mathrm{~km}^{2}$ and has diverse wildlife, including a rhinoceros sanctuary. Establishing the park displaced the resident Maasai population (Prins and Grootenhuis 2000). Foreign tourism, the Kenyan government, and international environmental organizations provide funding for operations and site protection.

A similar history lies behind the Serengeti National Park, created in 1940 at the urging of members of a British group, the Society for the Preservation of Fauna of the Empire (Child and

\footnotetext{
${ }^{29}$ www.cbd.int/convention/.

${ }^{30}$ www.thegef.org/.
} 
Lyman 2005). The park covers $14,763 \mathrm{~km}^{2}$, including much of the Serengeti ecosystem, and is home to a wide array of wildlife. Compensation comes from tourism, the World Bank, the Global Environmental Facility, and other NGOs. When the park was set up native inhabitants were relocated; there are continuing negotiations over compensation (Sinclair 1995; Polasky et al 2008).

\section{Category (2) Examples: Convention on International Trade of Endangered Species (CITES) and the Montreal Protocol on Substances that Deplete the Stratospheric Ozone Layer}

The next examples of global externalities involve somewhat higher transaction costs.

These two examples are representative of the most common international environmental agreements (Mitchell 2012). Compared to Category (1) cases, cooperation of multiple countries with more varied populations is required. Category (2) international environmental agreements are nevertheless common because there are reasonably low transaction costs in property rights definition. In terms of the four implications outlined in Section I, scientific uncertainty is limited; differential preferences and perceptions of the externality between parties in developed countries and those in developing ones are overcome through transfers; asymmetric information is not a major obstacle because the externality itself and the contributors to them are observable; and enforcement is feasible through standard monitoring institutions and technologies.

Convention on International Trade in Endangered Species (CITES).

CITES was initiated in 1963 and implemented in 1975. As of May 2013, 178 nations had ratified the Convention. ${ }^{31}$ Its objective is to protect endangered animal and plant species by reducing their exploitation value through international trade restrictions. The implementation of CITES trade constraints generally proceeds as follows. Citizens of developed countries, multinational corporations, and international conservation NGOs lobby for trade limits and

\footnotetext{
${ }^{31}$ www.cites.org/eng/disc/parties/.
} 
contribute funding to the CITES Trust Fund (Reeve 2002). ${ }^{32}$ In response, representatives of developing countries where many endangered species are at risk consider trade policies that vary according to CITES listings in three appendices: Appendix I is the strictest, whereby trade in a wild species is prohibited; Appendix II is for species-at-risk, but not immediately threatened, whereby international trade is monitored via export permits; and Appendix III has the loosest trade controls for species that are locally at risk, but not so elsewhere (Gehring and Ruffing 2008, 124-36).

A CITES listing can be proposed by any signatory party at a Conference of Parties (COP) meeting, whether or not they represent countries with resident species' populations. The trade constraints imposed, the compensation provided to designated parties, and enforcement determine the property rights defined by CITES listings. Considerable negotiations may be necessary as indicated in the COP meeting summaries ${ }^{33}$ Signatory countries can opt out of a listing. Incentives for compliance are provided through transfer payments, and enforcement is through monitoring, media reports of trade violations, and external political pressure on noncomplying national leaders to carry out treaty provisions.

As with national parks, country residents that are directly affected may or may not be represented in property rights assignments. Possingham et al. (2002) point out that a CITES listing can paradoxically threaten a species' survival if host country inhabitants are not compensated for the constraints imposed upon them and have different assessments of its status than do representatives of developed countries who propose listing (Bulte and van Kooten 1999, 453-4; Gehring and Ruffing 2008, 135; Missios 2004). ${ }^{34}$ Different perceptions and preferences

\footnotetext{
32 http://www.cites.org/eng/disc/fund.php.

33 These are found at http://www.cites.org/eng/cop/index.php.

${ }^{34}$ A similar point is made by Lueck and Michael (2003) who argue that the U.S. Endangered Species Act had a negative impact on endangered red-cockaded woodpeckers because enforcement of the law created an incentive for
} 
raise transaction costs. For instance, the ban on ivory trade to protect threatened African elephant populations was proposed in 1989 at COP 7 meeting among representatives from the U.S., other developed countries, and environmental NGOs. Listing was resisted by delegates from southern African countries led by Zimbabwe, who claimed that their elephant populations were not at risk and attempted to halt Appendix I listing at COP 8 meeting in 1992 (Barbier et al 1990, Bulte and van Kooten 1999, Kremer and Morcom 2000). Although these delegates were not successful, they continued to lobby and eventually achieved adoption of stricter Appendix I listing criteria and exemptions for specific populations at the 1994 COP 9 meeting (Gehring and Ruffing 2008, 130). Although CITES remains popular internationally there is considerable debate as to whether trade bans are an effective way to protect endangered species (Brown and Layton 2001; Horan and Shogren 2003; Fischer 2004; and Bulte and Barbier 2005).

The Montreal Protocol on Substances that Deplete the Ozone Layer.

The excessive release of chlorofluorocarbons (CFCs) and related substances creates a serious global externality that thins the stratospheric ozone layer that blocks solar ultraviolet radiation. Such radiation is especially harmful among Caucasian populations in northern latitudes who have a higher incidence of skin cancer. Ultraviolet radiation also has damaging effects on plant and marine life (Barrett 2005, 1-3, 7, 361; 2007, 75-84; Dimitrov 2006, 58-60). Accordingly, the main demanders of mitigation property rights are citizens of the U.S. and Western Europe, where most CFC production has taken place and where there are appropriable private benefits from broad externality alleviation. Indeed, Murdoch and Sandler (1997) view the phase out of CFCs by the U.S. as an example of private provision of a public good because of the extent to which the U.S. was able to capture the benefits of its own abatement activities. The

land owners to change their timber harvest practices. 
major international bargaining issue involved enticing cooperation of less-developed countries in bans on new production and trade in CFCs through transfers of funds and technologies.

The literature on negotiations among country representatives leading to the Montreal Protocol of 1987 is unusually large, allowing for a better understanding of the transaction costs encountered, how they were overcome, and how the negotiations influenced the agreement that finally emerged. Most of the empirical detail concerns the evolution of scientific knowledge; adoption of substitute chemicals; bargaining between politicians and industry representatives within the U.S. and western Europe; negotiations among U.S. and western European officials and representatives of transitional economies in Eastern Europe and developing countries over transfer payments and preferential treaty provisions; and the effects of subsequent CFC control on the stratospheric ozone layer. Representative work on the Montreal Protocol includes Nangle (1989, 531-43); Benedict (1991); Enders and Porges (1992); Ling (1992); Litfin (1994); Hollick and Cooper (1997, 157); United Nations Ozone Secretariat (1995, 1998); Beron et al (2003); Auffhammer et al (2005); Barrett (2005, 221-37; 346-51); Dimitrov (2006, 53-57); and Victor (2011, 43-6, 89).

Concern about the externality in the U.S. followed Molina and Roland's (1974) and Stolarski and Cicerone's (1974) hypothesized linkages between CFCs and thinning of the ozone layer. The U.S. unilaterally banned CFC-based aerosol sales in 1978. International negotiations followed the discovery of on an expanding Antarctic ozone "hole" and the development of lowcost CFC alternatives that reduced the cost of CFC phase out. The first major multinational agreement was the 1985 Vienna Convention for the Protection of the Ozone Layer (Vienna 
Convention for the Protection of the Ozone Layer, May 2, 1985, Treaty Doc. No. 9, $99^{\text {th }}$ Congress $1^{\text {st }}$ Sess., 1985). It was followed by the 1987 Montreal Protocol..$^{35}$

Differential perceptions and preferences for mitigation between representatives of northern developed countries and those from less-developed tropical countries were the primary sources of transaction costs. In tropical regions the externality was seen as less harmful, and CFCs were useful for low-cost refrigeration and industrial solvents. These differing views are reflected in cross-country patterns of participation, treaty ratification, and transfer payments. In the initial Montreal negotiations, 22 of the 50 countries whose representatives participated were from developed countries and $86 \%$ of them signed. In contrast, only 19 developing-country representatives were involved and $47 \%$ signed. The remaining representatives were from transitional economies. As financial and technological transfers were expanded for developing countries, adoption spread. Under the notion of "common but differentiated responsibilities" less-developed countries were allowed 10 years more than developed countries to reach lower production targets. The Multilateral Fund (MLF) and the Global Environmental Facility were established to provide financial and technical assistance for the gradual elimination of CFCs and HCFCs (hydro chlorofluorocarbons), chemicals that are less toxic to the ozone layer than CFCs and also are used as inexpensive refrigerants. Through 2012, approximately $\$ 2.8$ billion has been disbursed from the MLF to 140 developing countries with by far the largest amounts going to India and China. ${ }^{36}$ Most contributions to the MLF have come from northern latitude countries-Canada, France, Germany, Italy, Japan, Russia, U.K., and the U.S. ${ }^{37}$ CFC production has plummeted under the Protocol. HCFCs, however, remain problematic, as shown in Figure 1, with

\footnotetext{
35 ozone.unep.org/new_site/en/montreal_protocol.php.

${ }^{36}$ www.worldbank.org/mp/publications; www.unep.org/ozone. By 2012 China had received \$930 million and India \$248 million. Mexico and Brazil followed with \$100 million and \$92 million --Julia Anne Dearing, Information Management Officer, Montreal Protocol Multilateral Fund Secretariat, jamdearing@unmfs.org.

${ }^{37}$ Fund sources are listed in http://www.multilateralfund.org/67/English/1/6739.pdf).
} 
most production coming from China and India. ${ }^{38}$ Figure 2 traces MLF payments to China and India, the two largest recipients, and their total production of HCFCs. Figure 3 tracks the size of the ozone hole, indicating stability and some recent decline in area.

Figure 1: Total CFC and HCFC Production
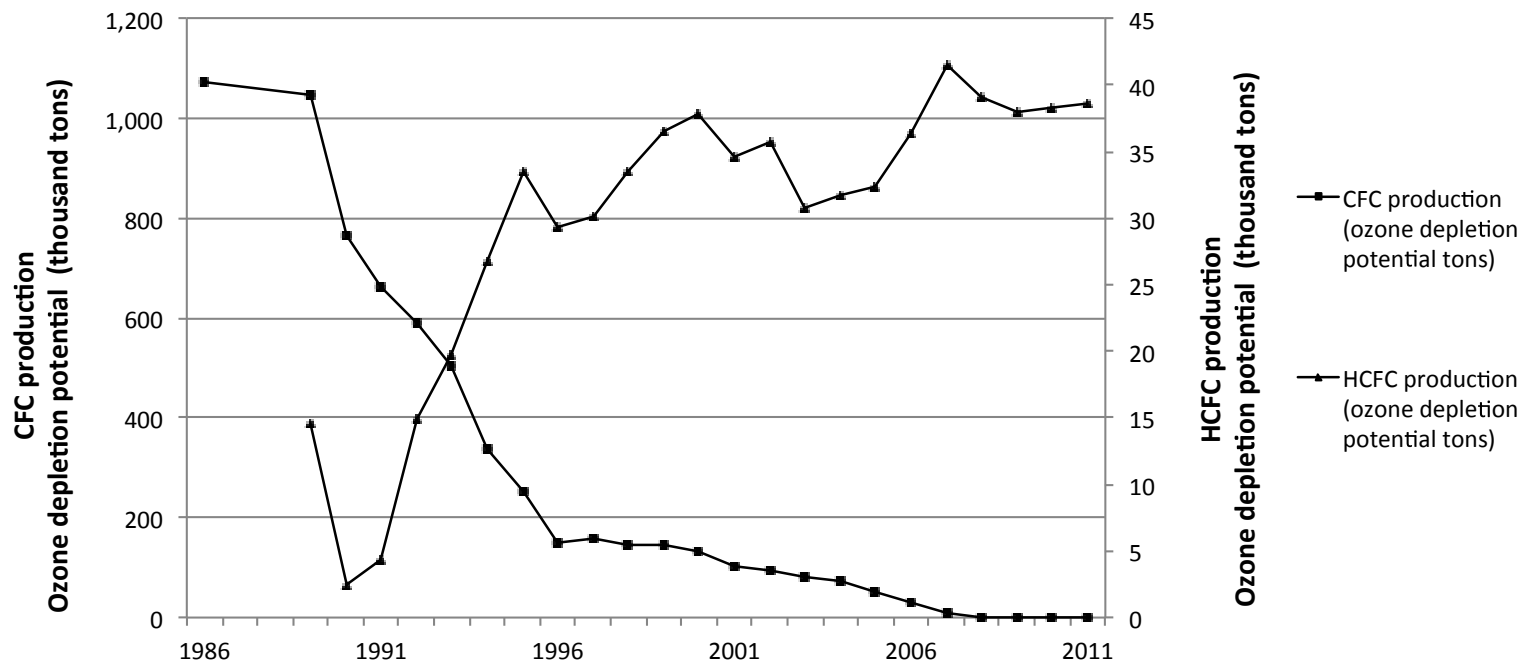

Source: http://ozone.unep.org/new_site/en/ozone_data_tools_access.php. Data compiled by Annex Group A/I (CFCs) and $\mathrm{C} / \mathrm{I}$ (HCFCs) for all countries.

http://web.worldbank.org/WBSITE/EXTERNAL/TOPICS/ENVIRONMENT/EXTTMP/0,,contentMDK:21795271 menuPK:5079015 pagePK:148956 piPK:216618 theSitePK:408230,00.ht. The Montreal Protocol and compliance with it are addressed in Velders et al (2007) and the United Nations Ozone Secretariat (2010). 
Figure 2: HCFC Production and Multilateral Fund Distributions in China and India

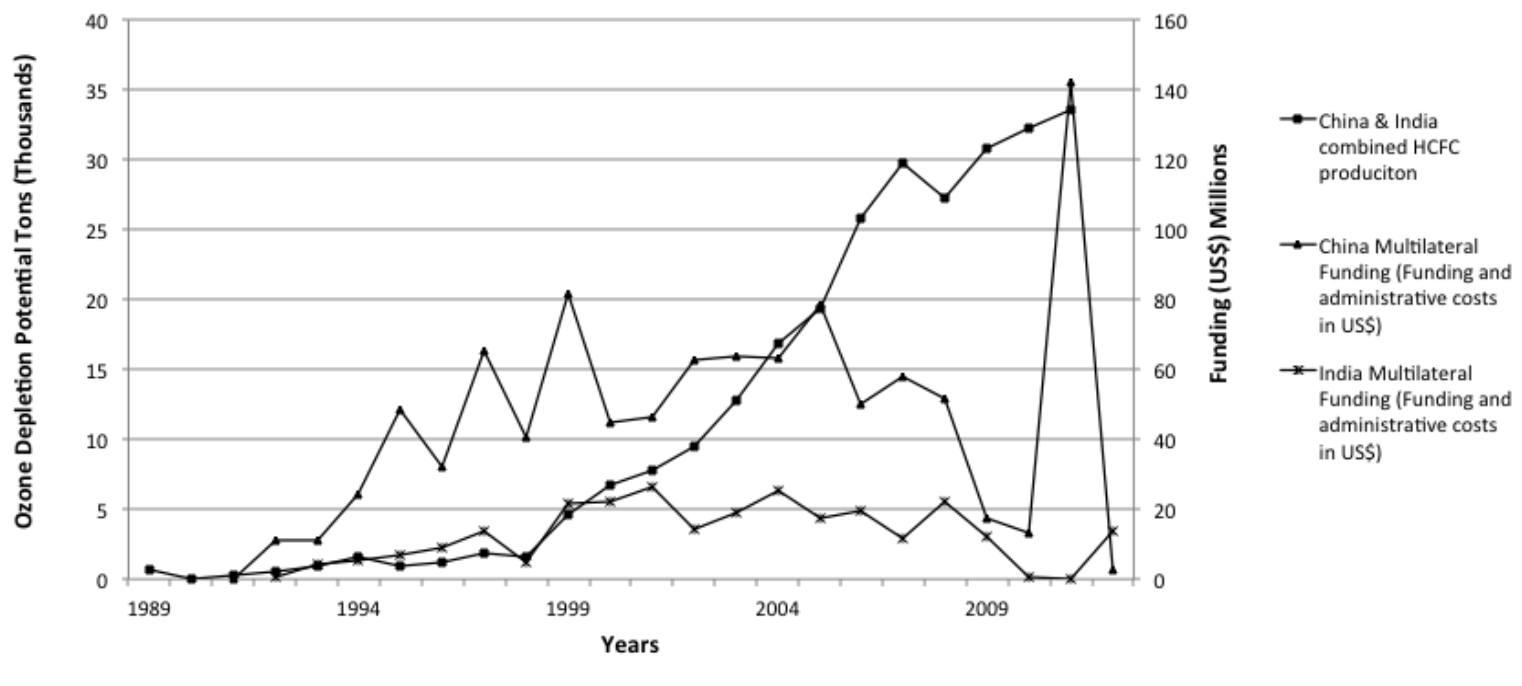

Source: Ozone: http://ozone.unep.org/new_site/en/ozone_data_tools_access.php; Data provided by Julia Anne Dearing, Information Management Officer, Montreal Protocol Multilateral Fund Secretariat, jamdearing@unmfs.org.

Figure3: Ozone Hole Area

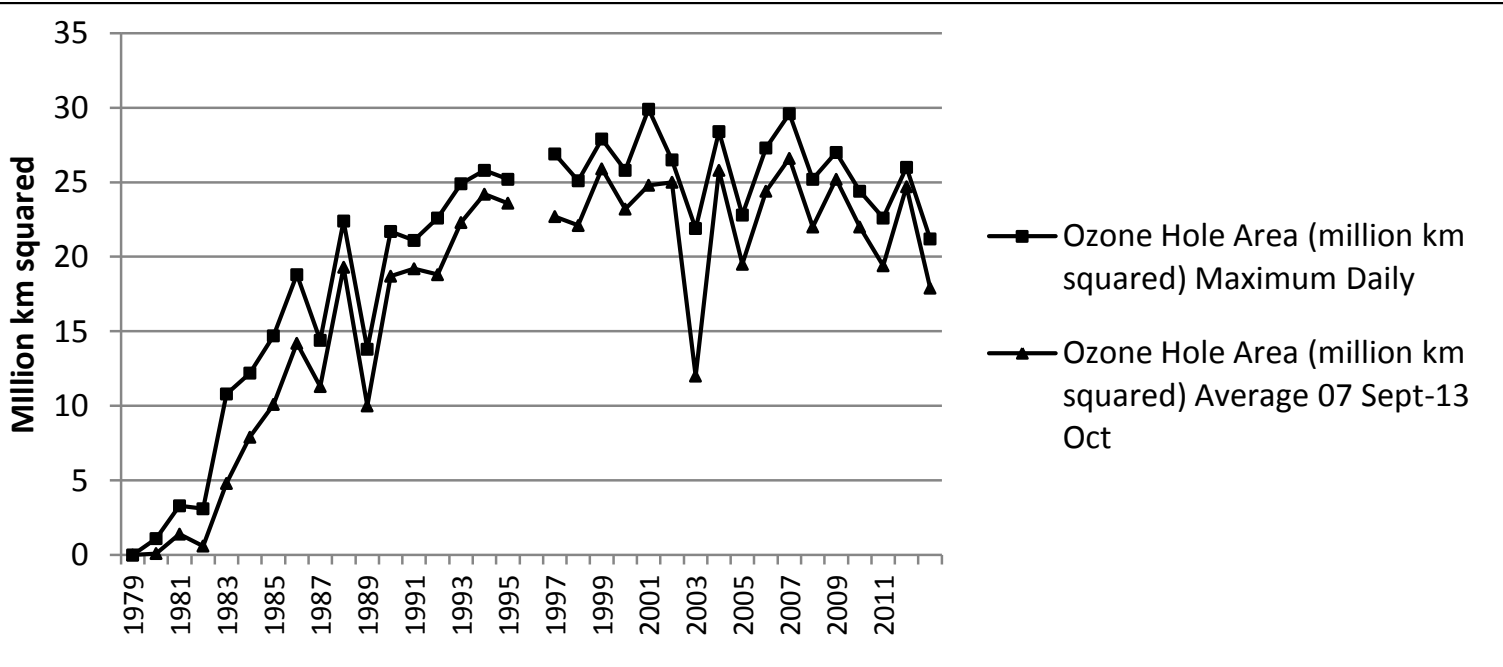

Source: http://ozonewatch.gsfc.nasa.gov/meteorology/annual_data.html; http://ozonewatch.gsfc.nasa.gov/facts/hole.html.

Category (3) Examples: Highly-Migratory Ocean Fisheries as Illustrated by the Atlantic Bluefin Tuna, and Greenhouse Gas Emission Controls.

Category (3) cases have the highest transaction costs of assigning property rights to mitigation rents. Scientific uncertainty regarding the extent, spread, and timing of externality losses, responses to controls, and mitigation costs are far greater than for the other two 
categories. Differences in preferences and perceptions of the value of externality control across global populations are more critical. Given the broader scope of these externalities, there is more asymmetric information about contributions to the problem, compliance, and regional or localized resource reaction to controls. Enforcement costs are much higher. Moreover, new entry is relatively easy. In the case of highly-migratory wild-ocean fisheries, this phenomenon is termed the "new country" problem as fishers from other countries are attracted to the rents created by harvest restrictions (Munro 2000; Balton 2001). In the case of GHG emission restrictions, it is termed "leakage" as producers in participating countries either migrate to other countries to avoid regulatory compliance costs, or shift away from fossil fuels, which lowers their prices and encourages their use in unregulated jurisdictions. (Bushnell and Mansur 2011). Mitigation rents are not easily boundable or capturable, particularly by the parties that bear the greatest costs. For these reasons, property rights in Category (3) cases are incomplete or absent. Wild Ocean Highly-Migratory Fisheries.

Many highly-migratory fish populations roam far across the vast oceans of the planet. They cross the high seas, well beyond the 200-mile exclusive economic zones (EEZs) of coastal states recognized by the United Nations Convention on the Law of the Sea (UNCLOS). ${ }^{39}$ Highlymigratory stocks are subject to competitive fishing by vessels from multiple countries, and many stocks have declined significantly. UNCLOS, the 1995 Food and Agriculture Organization (FAO) Code of Conduct for Responsible Fisheries, and the 1995 UN Agreement on the Conservation and Management of Straddling Fish and Highly-Migratory Fish Stocks (UNFSA)

\footnotetext{
${ }^{39}$ The UN Convention on the Law of the Sea followed the third UN Conference on the Law of the Sea (UNCLOS III) adopted in 1982. UNCLOS Annex 1 lists Highly-Migratory Species (UN 1982). See Stokke (2001) for discussion.
} 
call for international cooperation to control harvests. ${ }^{40}$ Stock assessments that show deteriorating conditions indicate that little has been achieved (Upton and Vitalis 2003; Myers and Worm 2003; Devine et al 2006; Maguire et al. 2006; Beddington et al. 2007; Worm, et al. 2009; McWhinnie 2009; Food and Agricultural Organization 2010; 2012, 4, 54-55; and Pinsky et al 2011).

In contrast, there are some bilateral treaties among adjacent countries on management of trans-boundary fish stocks, and if stocks remain generally within cooperating countries' EEZs, the transaction costs of negotiating property rights agreements are low enough to ensure greater success. ${ }^{41}$ In these bilateral cases there generally is less scientific uncertainty regarding fish stocks, harvest externalities, or stock recovery; fewer differences in management objectives; fewer informational asymmetries; and compliance and entry can be policed within the EEZ. Transfers to achieve constituent support take place within each country through preferential property rights, limits on property rights trading to protect particular interests, such as local fishing communities, and compensation for vessel reduction (buybacks) and other payments. The North Pacific halibut fishery, shared by the U.S. and Canada, is a good example of a case where property rights have been established within each country's EEZ and stocks and values have rebounded (Casey et al 1995; Grafton et al 2000; Fox et al 2003; Herrmann and Criddle 2006; and McDorman 2009).

\footnotetext{
${ }^{40}$ A summary of UNCLOS is available here: http://www.un.org/Depts/los/convention_agreements/convention_historical_perspective.htm. The 200-mile EEZ was establishe by the third United Nations Conference on the Law of the Sea (UNCLOS III) held between 1973 and 1982.UNCLOS came into force on November 16, 1994. The 1995 Code of Conduct for Responsible Fisheries is described at FAO (1995) and ftp://ftp.fao.org/docrep/fao/005/v9878e/v9878e00.pdf, and the 1995 Agreement for the Implementation of the Provisions of the United Nations Convention on the Law of the Sea of 10 December 1982 Relating to the Conservation and Management of Straddling Fish Stocks and Highly Migratory Fish Stocks can be found at http://www.un.org/Depts/los/convention_agreements/texts/fish_stocks_agreement/CONF164_37.htm.

${ }^{41}$ Ocean Law ICS provides a list of multilateral and bilateral agreements. The project website is http://www.oceanlaw.net/projects/current/ifa.html. The most recent FAO report on their Fisheries Agreements Register (FARISIS) is from 1999. See http://www.fao.org/docrep/meeting/W9885E.htm. 91 of the agreements in FARISIS are bilateral.
} 
The transactions costs of assigning property rights over highly-migratory ocean fisheries are far greater than over regional ones. The main demanders for property rights are fishers from developed countries with existing capital and expertise in the fishery. They stand to capture the greatest rents from stock rebounds. ${ }^{42}$ The supply of property rights requires agreement among delegates from established-fishing countries and with those from newly-entering countries that are attracted by fishery rents. Fishers from new-entrant countries cannot be excluded because international maritime law requires exploitation of the seas beyond country exclusive economic zones be open to nationals of all nations. ${ }^{43}$

Although scientific uncertainty regarding fish stocks, their location, and response to conservation plays a role in limiting agreement on property rights, the key impediments are differential preferences, asymmetric information, and enforcement incentives among fishers from developed and developing countries and their political representatives. Regional Fishing Management Organizations (RFMOs), established by the Law of the Sea to manage highmigratory species, set an annual total allowable catch (TAC) consistent with maximum sustainable yield or other criteria and allocate the quotas across RFMO members. Member countries, in turn, distribute the quota among their fishing fleets. As new fleets enter the fishery, however, existing property rights holders cannot capture mitigation rents (Bjørndal et al 2000). Accordingly, developed countries seek to grandfather existing fleets and historical harvest levels while developing countries join the RFMO and seek quota reallocation and expansion of their

\footnotetext{
${ }^{42}$ Johnson and Libecap (1982) demonstrate that higher-skilled fishers will support property rights if their differential talents and the inframarginal rents earned under open access are respected in any formal rights assignment.

${ }^{31}$ Convention on the Law of the Sea Article, 116, Dec. 10, 1982, 1833 U.N.T.S. 397 and Articles 8, 10, and 11 of the 1995 UN Agreement on the Conservation and Management of Straddling Fish and Highly-Migratory Fish Stocks.
} 
fishing rights (Pintassilgo and Duarte 2000; Rayfuse 2006, 4-6; Crothers and Nelson 2007, 342;

Grafton et al 2010; Van Dyke 2010, 165 and Korman 2011, 742).

Perhaps no fishery better reflects the high transaction costs of assigning property rights than the Atlantic bluefin tuna (Fromentin and Powers 2005; Fromentin 2010; Allen et al eds 2010). Bluefin tuna are the world's most valuable fish by weight (Korman 2010, 701). Prices are often greater than $\$ 100,000$ per fish; in January 2013, a 489-pound tuna sold for $\$ 1.78$ million at Tokyo's Tsukiji fish market. ${ }^{44}$ Worldwide, five RFMOs manage tunas and other highlymigratory species in their jurisdictions: the Inter American Tropical Tuna Commission, the Western and Central Pacific Fisheries Commission, the Indian Ocean Tuna Commission, the Commission for the Conservation of Southern bluefin Tuna, and the International Commission for the Conservation of Atlantic Tunas for the Atlantic (ICCAT) (Cullis-Suzuki and Pauly 2010). ${ }^{45}$

The ICCAT, which covers the Atlantic, the Mediterranean Sea, and the Gulf of Mexico, was established in 1969 in response to declines in the two Atlantic bluefin stocks. It is the oldest RFMO, preceding UNCLOS. ${ }^{46}$ Figure 4 illustrates ICCAT's management area, the two stocks within its jurisdiction (divided by ICCAT along the $45^{\circ} \mathrm{W}$ meridian), and their perceived migratory patterns and spawning grounds. Despite this early organizational effort, the Atlantic bluefin tuna is currently the most vulnerable bluefin tuna species (National Research Council 1994; Ellis 2008; Lischewski 2010, xiii). Stocks in the eastern and western Atlantic have steadily declined from historic levels, and current harvests appear unsustainable (Miyake et al

\footnotetext{
${ }^{44}$ http://en.mercopress.com/2013/01/12/bluefin-tuna-opens-2013-with-record-auction-price-at-tsukiji-1.78-milliondollars. It should be noted, however, that very high January prices are partly driven by ceremonial factors and are higher than average.

${ }^{45}$ A broad map of these RFMOs can be found at: http://ec.europa.eu/fisheries/cfp/international/rfmo/index_en.htm. ${ }^{46}$ International Convention for the Conservation of Atlantic Tunas opened for signature May 14, 1966, 673 U.N.T.S. 63, 20 U.S.T. 2887.
} 
Figure 4: ICCAT Management Area and Bluefin Tuna Migration Patterns
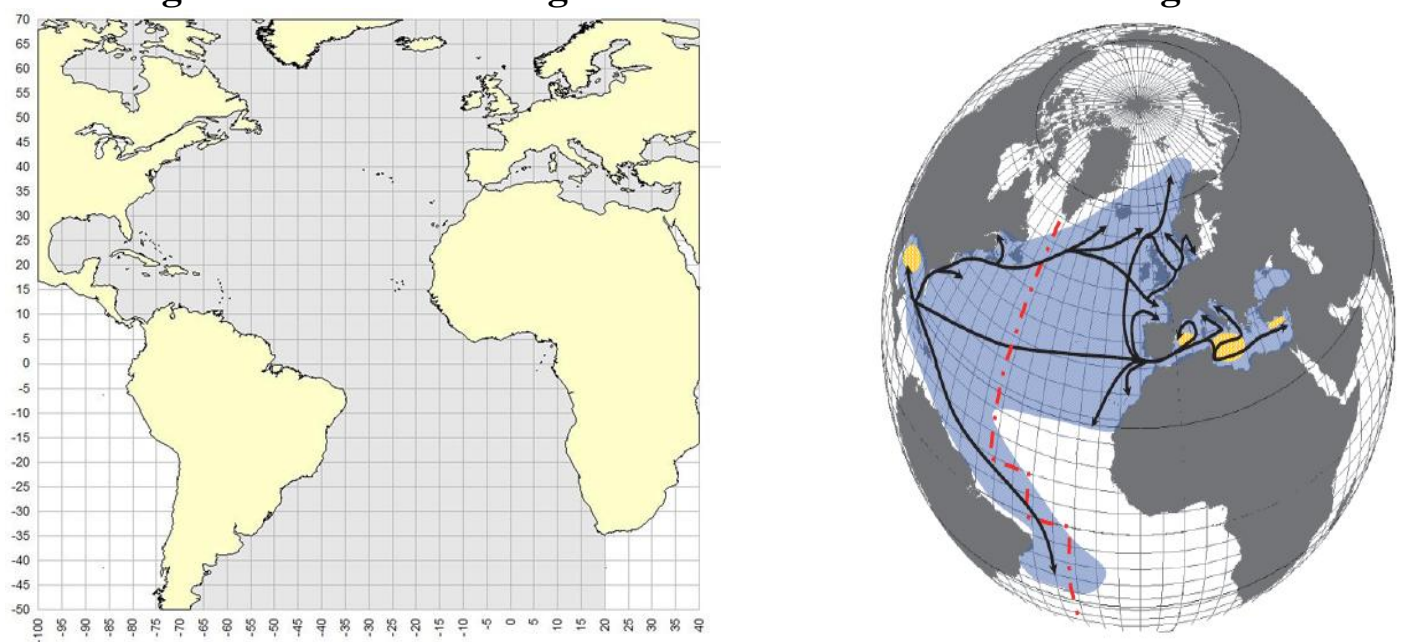

Source: ICCAT Convention Area http://www.iccat.int/en/convarea.htm. Map of the spatial distribution of Atlantic Bluefin tuna, main migration routes and spawning grounds. The vertical dashed line depicts the stock delimitation between the two current ICCAT management units (modified after Fromentin and Powers 2005).

Figure 5 presents the spawning stock biomass and total allowable catch for the eastern and western Atlantic bluefin stocks. ${ }^{47}$ As shown, the biomass for both has fallen. The eastern stock peaked around 315,000 metric tons in 1958 and the western at 52,000 metric tons in 1973. TACs were first assigned to the eastern stock in 1998 and in the early 1980s for the western stock (International Commission for the Conservation of Atlantic Tunas (ICCAT) 2011, 634; $2012,80)$. Even so, there has not been sufficient agreement among the members to reduce the TACs sufficiently to rebuild the stocks.

\footnotetext{
${ }^{47} \mathrm{SSB}$ is the biomass of mature adult fish measured in metric tons. According to the 2010 stock assessment, bluefin in the eastern fishery reach maturity around age 4 and those in the western fishery around age 9 (International Commission for the Conservation of Atlantic Tunas (ICCAT) 2011, 3) http://www.iccat.int/Documents/CVSP/CV066_2011/no_2/CV066020505.pdf.
} 
Figure 5: Atlantic Bluefin Spawning Stock Biomass and TACs by Region
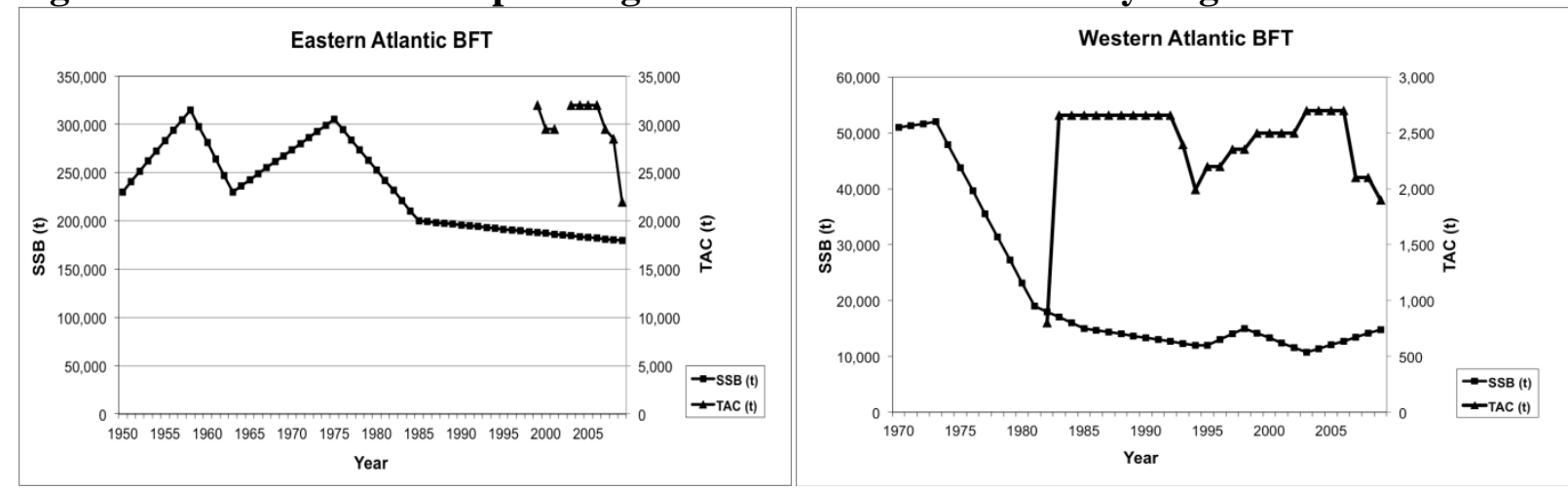

Source: Spawning stock biomass (SSB) and TACs are both reported in metric tons. TAC information comes from (International Commission for the Conservation of Atlantic Tunas (ICCAT) 2011, 633-634);

http://tagagiant.org/policy/atlantic/atlantic-international; and )

http://www.iccat.es/Documents/BienRep/REP_EN_10-11_II_2.pdf. SSB data is imputed from (International Commission for the Conservation of Atlantic Tunas (ICCAT) 2011, 648, 672). Eastern SSB was imputed from the Run 13 data reported in Figure 22. Stock levels were determined for unreported years linearly interpolating from information contained in the document text as follows: 230,000 (1950), 315,000 (1958), 230,000 (1963), 305,000 (1975), 200,000 (1985), 179,550 (2009). Western SSB was imputed from the data reported in Figure 53. Stock levels were determined in the same manner from information contained in the document text as follows: 51,000 (1970), 52,000 (1973), 19,000 (1981), 15,000 (1985), 12,000 (1994), 15,000 (1998), 10,710 (2003), 14,790 (2009).

There is scientific uncertainty about stock status. Although the species has been well studied, its mobility makes stock assessments and determination of the impact of regional fishing on broader stocks imprecise (International Commission for the Conservation of Atlantic Tunas (ICCAT) 2008; Joseph et al 2010, 12-13; Korman 2010). ${ }^{48}$ ICCAT country delegates interpret stock uncertainty differently, widening the scope for disagreement on property rights. More importantly, there are differences in preferences for stricter controls among ICCAT members (Barkin 2004).

Between 1983 and 1991, ICCAT quota allocations were heavily weighted by historical harvest. At the insistence of new members, more weight has been given to coastal state proximity to the fishery and developing country fishing industries (Grafton et al 2010, 156-7; Joseph et al 2010,19). This TAC distribution encourages entry and reduces support for major TAC reductions among all RFMO members. As shown in Table 3, by 2010, developing

\footnotetext{
${ }^{48}$ The ICCAT Standing Committee on Research and Statistics (SCRS) provides stock assessments for TACs consistent with MSY and for coordinating the research activities of the various member nations.
} 
countries had increased their share of the bluefin tuna fishery. ${ }^{49}$ The number of ICCAT members grew from 9 in 1970 to 48 in 2008, and most new members are developing countries. ${ }^{50}$

Table 3: Entry into the Eastern Atlantic Bluefin Tuna Fishery

\begin{tabular}{ccccc}
\hline $\begin{array}{c}\text { Country } \\
\text { Group }\end{array}$ & $\begin{array}{c}\text { Year } \\
\text { Joined } \\
\text { ICCAT }\end{array}$ & $\begin{array}{c}\text { Number of } \\
\text { Active } \\
\text { Vessels }\end{array}$ & $\begin{array}{c}\text { 1980 Harvest } \\
\text { Share (\%) }\end{array}$ & $\begin{array}{c}\text { 2008 Harvest } \\
\text { Share (\%) }\end{array}$ \\
\hline \hline & & 356 & 85.5 & 59.2 \\
Developed $^{1}$ & $1970-2004$ & 656 & 14.5 & 41.8 \\
\hline Developing $^{2}$ & $1969-2007$ & 6 & & \\
\hline
\end{tabular}

${ }^{1}$ Developed countries include: European Union (France, Spain, Italy, Greece, Malta, Cyprus, Portugal, Ireland, and Denmark), Norway, Japan, Iceland, and Korea.

${ }^{2}$ Developing countries include: Morocco, Croatia, Tunisia, Libya, Turkey, Algeria, China, Egypt, Syria, Yugoslavia, Panama, and Chinese Taipei.

Source: Year joined : http://www.iccat.int/en/contracting.htm; Vessels: http://www.iccat.int/en/vesselsrecord.asp; Harvest data: International Commission for the Conservation of Atlantic Tunas (ICCAT) (2011, 614-17).

Member country coalitions form to block changes in management policies (Pintassilgo and Duarte 2000, 361-3; Duarte et al 2000; Lindroos 2002; Bjørndal and Brasão 2006; Alcock 2010, 251-68). In 2010, a proposal to list the Atlantic bluefin tuna under CITES, which would prohibit its international trade, failed by a vote of 20 to 68 with 30 abstentions, largely along developing/developed country lines (Crook 2010, Convention on International Trade in Endangered Species of Wild Fauna and Flora (CITES) 2010, 2). Representatives from developing countries opposed CITES listing because of tighter constraints on bluefin trade.

Asymmetric information about harvests and their effects on the stock also raise transaction costs. Individual fishing vessels have information on their catch that may not be accurately presented to country regulators because it fills their quota. Further, the harvest of juveniles below the allowed size is unlikely to be reported to the ICCAT. Illegal harvests can

\footnotetext{
${ }^{49}$ ICCAT maintains an online database of vessels authorized to fish actively for Bluefin tuna in the eastern Atlantic and Mediterranean Sea. See http://www.iccat.int/en/vesselsrecord.asp.

${ }^{50}$ A list of ICCAT Contracting Parties is available online at http://www.iccat.int/en/contracting.htm
} 
only be roughly estimated. ${ }^{51}$ Finally, enforcement of ICCAT rules is costly given the broad expanse of jurisdiction (as shown in Figure 4) as well as the ease of entry. Trade sanctions also appear to have been relatively ineffective instruments (Barrett 2005, 326-7; Hallman, et al 2010, 197-8; Webster 2010, 325-7).

Bluefin and other tunas fare better in another RFMO, the Western and Central Fisheries Commission (WCPFC), where property rights can be made more definite. ${ }^{52}$ Established in 2004, WCPFC involves the cooperation of fourteen Pacific Island countries and eight territories whose exclusive economic zones overlap most of the relevant sea. Entry is limited because this setting more closely satisfies Scott's (1955) sole ownership condition. There is less scientific uncertainty about stock conditions because of the narrower spatial range of the RFMO. The membership also has similar preferences, and there are fewer information asymmetries. The countries in the WCPFC are comparatively homogeneous in terms of their economic development; they do not have significant domestic fleets but instead have processing industries; and eight of the countries coordinate management through the Parties to the Nauru Agreement of 1982. These factors lower the transaction costs of agreement on property rights. Under the Nauru Agreement an annual total allowable effort is set and distributed as tradable vessel days among licensed vessels (Gillet 2010; McClurg 2012). Local cooperation to address this broad externality is successful because it meets Ostrom's design criteria (McClurg 2012).

\section{GHG Emission Controls.}

Collective reduction of GHG emissions from sources within sovereign nations is by far the most difficult international collective action problem. For this reason, this case is described

\footnotetext{
${ }^{51}$ ICCAT maintains a list of IUU vessels available online at http://www.iccat.es/en/IUU.asp. Many IUU vessels are of unknown nationality. Among vessels with a known flag, Indonesia is listed seven times and Bolivia, Columbia, Georgia, Guinea are each listed once.

52 www.wcpfc.int/.
} 
in more detail than the others in the review. Settling on international property rights for mitigation involves all four of the sources of high transaction costs outlined in Section I: extreme scientific uncertainty, pronounced differences in preferences and perceptions of the costs and benefits of mitigation across global populations, asymmetric information regarding costs and benefits and contributions to the problem, and new entry and enforcement difficulties.

Of all of the examples, the potentially negative effects of the GHG externality are the most truly global. Releases spread throughout the atmosphere so that abatement efforts within one country benefit populations in other countries. Emission reductions by particular producers and consumers are therefore a global public good. The benefits of reducing the extent of climate change cannot be exclusively captured by cooperating countries or interests within them. As the IEA literature predicts, free riding is possible even when non-cooperation can be observed. An analysis of transaction costs reveals the underlying impediments to contractual arrangements among international leaders.

Multilateral efforts to limit emissions, whether they take the form of cap-and-trade in emission allowances, carbon taxes, or other regulations, define property rights to the rents from mitigation. Neither the costs nor the benefits, however, are distributed uniformly. This creates a major bargaining problem. Residents of regulated countries must incur costs but the benefits of their abatement efforts are spread over the planet in unknown ways. Because of the high level of scientific uncertainty regarding the distribution of damages avoided through mitigation, it is not surprising that international agreement on property rights to address the externality has not occurred. A brief review of the GHG policy literature is provided and then each of the sources of high transaction costs is examined in more depth. 
Anthropogenic GHG sources come from virtually all human consumption and production activities. Archer $(2007,2009)$ summarizes anthropogenic contribution to warming with historical data and projections of emissions and temperature increases. Abatement to stabilize atmospheric GHG concentrations at levels sufficient to avoid future serious global climatic reaction requires significant declines in fossil fuel use across major economies involving at least the 3-4 dozen of the largest emitters (Aldy et al 2010, 925-8), raising current energy costs and likely forcing economy-wide adjustments in income and consumption (Greenstone and Looney 2012). There is a large literature on the GHG externality including Barrett (2005, 359-406) who compares climate-change negotiations with the far-easier-to-negotiate Montreal Protocol. Abatement policies are described in Goulder and Parry (2008); Metcalf (2009); Aldy et al (2010); Victor (2011, 30-58, 241-62); Aldy and Stavins eds (2010); and Fullerton and Wolfram eds (2012); and Metcalf et al (2012).

The primary demanders of international controls on GHG releases are citizens' groups within developed or industrialized nations, their political representatives, and related environmental NGOs. These nations are termed "Annex I" countries as parties to the United Nations Convention on Climate Change (UNFCCC). ${ }^{53}$ Under the Kyoto Protocol of 1997 , delegates from these countries agreed to reduce GHG emissions by an average of $5 \%$ relative to their 1990 levels by $2012 .^{54}$ The U.S. was alone among industrialized nations in not ratifying the Protocol. In contrast with most developed countries, however, citizens of less-developed countries and their political leaders have been less willing to assume the costs of mitigation, even though they are expected to be the primary beneficiaries. ${ }^{55}$ In a manner similar to the Montreal

\footnotetext{
${ }^{53}$ A list of Annex I countries is found at http://unfccc.int/parties_and_observers/parties/annex_i/items/2774.php.

${ }_{55}^{54}$ http://unfccc.int/kyoto_protocol/items/2830.php.

55 See discussions in http://www.epa.gov/climatechange/impacts-adaptation/international.html; http://unfccc.int/essential_background/background_publications_htmlpdf/climate_change_information_kit/items/28
} 
Protocol, these countries were exempted from emission controls in the Kyoto Protocol that expired in 2012 under the notion of "common, but differentiated responsibilities." Equity arguments for this distribution are outlined in Lasse et al (2002) and Agarwala (2010, 182-5).

The supply of mitigation property rights is determined by the internal and international control policies agreed upon by politicians of major-emitting countries. China, the U.S., India, Russia, Japan, Canada, plus the E.U. account for roughly $75 \%$ of GHG releases ${ }^{56}$ While, as a minimum, it is necessary for these countries to participate in any future international environmental agreement, the cooperation of other rapidly-growing countries, such as South Korea, Brazil, South Africa, Indonesia, and Mexico is also needed to constrain emissions. Several papers explore how regional and national cap-and-trade, taxation, or regulatory policies that are more usual in the E.U. and U.S. might be integrated into a global network among countries that have dissimilar macroeconomic, political, and governance conditions (Becker et al 2010; Cooper 2010, 154-71; Jaffe and Stavins 2010, 122, 129, 133-40; Frankel 2010a; Keohane and Raustiala 2010, 374; McKibbin et al 2010).

Among the policies considered, a cap-and-trade system of emission allowances has emerged as the most common GHG-control mechanism. It was the primary component of the Kyoto Protocol. In 2003 the European Union implemented a community-wide Emissions Trading Scheme (the EU ETS) to meet its Kyoto targets, creating the most ambitious international emission allowance market. Gradually-tightening caps on total GHG discharges were set across E.U. member nations and allowances were distributed to units in the largest emitting sectors. Trading began in 2005 with an inaugural Phase I that ran through 2007; Phase

8.php; and the April 2007 article by Gregg Easterbrook in the Atlantic Magazine, http://www.theatlantic.com/magazine/archive/2007/04/global-warming-who-loses-and-who-wins/305698/. ${ }^{56}$ http://www.epa.gov/climatechange/ghgemissions/global.html. 
II ran from 2008 to 2012; and Phase III runs from 2013 to 2020 (Ellerman and Buchner 2007;

Ellerman 2010; Creti et al 2013).

Stavins (2008, 305-58) and Keohane (2009) provide comprehensive discussions of the design of a similar U.S. cap-and-trade program. The U.S. considered one in 2009-2010 with the Waxman-Markey bill that did not pass Congress. ${ }^{57}$ Instead, regional cap-and-trade policies have been adopted, including the Regional Greenhouse Gas Initiative (RGGI) of nine New England and Mid-Atlantic states where cross-state trading began in 2009 with the objective of lowering GHG releases to 10\% below 1990 levels by 2020; and the nascent California AB 32 (California Global Warming Solutions Act of 2006) designed to lower GHG discharges among regulated entities to 1990 levels by 2020. Trading began under AB 32 in November 2011.

Nevertheless, the future of cap-and-trade for emissions regulation is uncertain. The highest RGGI allowance auction price was $\$ 3.51$ in March 2009, and since that time, prices have trended down, clearing at the end of 2012 at $\$ 1.93 /$ allowance for one ton of released $\mathrm{CO}_{2} \cdot{ }^{58}$ This price is far lower than any of the available estimates (which vary widely, depending on the underlying assumptions) of the social cost of carbon (SCC). The U.S. Interagency Working Group on Social Cost of Carbon (2010) estimates an average SCC of $\$ 21 .{ }^{59}$ It is too soon to assess the effectiveness of California cap-and-trade system. Bailey et al (2013) argue that statemandated renewable energy portfolio standards, low carbon fuel standards, and new fuel economy and energy standards could undermine permit demand and permit prices, thereby reducing incentives for private investment in abatement technologies. Indeed, as shown in Figure 6, EU ETS permit prices have trended downward from a peak of around $30 €$ in 2006 and 2008 to

\footnotetext{
${ }^{57}$ American Clean Energy and Security Act of 2009, HR 2454.

${ }^{58} \mathrm{http}: / /$ www.rggi.org/market/co2 auctions/results; RGGI Annual Report for 2012, http://rggi.org/.

${ }^{59}$ For discussion of the SCC see Pindyck (2013). The SCC has recently been updated to $\$ 33$. http://www.whitehouse.gov/sites/default/files/omb/inforeg/social_cost_of_carbon_for_ria 2013 update.pdf Table 2.
} 
a spot price of $3.89 €$ in June 2013, again undercutting any effect allowance prices might have on investment and energy consumption to meet E.U. emission targets. ${ }^{60}$ Delegates from E.U. member countries with different economic growth rates and energy and abatement costs have not agreed upon allowance supply reductions to raise prices (Ellerman 2010, 115). ${ }^{61}$

Figure 6: EU ETS Allowance Prices

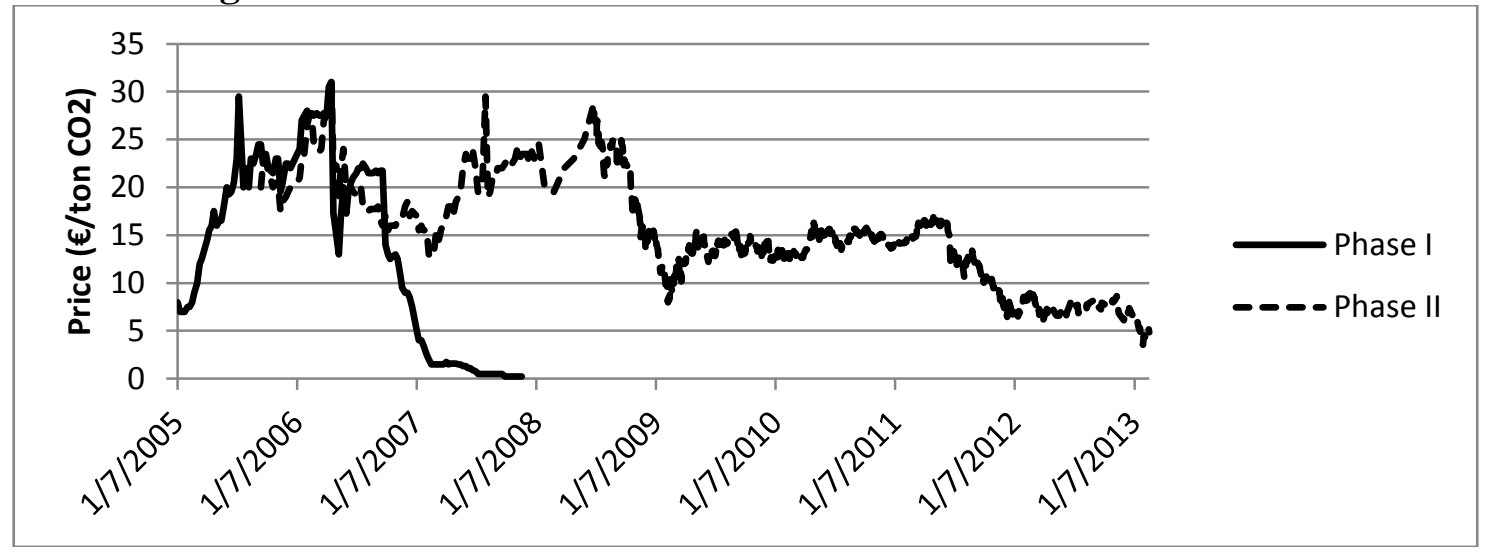

Source:_Price data from: http://www.c2es.org/docUploads/EU-ETS-In-Perspective- Report.pdf; http://www.c2es.org/docUploads/EU-ETS-In-Perspective- Report.pdf ; http://downloads.theccc.org.uk/docs/21667\%20CCC\%20Report\%20Chapter\%202.pdf; http://www.ecotrade.pt/?m=201201\&cat=10\&lang=en; http://www.bloomberg.com/quote/EECXSYR1:INDhttp://www.chaireeconomieduclimat.org/?page_id=225 9\&lang=en.

What is going on with cap-and-trade? How is this related to transaction costs and what do they portend for regional and global GHG emission-allowance trading schemes? There now is enough information on various allowance trading practices, ranging from the lead phase-out program in the U.S. from 1982-87 (Newell and Rogers 2003) to the $\mathrm{SO}_{2}$ market, to the Regional Clean Air Incentives Market (RECLAIM) of Southern California (Johnson and Pekelney 1996), to RGGI (Metcalf 2009), and to the EU ETS for an analysis of policy designs and the implicit

\footnotetext{
${ }^{60}$ ICE Futures Europe, June 2013 https://www.theice.com/homepage.jhtml

${ }^{61}$ For example see discussion in the Economist Magazine April 20, 2013, "ETS, RIP?" at http://www.economist.com/news/finance-and-economics/21576388-failure-reform-europes-carbon-market-willreverberate-round-world-ets.
} 
property rights to mitigation rents defined by them. Goulder (2013) and Newell et al (2013)

provide background for such research.

The checkered experience with cap-and-trade and the lack of robust political support for it seems reflective of the broader transaction costs of international cooperation on climate change. The efforts to confront the problem under the Kyoto Protocol have been unsuccessful in meeting Kyoto's objectives (Helm 2008). Figure 7 plots GHG releases from 1992 to 2010 for developed and developing countries. The figure also shows the Kyoto emissions target for developed economies and the cumulative number of transnational delegate meetings of the Conference of Parties (COP) to the United Nations Framework Convention on Climate Change, as well as the associated meetings of the Subsidiary Body for Implementation of the Protocol (SBI) and the Subsidiary Body for Scientific and Technological Advice (SBSTA). ${ }^{62}$ Despite continued COP meetings to elicit cooperation, the Protocol did not achieve its goals and lapsed in 2012. Although emissions from developed countries have been flat, in part due to deteriorating macroeconomic conditions, those from developing countries have grown, especially from China and India. ${ }^{63}$ With these facts in mind, it is important to examine in detail the specific transaction costs that have bedeviled efforts to control GHG releases.

\footnotetext{
${ }^{62}$ Four organizations meet as part of the COP-- the SBI, SBSTA, AWG-KP (Ad Hoc Working Group on Further Commitments for Annex I Parties under the Kyoto Protocol), AWG-LCA (Ad Hoc Working Group on Long-term Cooperative Action under the Convention), and in 2012, the ADP (Ad Hoc Working Group on the Durban Platform for Enhanced Action). The literature includes Clemencon (2008); Barrett (2010); and Aldy and Stavins (2012). ${ }^{63}$ China's emissions went from 2,449.162 million metric tons in 1992 to 8,320.963 million metric tons in 2010, surpassing the United States at 5,610.108 million metric tons. India's rose from 659.3701 in 1992 to 1,695.623 million metric tons in 2010 http://www.eia.gov/cfapps/ipdbproject/IEDIndex3.cfm?tid=90\&pid=44\&aid=8 Cooper $(2010,152)$ argues that even if developed countries reduced emissions to zero over the next decade world GHG totals would still be at 1990 levels or higher due to increases from developing countries.
} 


\section{Figure 7: GHG Releases by Origin Across Developed and Developing Countries and Cumulative COP, SBI and SBSTA Meetings.}

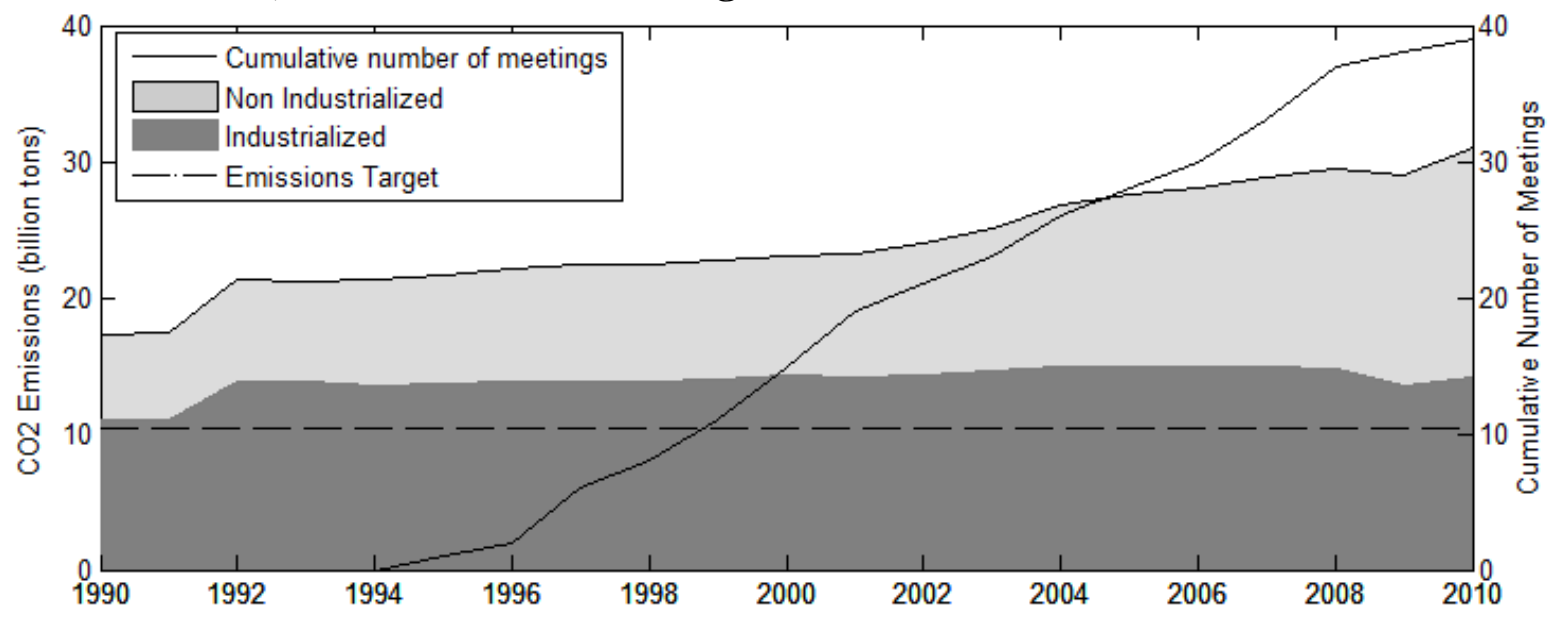

Source: $\mathrm{CO}_{2}$ emissions are in billions of tons. The data are compiled from the United States Energy Information Administration, International Energy Statistics. The emissions target represents the 5.2\% decrease in emissions below the 1990 level, as agreed upon in the Kyoto Protocol. The cumulative number of meetings includes those of the COP, SBI and SBSTA. They are taken from the UNFCCC. The figure was adapted from Aldy and Stavins (2012).

Scientific Uncertainty.

Scientific uncertainty plagues all aspects of multinational climate change negotiations. It is recognized in the literature, but its implications for the transaction costs of property rights assignment are not developed. Pindyck (2013), Stern (2013) and Weitzman (2013) provide valuable discussions of scientific uncertainty and the difficulty it poses for consensus assessments of the costs of GHG accumulations. According, only key points of damage uncertainty are reviewed here.

In large complex natural systems that characterize Category (3) externalities, damages accumulate in unknown or uncertain ways across time and space. Not all parties assess damage uncertainty in the same manner. This makes it difficult for affected parties to determine their welfare under different control strategies and to value the costs and benefits associated with different assignments of mitigation property rights. Hallegatte et al (2012, 3-5) refer to the problem of deep uncertainty whereby analysts do not know or cannot agree on (i) models that 
relate key climatic forces over time, (ii) parameter probability distributions, and/or (iii) the value of alternative outcomes. Analysts rely upon historical weather and climate data and climate models, but climate models cannot provide the equivalent of historical data for future projections.

Hallegatte et al (2012, 6-10) claim that climate-change damage uncertainties arise for four reasons. First, future GHG emissions are linked to demographic and socio-economic conditions that will vary across the planet and across time in complex ways that are incompletely understood. Second, understanding of global and regional climate systems, their interactions, and feedbacks with rising GHG levels is highly imperfect. Third, knowledge of natural climatic variability is very limited. Fourth, the reactions of ecological systems to climate change are unpredictable, site-specific and non-linear.

General Circulation Models (GCMs) that are used to simulate the relationships between GHG emissions growth and climate tend to predict similar broad patterns--more warming at high latitudes than low, more precipitation at higher latitudes than in the tropics, and more precipitation around the equator. Regional Climate Models (RCMs), however, perform poorly with considerable measurement error (Kerr 2001; Deshpande and Greenstone 2010, 9; Aldy et al, 2010, 914-16). ${ }^{64}$ Natural variability due to shifting cloud cover and other factors is more important at the regional than global scale, contributing to uncertainty about the effects of climate change at a local level. Moreover reliable historical weather and climate data series for the most vulnerable regions do not exist for linking global and local phenomena. Finally, historical emission patterns are unlikely to persist in regions that are undergoing rapid economic development and demographic shifts. Accordingly, it is much more difficult to predict future

\footnotetext{
${ }^{64}$ See the special report on the Regional Impacts of Climate Change: Simulations using Statistical Downscaling and Regional Climate Modeling Systems (http://www.ipcc.ch/ipccreports/sres/regional/312.htm).
} 
regional climates and the benefits of GHG abatement for specific populations and countries across the planet than to predict global patterns.

For all regions, calculating probabilities of future climate changes based on projections from climate models requires subjective, expert judgments. These vary with the assumptions used and are likely to be extremely controversial, particularly if they are the basis for differential constraints placed across populations on GHG releases, production patterns, and consumption possibilities, as well as the determination of amounts and direction of international transfer payments. What matters for local populations deciding whether to support GHG controls is the anticipated impact on regional water supplies, crop yields, sea levels, temperatures, health, and other related outcomes. Regional climate uncertainty makes it very difficult for local and national leaders to forge a political consensus for taking action.

This situation reduces the willingness-to-pay to reduce GHG emissions and limits the concessions country delegates are willing to offer to achieve international agreement. Using the most recent information on the likely range of global GCM parameters, Pindyck $(2012,290)$ estimates the fraction of consumption that a society would be willing to sacrifice in perpetuity to limit temperature increases to $2-3^{\circ} \mathrm{C}$ and reports willingness-to-pay estimates below $2 \%$ of GDP. Similarly, Barrett $(2005,376-9)$ presents estimated climate change damages and abatement costs that indicate very low benefit-cost ratios for aggressive mitigation in the U.S. Viscusi and Zeckhauser $(2006,152,161-3)$ also report low willingness-to-pay in their survey of Harvard graduate and law students in 2004. New hazardous weather patterns, such as increases in hurricane risk from global warming, however, induce a higher reported willingness-to-pay in their survey. This suggests that uncertainty in mitigation benefits may be reduced in places where climate change results in more extreme weather. 
There also is uncertainty regarding the costs of mitigation (Barrett 2005, 377). Stern (2007) suggests that the annual costs of stabilizing $\mathrm{CO}_{2} \mathrm{e}\left(\mathrm{CO}_{2}\right.$ equivalent) levels between 500 and $550 \mathrm{ppm}$ (slightly less than double the 1900 stock estimates of $300 \mathrm{ppm}$ ) are around 1\% of global GDP. There is, however, considerable disagreement about these cost estimates, and they may be higher or lower. Nordhaus (2007), Weitzman (2007), and Mendelsohn (2008), among others, criticize Stern's assumptions. Goulder and Perry $(2008,162)$ and Keohane $(2009,54)$ also briefly discuss uncertainty in the performance of competing mitigation policies, especially with regard to adoption of cap-and-trade programs relative to carbon taxes.

Meng (2013) combines an event study and prediction markets to gauge the impact of the Waxman-Markey cap-and-trade bill on the market value of listed firms and the lobbying expenditures made by managers of unlisted firms against the bill. He uses these data to estimate the cost to regulated firms and finds that Waxman-Markey would have reduced the market value of listed firms by $\$ 150$ billion with the greatest expected losses for carbon and energy-intensive firms. These figures do not include the effects on consumers from higher prices or on factor suppliers from lower real incomes.

Investment in new technologies that provide substitutes for fossil fuels in energy generation and consumption is a principal GHG abatement policy. There is considerable uncertainty regarding which alternative technology investments to support. Hallegatte et al $(2012,35)$ claim that with more known technologies, where uncertainty is shallow, expert analysis can derive relative probabilities, calculate risk, and rank investments. For less-wellunderstood technologies that may be more transformative over the long term, deep uncertainty makes such risk calculations and investment decisions much more difficult. Accordingly, incentives for this type of technology investment are reduced (Harstad 2012). If investment is 
delayed until more is known, catastrophic climate change may occur. Alternatively, if preemptive technology investments are revealed to be the wrong ones and irreversibly change the capital stock, society may be less able to address subsequent climate change (Kolstad 1996a, 1996b). Similar discussions of investment in abatement capital under uncertainty are found in Kolstad and Ulph (2008) and Victor (2011, 39-41).

Differential Preferences and Perceptions within Countries of Mitigation Benefits.

Joining a coalition of countries to alleviate the global GHG externality requires domestic support for the property rights implied by any international environmental agreement. As a result, within-country differences in preferences and perceptions are relevant for international cooperation. Public opinion surveys in developed countries suggest that backing for global climate action, such as the Kyoto Protocol, is positively associated with education and the business cycle (Kahn and Kotchen 2010, Tables 3-6, for the U.S.; Benegal and Scruggs 2012 for 29 European Countries). ${ }^{65}$ Within the U.S., political party (Democrat), gender (women), age (younger to middle age), upper income levels, and education (college and higher) are significant factors in explaining the demand for climate action. ${ }^{66}$

Public opinion surveys also reveal that populations value alleviation of local environmental externalities more highly than broader, more abstract, global ones. Local environmental problems are more easily understood (i.e. subject to less uncertainty), observable, and the benefits of confronting them are appropriable. Consider the near-universal public opposition to locating power plants in neighboring areas, even when these plants embody new

\footnotetext{
${ }^{65}$ The role of macroeconomic conditions in affecting support for climate policy also is demonstrated in Scruggs and Benegal (2012). The consumption preferences of individuals in the U.S. for provision of environmental public goods are examined by Kahn (2007) and Kotchen and Moore (2007, 2008).

${ }^{66}$ See Anthony Leiserowitz et al, Yale Project on Climate Change Communication. http://environment.yale.edu/climate-communication/article/Climate-Beliefs-March-2012/ and Stephen Ansolabehere, Harvard/MIT Energy Surveys, http://dvn.iq.harvard.edu/dvn/dv/energysurveys. See also McCright (2010) for an analysis of 8 years of Gallup data on climate change knowledge and concern.
} 
technologies that reduce GHG emissions (Ansolabehere and Konisky 2009, 571, 575;

Ansolabehere and Konisky 2012, 62; Fri and Ansolabehere 2012, 5-7). Ansolabehere and Konisky $(2012,68-9)$ also find that the choice of fuels for energy generation is determined more by concerns about local particulate emissions and toxic waste releases in regional air and water supplies than global $\mathrm{CO}_{2}$ discharges. Similarly, Nesbet and Myers' (2007, 445-62) analysis of 20 years of public opinion regarding global warming shows that while there is growing awareness of the problem, alarm remains focused on local pollution. Reiner et al (2006, 2095-7) surveyed citizens in the U.S., U.K., Sweden, and Japan and found that in the U.S. narrow environmental problems dominate global ones. Additionally, in both the U.S. and U.K. unease about the effects of global warming is confined to its impact within each country and there is no support for greater foreign aid to address the problem elsewhere. Finally, Tingley and Tomz (2012) report results of public opinion surveys in the U.S. and 25 other developed and lessdeveloped countries. Although there is general backing for addressing the problem in some manner, there is little enthusiasm for more specific policies, such as reciprocal cross-country reductions in fossil-fuel use. This evidence of mixed support reduces the payoff to politicians in major emitting countries from adopting costly policies to lower GHG emissions.

A related problem is the incidence of abatement costs that affects preferences for taking action. GHG emissions controls like emissions taxes, tradable emissions allowances (cap-andtrade), performance standards, and green technology/renewable energy mandates result in higher and more unstable energy prices, at least in the short run. They also induce changes in consumption patterns towards products and services that are less polluting and shift investment toward new energy technologies via subsidies and away from other investment options (Goulder and Parry 2008). In general, these policies are regressive; hence, as information about the costs 
of climate change policies becomes more widespread, lower-income groups and the politicians who represent them may oppose abatement unless transfers are provided. Wiener (2007, 106-13) discusses the legal and political barriers to assembling internal transfers of the magnitude that may be required.

The literature recognizes the distributional effects of carbon taxes or cap-and-trade in emission allowances. Goulder and Parry (2008) argue that the costs of these environmental policies depend upon whether they are designed for revenue recycling (i.e. to be revenueneutral). If revenue neutral, funds generated from taxes or emission-permit auctions could be used to reduce distortive income taxes, especially for low-income groups. In this way, climate change policies could be both efficiency-enhancing and progressive (Cooper 2010, 167-9; Metcalf 2009, 67-9; Metcalf et al 2012).

The amounts involved potentially are large. Rausch and Reilly $(2012,2)$ report Congressional Budget Office revenue estimates of $\$ 1.25$ trillion over 10 years from a carbon tax of \$20/ton applied in 2013 and rising in real terms at 4\% annually, an amount equivalent to 54\% of the total revenues ( $\$ 2.3$ trillion) collected by the federal government in fiscal year $2011 .^{67}$ There is scant attention in the literature, however, on the conditions under which politicians can commit to long-term revenue neutrality and avoid using the funds to finance narrow political agendas. Metcalf and Weisbach (2009) and Brunner et al (2012) suggest delegation of tax-rate setting to an independent agency to avoid political manipulation and policy reversal. Brett and Keen's (2000) model of environmental taxation predicts that instead of revenue recycling, funds will be targeted by green politicians toward earmarks in order to lock-in environmental programs. ${ }^{68}$ Earmarks, however, may not be of much use in tackling global environmental

\footnotetext{
${ }^{67} \mathrm{http}: / / \mathrm{www}$. cbo.gov/publication/43153.

${ }_{68}$ Anesi (2006) also models the use of earmarking as a means of constraining the range of future political budget
} 
problems and regressive policy effects. Instead, they often are viewed as political pork that rewards specific constituencies instead of providing broad public goods (Shepsle and Weingast 1981; Weingast, Shepsle, and Johnsen 1981; Weingast 1994; Bickers and Stein 2000).

There are related questions of how higher and more uncertain energy prices arising from carbon taxes, cap-and-trade, or mandates for renewable energy sources would affect consumer prices, real factor returns, and the supply of labor and other inputs (i.e. the so-called "taxinteraction" effects). Metcalf $(2009,69-74)$ reviews some of the possible general equilibrium effects of higher consumer prices resulting from abatement policies. Deschênes (2012) uses state-level panel data from 1976-2007 to estimate the relationship between real electricity prices and labor market activity in the U.S. He finds weak effects for the overall economy, but negative impacts for particular sectors, such as agriculture and transportation. Internal politics, however, are driven by such effects because they loom large in political jurisdictions where those sectors are dominant. The influence of the agricultural lobby in the U.S. in achieving particularistic beneficial legislation, for example, is well known. Hahn (2009) argues that political economy factors could easily undermine GHG policy objectives. The absence of much scholarly attention to the problem of long-term political commitment to global environmental policies may be attributed to the fact that the IEA literature models countries as uniform entities and downplays the extensive work on how interest-group politics influence public policies, including classics by Buchanan and Tullock (1962), Olson (1965), Peltzman (1976), and Becker (1983). Volden and Wiseman (2007) model bargaining between politicians and interest groups in the provision of public and particularistic private benefits from a given budget. Their model illustrates interestgroup pressures on politicians in budget allocations.

expenditures. Singhal (2008) empirically examines the allocation of tobacco-settlement trust funds and how it deviated from initial health investment objectives. 
More empirical research on how long-term political commitments have been secured for regional and national environmental policies and whether these might apply to global policies would be an important contribution. Since the 1970s there has been major expansion of environmental regulation at the federal, state, and local level. Analysis of political support for those policies; how they are affected by uncertainty, differential preferences and perceptions, asymmetric information, and enforcement; what transfers have been required for adoption; and political responses to shifting program costs and benefits would provide valuable insights into the likelihood and durability of international cooperation to address climate change. Differential Preferences and Perceptions of Mitigation Benefits across Countries.

Because leaders of multiple countries must cooperate in confronting global environmental externalities, heterogeneous preferences and perceptions of the problem across countries make it difficult to reach consensus. Preferences and perceptions are affected by the great heterogeneity in baseline economic conditions across countries. Populations differ in per capita incomes, wealth, marginal values of consumption, discount rates, energy intensity, and production units. There are widely-differing views as to what policies countries should take in light of this heterogeneity.

Agarwala $(2010,182,194-8)$ describes the gulf between citizens of developed and developing countries in their views of the GHG externality and who should bear the costs of confronting it. He argues that developed countries must assume the greatest costs because of their historical contributions to GHG stocks, even though populations of developing countries are likely more at risk from climate change and benefit disproportionately from mitigation. Any carbon-cost estimate implies that current populations in developed countries owe compensation in the neighborhood of hundreds of billions of dollars or more to present and future generations 
in developing countries. Agarwala also claims that given high consumption expectations within developing countries, more-than-commensurate reductions are required from consumers in highincome countries if global abatement goals are to be met. Along these lines Aldy et al (2010, 909) suggest that developed countries might bear two-thirds or more of discounted global abatement costs over the next century. Using a global emissions trading scheme to simulate cross-country distributional effects of reaching emissions targets, Jacoby et al (2010, 754-64, 781-2) estimate that compensation to hold $\mathrm{CO}_{2} \mathrm{e}$ concentrations at $450 \mathrm{ppm}$ from the US alone could amount to $\$ 200$ billion in 2020 annually, or 10 times the current US development assistance budget.

Because the social cost of carbon in developed countries like the U.S. is higher than the marginal abatement cost (as reflected in the discounted value of reduced consumption due to the imposition of GHG emission controls) in developing countries like China, it is Pareto-improving for developed countries to compensate developing countries for their abatement efforts. Deshpande and Greenstone $(2010,9)$ estimate that the value of such payments from the U.S. to China could be as high as $\$ 5.3$ trillion. Whether U.S. political interest groups would interpret these payments as Pareto-improving is unclear, however, especially given the magnitudes involved. ${ }^{69}$ There are also thorny and unresolved issues of how these payments would be credibly distributed among members of a heterogeneous population as compensation for the opportunity costs of foregone consumption without creating enormous opportunities for corruption on the part of politicians and bureaucrats of recipient countries.

Differences in per-capita incomes, economic growth, and consumption aspirations within developing nations also affect country positions in international bargaining and treaty

\footnotetext{
${ }^{69}$ Becker et al (2010) have a more cautious assessment of the potential for international collaboration when there are large differences in marginal rates of substitution between current and future consumption across populations in developed and undeveloped countries.
} 
compliance. Abebe and Masur (2010) examine the eastern and western regions of China and argue that climate-change policies that raise energy costs and reduce economic growth in the less-developed west may not be consistent with preserving domestic political stability. Although internationally-funded internal transfers are possible, Abebe and Masur (2010, 342-56, 370-4, 384-5) point to limited data and uncertainty about income growth, energy consumption, and population-growth patterns, as well as to corruption that could make it difficult to adequately compensate residents of western China. In related work Auffhammer and Carson (2008, 237, 244) use Chinese province-level GDP data, population density, industrial composition, and other controls to forecast China's $\mathrm{CO}_{2}$ releases. These authors forecast emissions far higher than those reported elsewhere. Their findings underscore the uncertainty associated with projecting business-as-usual (BAU) emissions in rapidly-growing developing countries where conditions vary and often are not well known by nor under the control of the central government.

Frankel (2010a, 41-9) provides numerical targets for $\mathrm{CO}_{2}$ emissions for all regions across the planet for the $21^{\text {st }}$ century to illustrate how an international agreement might play out. In his framework, developed countries that participated in the Kyoto Agreement adhere to caps consistent with or greater than their Kyoto commitments while the U.S. implements an earlier version of Waxman-Markey legislation (Frankel 2010a, 37-9, 52-57). Leaders of developing countries, such as China, follow BAU paths until threshold levels of per-capita income and/or per-capita emissions are reached, whereupon predesigned tighter caps kick in as they catch up with abatement by developed countries (Frankel 2010a, 33, 58-68). Within these national caps, emission permits are traded in a global market (Frankel 2010a, 68-69; Keohane and Raustiala $2010,382-3$ ). Simulations reveal allowance prices reaching around $\$ 120 /$ ton of carbon prior to 2050, and nearly $\$ 700-\$ 800$ by 2100 (Frankel 2010a, 75-77). 
Because of the critical role of BAU paths in determining when abatement caps become binding for developing countries, Frankel argues that authority should be delegated to an international expert body with BAU estimates updated every decade (Frankel 2010a, 33-6, 50, 63-8). He points to the World Trade Organization (WTO) and the European Economic and Monetary Union as institutional models. These, however, may not be ideal templates. The WTO has no independent enforcement authority ${ }^{70}$ and the European Union incorporates a collection of countries that are far more homogeneous and culturally tied together than is the case for the rest of the world (Ellerman 2010, 115).

The BAU estimation problems demonstrated by Auffhammer and Carson (2008) combined with weak local/regional governance and limited central government authority present challenges for providing data to any regulatory body. McKibbin et al (2010) also examine international cooperation in the presence of varying macroeconomic shocks that could be transmitted across countries through global emission permit trading. ${ }^{71}$ The transmission of such shocks could generate internal political pressure within affected countries to reduce commitments to international abatement efforts.

There is no past experience of global collaboration of the scale required to achieve lasting, broad-based GHG emission reductions where abatement outcomes are uncertain, benefits generally are not appropriable, and the reallocation of rents through differential mitigation regulation across countries is large. Aldy and Stavins $(2010,5)$ point out that approximately 50 rapidly-growing and GHG-emitting developing economies have greater per-capita incomes than the poorest industrialized countries that were targeted for controls under the Kyoto Protocol.

\footnotetext{
${ }^{70}$ www.wto.org.

${ }^{71}$ Heutel (2012) uses a dynamic stochastic general equilibrium real business cycle model to examine the relationship between regulated $\mathrm{CO}_{2}$ emissions and macroeconomic conditions. He finds that optimal policies are procyclical.
} 
Whether multinational fairness norms can hold international collective action together remains unclear (Frankel 2010a, 33, 39, 51, 57).

A variety of mechanisms were included in the Kyoto Protocol to entice the involvement of leaders of developing nations, including the Clean Development Mechanism, whereby developed-country emitters secure lower-cost abatement credits from mitigation investments in developing countries rather than undertaking more costly reduction actions at home (Barrett 2005, 380-2; Newell 2010); ${ }^{72}$ the Global Environment Facility to oversee financial flows from developed to developing countries $;{ }^{73}$ the Least Developed Countries Fund; ${ }^{74}$ the Adaptation Fund $;^{75}$ the Special Climate Change Fund ${ }^{76}$ the Reducing Emissions from Deforestation in Developing Countries program (REDD); ${ }^{77}$ and the Green Climate Fund. ${ }^{78}$ These programs potentially involve very large financial and technological flows from developed to developing countries in exchange for abatement, and as such reflect the underlying property rights distribution defined by the Kyoto Protocol.

Asymmetric information.

The key problem here is gathering accurate data on historical emissions from individual

\footnotetext{
${ }^{72}$ For CDM accounting see $c d m$.unfccc.int/; Joint Implementation (JI) projects among parties in regulated or Annex B countries in http://ji.unfccc.int/index.html. CDM has been criticized for supporting projects that would have been undertaken anyway and for setting up perverse incentives (Agarwala 2010, 187; Bushnell, 2012, 201; Keohane and Raustiala 2010, 376; and Victor (2010, 645; 2011, 77, 90-99). Aldy and Stavins (2012) are more positive.

${ }^{73} \mathrm{http}$ ://unfccc.int/cooperation_and_support/financial_mechanism/items/2807.php, discussed at the COP meeting at Geneva 1996.

${ }^{74}$ http://unfccc.int/cooperation_support/least_developed_countries_portal/ldc fund/items/4723.php, discussed at (COP) meetings of 2001 in Bonn and 2003 in Milan.

${ }^{75} \mathrm{http} / / /$ unfccc.int/cooperation and support/financial_mechanism/adaptation_fund/items/3659.php, discussed at the COP meetings of 2000 in The Hague, 2001 in Bonn and 2008 in Poznan.

${ }^{76} \mathrm{http}: / /$ unfccc.int/cooperation_and_support/financial_mechanism/special_climate change fund/items/3657.php, discussed at the COP meetings in 2001 in Bonn and 2003 in Milan.

${ }^{77}$ http://www.un-redd.org/, discussed at the COP meeting in Montreal 2005 and Bali 2007. A critical analysis of Reducing Emissions from Deforestation in Developing Countries or REDD is provided in Alston and Andersson (2011). Other discussions of REDD's challenges and possibilities are in Myers (2007); Stickler et al. (2009); Taconi (2009); Blom et al (2010); and Busch (2013).

${ }^{78} \mathrm{http} / / /$ unfccc.int/cooperation_and_support/financial_mechanism/green_climate fund/items/5869.php, discussed at the COP 2010 meeting in Cancun and 2011 in Durban.
} 
installations to project the costs of regulation, assign permits allocations (if grandfathering of allowances is used in cap and trade), and to determine compliance targets. Local entities have far more information than do central government regulators. They have incentives to manipulate the data in order to gain greater transfers or exemptions, more emission permits, or demonstrate compliance. There is little analysis of this problem in the literature on GHG emission controls. The primary case that has been examined is the EU ETS. Ellerman and Buchner $(2007,69-77)$ describe the problems of asymmetric and incomplete information at the unit level across member countries that confounded the calculation and distribution of emission allowances across EU countries, particularly in Phase I of the regime.

\section{Enforcement.}

Enforcement is critical for the durability of property rights. If parties do not adhere to a multilateral cooperation agreement, then global mitigation objectives are not met and transaction costs are increased as a new round of negotiations becomes necessary. Global GHG emissionsdetection technologies may be insufficient to identify breaches when there are many sources of the externality that vary in size, location, timing, production technologies, and sectors (Deshpande and Greenstone 2010, 11; Sigman 2012; Borenstein 2012; and Greenstone and Looney 2012, 27). It also is difficult to separate observed unit and sector-level compliance from the effects of business cycles and technology shocks. National economic recessions could mask a lack of compliance that would be revealed during an economic rebound, and new technology could change BAU trajectories and country caps associated with them (Hallegatte et al 2012,2).

There also is the politically-sensitive issue of leakage whereby firms in developed economies move to less-regulated developing economies, or for carbon intensity to increase in developing countries as fossil fuel prices decline following reductions in demand in developed 
economies (Barrett 2005, 383; Bushnell and Mansur 2011). Leakage concerns were behind the Byrd-Hagel Resolution, which passed by a vote of 95-0 in the US Senate in July 1997, requiring the cooperation of developing countries in any future climate treaty beyond Kyoto as a condition for US participation (S. Res $98105^{\text {th }}$ Cong.). Mattoo et al $(2009,2)$ briefly summarize the literature on production leakage due to unilateral cuts in industrial countries. Although they find that aggregate effects appear to be small, there are more substantial sector impacts in energyintensive industries, such as cement, steel, and aluminum. Elliott et al (2012) use a computable general equilibrium model to analyze emission reductions from a carbon tax in industrialized countries and expected carbon leakage.

The major enforcement mechanisms that have emerged in the literature are carbon tariffs and related trade sanctions on non-adhering exporters in international trade (Barrett 1997; Ulph 2001; Houser 2008; Victor 2011, 85; Young 2011, 4). Elliott et al (2012, 3, 21-36) discuss the use of border taxes on carbon-intensive imports and rebates of domestic carbon taxes on exports. Mattoo et al $(2009,3)$ simulate various carbon tax/tariff regimes and find that the least damaging to international trade are those that symmetrically tax exports and imports on their carbon content in domestic production. Metcalf and Weisbach (2009, 40-52) similarly discuss different carbon border-tax effects; measurement problems when fuels and technologies vary across international trading units; and harmonization with existing WTO practices. Frankel (2010b, 503-23) examines four environmental cases of alleged discrimination against foreign products/producers to see how the WTO responded and finds that environmental regulations were not held as discriminatory. He also discusses trade policies to enforce GHG controls and points to the challenge of determining the carbon content of manufactured goods using U.S. production techniques as a guide when factor costs vary sharply worldwide. Frankel suggests 
that trade policy in GHG control be delegated to independent experts and not to politicians, given the amounts at stake and the measurement problems involved. As noted above, more attention to political models and the circumstances when politicians would agree to such delegation is necessary to assess the feasibility of such proposals.

Despite the importance of border taxes and trade sanctions in the GHG policy literature, too-little attention has been paid to the empirical literature on international trade and trade agreements that examines how international agreement was secured on the General Agreement on Tariffs and Trade (GATT) and the World Trade Organization (WTO); what trade policies have worked and which ones have not; and how sensitive the trading framework might be to the use of trade sanctions and carbon tariffs as GHG enforcement mechanisms. The use of trade policy to enforce GHG mitigation could strain the multinational trading structure (Barrett 2005, 382-8; 2010, 246-8; Bown 2004b; Copeland and Taylor 2005; Hufbauer et al 2009; Keohane and Raustiala 2010, 379; Kaufman and Weber 2011).

Eichengreen and Irwin (2009), Irwin and O’Rourke (2011), Mansfield and Milner (2012), and Bordo et al (2013) describe the complicated negotiations in the early $20^{\text {th }}$ century that created the foundations for modern international trade. Most agreements were among representatives of developed countries with relatively similar political, monetary, and economic structures, at least as compared to those of developing countries today. The breakdown of the international trading system during the 1930s is discussed by Irwin (2011). As a response to this breakdown, the GATT was implemented in 1947, lasting until 1994 when it was replaced by the WTO in 1995. Bown (2004a) empirically examines the determinants of country adherence to GATT rules and legal safeguards and non-tariff provisions adopted between 1973 and 1994. Bagwell and Staiger (2011) provide similar empirical analysis of the WTO from 1995-2005. 
Bown (2013) explores the use of temporary trade barriers (TTB), such as safeguard policy (SG), antidumping (AD), and countervailing duties (CVD) that apply to imports from only one country. These are viewed as non-discriminatory by the WTO. Antidumping actions are a close analogy to carbon tariffs because both are designed to level differential costs due to "unfair" production practices or non-compliance. Bown (2013) finds (i) that there is a proliferation of temporary trade barriers; (ii) that developed countries are more likely to use them against exports of developing countries, particularly as counter-cyclical trade responses; and (iii) that they work to counter the benefits of low worldwide tariffs.

The success of the GATT and the WTO is due to the fact that they provide mechanisms through which country leaders can credibly commit to lowering tariffs and other trade barriers, generating broad economic benefits to domestic constituencies that would otherwise have been politically difficult to capture. These benefits are spread via Most-Favored-Nation clauses. Violation by any country results in the loss of tangible benefits, which provides leverage for enforcement (Odell 2006; Hoekman and Mavroidis 2007). Mechanisms like these may not work so well to spread the benefits of carbon tariffs or related trade policies. GHG reduction is a public good and therefore not excludable. Measurement of carbon content, which would be required for sanctions to be implemented, is costly and the potential for protectionism may be high. Accordingly, the scope for carbon tariffs and other trade sanctions to enforce GHG reductions may not be as great as the GHG-policy literature suggests.

In the presence of possible irreversibilities from global externalities, such as catastrophic climate effects of GHG buildup or the ongoing depletion of highly-migratory fish stocks, there is cause for concern when international mitigation agreements cannot be reached. The discussion of bargaining complexities for Category (3) externalities is not meant to be nihilistic, but rather 
to indicate key sources of transaction costs and where attention can be directed most

productively for moving forward. Thinking about transactions costs in a structured way suggests what will be helpful for solving the negotiation problems encountered when heterogeneous interests within and across nations must cooperate in the presence of deep uncertainties about the benefits and costs of mitigation.

In the case of reaching multilateral emission controls, our discussion of transaction costs suggests that mobilizing durable internal political support for significant preemptive action by major developed countries will be difficult at this time. What is needed is a more credible demonstration of the benefits of costly mitigation to populations in those countries as well as to populations in rapidly-developing countries, so that the latter begin limited emissions reductions that gradually become more binding (Frankel 2010a). As discussed earlier, public-opinion surveys suggest that individuals are most concerned about local effects. This suggests that reducing scientific uncertainty about regional climatic reactions to GHG accumulations and associated economic damage functions will have a large payoff. Some of this information may come through observed, harmful localized shifts in weather patterns attributable to global climate change. More positively, however, the reduction in regional scientific uncertainty can come from more research on regional climatic feedbacks from GHG accumulations and their economic consequences. If politically-influential parties in key emitting countries can better perceive the net benefits of cooperation, political leaders will be more likely to commit to long-lasting mitigation policies, such as carbon taxes or cap-and-trade. It will also be easier to devise transfer payments to offset differential preferences and perceptions of the externality, internally and across countries. With more information about regional impacts, country leaders will have a clearer sense of the specific gains to their populations from mitigation; of the corresponding 
willingness-to-pay from key demanders for property rights; and of the transfers necessary both to secure domestic political support and to obtain the collaboration of rapidly-growing countries. Bargaining positions will converge with new, public knowledge about regional costs and benefits. Further, technological innovations (such as satellite monitoring and photography) can make observing and verifying emissions more feasible and will make any agreed-upon international property rights regime more durable. Measurement advances also will make identification of carbon content in products easier when imposing border tariffs to enforce international agreements.

In the case of highly-migratory fish species, scientific advances that reduce uncertainty about the effects of local harvests on global stocks and that help distinguish the effects of environmental fluctuations from harvest also will lower transaction costs and narrow distances among bargaining positions. The primary impediments to international cooperation are differential preferences between existing and new fishing nations, fueled by uncertainty and open entry in the high seas. Local catches may provisionally remain at high levels even as overall stocks plummet. More convincing evidence of the linkages among regional fishing practices, falling global stocks, and related declines in catch-per-unit of effort can promote agreement. Additionally, international law that allows for virtual open access into regional fishing management organizations (RFMOs), particularly by developing countries with limited fishing histories, must be revised to limit entry. Only then will property rights be stable. Restrictions on regional entry into a global resource require compensating transfers. Greater clarity on stock conditions and the economic effects of new harvest pressure from developing countries can facilitate the calculation of such payments. 


\section{Concluding Remarks.}

This review examines collective action to address global environmental externalities. It uses a transaction costs framework to understand why the results are so mixed. Multinational cooperation to mitigate environmental externalities requires that transaction costs be overcome. These transaction costs are low for mobilizing cooperation to protect biodiversity and unique ecosystems from over exploitation. They are somewhat higher in achieving cooperation to limit the international trade in endangered plant and animal species and to constrain the release of gases that harm the stratospheric ozone layer. Even more costly are cooperative efforts for multinational controls on the harvest of highly migratory, valuable fish, such as bluefin tuna. Finally, international cooperation on the reduction of GHG emissions that contribute to global warming involves transaction costs that are higher still.

International cooperation is a contractual process among country leaders to assign property rights that internalize the externality. Property rights are assigned when restrictions are placed on natural resources that otherwise are subject to broad, open-access entry by parties from many nations. Property rights are also established by assigning abatement responsibilities to entities in specified countries to reduce the external effects of production on the natural environment and that assign benefits to various groups across the planet. In either case, mitigation generates rents and cross-country negotiations allocate those rents. Country leaders cooperate in international environmental agreements when it serves influential domestic interests to do so. Specific country constituencies demand that policies be undertaken to reduce externality losses. These policies generate benefits and costs and their levels and distributions depend upon the details of the agreement. The reaction of country constituencies to proposed property rights distributions and the response of country politicians in internal and multinational 
negotiations mold the nature and timing of the property rights that emerge and their effectiveness in abatement.

Four factors raise the transaction costs of assigning property rights via abatement negotiations: (i) scientific uncertainty regarding the benefits and costs of mitigation and the reaction of natural systems to collective efforts; (ii) varying preferences and perceptions across global populations to taking action; (iii) asymmetric information among the parties regarding contributions to the problem, mitigation net benefits, and enforcement; and (iv) a lack of compliance and new entry.

The losses due to resource exploitation under incomplete property rights occur along all spatial dimensions. Rents are saved in many local common-property settings though communal institutions. These are successful because transaction costs are low. Property rights are embodied in community rules that define when and how resources are to be exploited. The local CPR literature defines the conditions that underlie successful collective action. Although these conditions cannot be replicated when externalities expand, they nevertheless define baseline conditions that must be met for cooperation to occur. Even for relatively narrow CPRs, when these conditions are not met, transaction costs rise. An understanding of how property rights over the costs and benefits of mitigation break down in the context of somewhat broader CPRs is therefore useful for the analysis of global externalities. An examination of how higher transaction costs impede agreement in these intermediate settings, such as U.S. oil and gas development and the Maine lobster fishery, sheds light on the likelihood of collective action to address even more challenging and expansive externalities. Scaling localized CPR lessons to global mitigation efforts also is straightforward when multinational action, such as with controls on GHG buildup, involves local actors, as is the case with forest management to promote carbon 
sequestration. If effective linkage is to occur, local institutions and practices must be incorporated in broader actions.

The IEA literature provides direction for understanding when multinational cooperation is likely and when it is not. The general prediction is that collaboration among uniform countries is collectively rational when the stakes are low-there is little gained in the aggregate and little reason for defection or when the benefits of international cooperation are narrowly directed to specific countries. These conditions are broadly consistent with low-transaction costs cases examined above — set asides for national parks and biodiversity, limits on the trade in endangered species (CITES), and controls on the release of CFCs. Transaction costs are greater for achieving controls on the harvest of highly-migratory fish stocks and on GHG emissions, two instances where effective agreements have not generally been forthcoming.

The IEA literature approach is grounded in theoretical modeling, simulation, and laboratory experiments. It has not been an empirical literature. The approach outlined here provides a framework for expanded modeling of international cooperation and for empirical investigation. It focuses on the sources of transaction costs that affect the assignment of property rights in international environmental agreements. Comparative, in-depth, empirical analysis of the wide range of international environmental agreements that encounter varying transaction costs would reveal how those costs were overcome and how doing so affected the structure of the final agreement and the mitigation that was possible. At the same time, empirical research can be better directed by additional conceptual analysis that incorporates transaction costs into models of international environmental externality control. Numerous areas that have been discussed in this review are ripe for research using the four testable implications presented in Section I. 
The review highlights the need for more analysis of the variation in success among international environmental agreements and the role of transaction costs in determining those results: how they influence long-term political commitments to environmental policies; how they affect interest group politics in setting the positions of country leaders in multinational negotiations; how they impact the design and operation of cap-and-trade and other mitigation policies; how they mold development of transfers within and across countries and how those transfers in turn affect the structure and timing of the agreement; how they influence the incentives of national politicians to delegate administration of treaties and covenants and the property rights associated with them to independent agencies; and how they impact treaty enforcement mechanisms, including the use of trade sanctions and carbon tariffs.

Growing international concerns about global environmental externalities, the need for multinational cooperation to address them, and the very uneven record of successfully doing so, suggest that greater attention to the details of the transaction costs encountered may pay important returns. The transaction costs approach better identifies what international mitigation is possible at any point in time. It also indicates what must be done in order to facilitate multinational agreement. Transaction costs are the constraints on what is possible, and what is possible changes as transaction costs are reduced. A focus on the costs of defining property rights makes it clear what can and cannot be accomplished in multilateral efforts to control global environmental externalities. 


\section{References}

Abebe, Daniel, and Jonathan S. Masur. 2010. "International Agreements and Internal Heterogeneity: The 'Two Chinas' Problem.” Virginia Journal of International Law 50 (2): 325-89.

Acheson, James M. 1975. "The Lobster Fiefs: Economic and Ecological Effects of Territoriality in the Maine Lobster Industry." Human Ecology 3: 183-207.

Acheson, James M. 1988. The Lobster Gangs of Maine, Hanover: University Press of New England.

Acheson, James M. 2003. Capturing the Commons: Devising Institutions to Manage the Maine Lobster Industry, Hanover: University Press of New England.

Acheson, James M., and Roy Gardner. 2005."Spatial Strategies and Territoriality in the Maine Lobster Industry." Rationality and Society 17 (3): 309-41.

Adhikari, Bhim, and Jon C. Lovett. 2006. "Institutions and Collective Action: Does Heterogeneity Matter in Community-Based Resource Management?" Journal of Development Studies, 42(3), 426-445.

Agarwala, Ramgopal. 2010. "Towards a Global Compact for Managing Climate Change," in Joseph E. Aldy and Robert N. Stavins, eds, Post-Kyoto International Climate Policy: Implementing Architectures for Agreement, New York: Cambridge University Press, 179-200.

Agnew, David J., John Pearce, Ganapathiraju Pramod, Tom Peatman, Reg Watson, John R. Beddington, and Tony J. Pitcher. 2009. "Estimating the Worldwide Extent of Illegal Fishing." PLoS ONE 4 (2): e4570.

Agrawal, Arun. 2001. "Common Property Institutions and Sustainable Governance of Resources.” World Development 29 (10): 1623-48.

Alcock, Frank. 2010. "Prospects for Use Rights in Tuna Regional Fisheries Management Organizations." in Robin Allen, James Joseph and Dale Squires eds, Conservation and Management of Transnational Tuna Fisheries, Oxford, UK: Wiley-Blackwell, 249-268.

Aldy, Joseph E and Robert N. Stavins, eds. 2007. Architectures for Agreement: Addressing Global Climate Change in the Post-Kyoto World, New York: Cambridge University Press.

Aldy, Joseph E. and Robert N. Stavins, eds. 2010. Post-Kyoto International Climate Policy: Implementing Architectures for Agreement New York: Cambridge University Press.

Aldy, Joseph E. and Robert N. Stavins. 2010. "Introduction." in Joseph E. Aldy and Robert N. Stavins, eds, Post-Kyoto International Climate Policy: Implementing Architectures for Agreement, New York: Cambridge University Press, 1-30.

Aldy, Joseph E. and Robert N. Stavins. 2012. "Climate Negotiators Create and Opportunity for Scholars," Science 337: 1043-4.

Aldy, Joseph E., Alan J. Krupnick, Richard G. Newell, Ian W.H. Parry, and William A. Pizer. 2010. "Designing Climate Mitigation Policy." Journal of Economic Literature 48 (4): 903-34.

Allen, Douglas W. 1991. "What are Transaction Costs?" Research in Law and Economics 14: 118.

Allen, Douglas W. 2000. "Transaction Costs." in Boudewijn Bouckaert and Gerrit De Geest, eds., The Encyclopedia of Law and Economics, Vol.1. Cheltenham: Edward Elgar, 893926. 
Allen, Robin, William Bayliff, James Joseph, and Dale Squires. 2010. "The Benefits and Costs of Transformation of Open Access on the High Seas," in Conservation and Management of Transnational Tuna Fisheries, edited by Robin Allen, James Joseph and Dale Squires, Oxford, UK: Wiley-Blackwell, 65-86.

Allen, Robin, James Joseph, and Dale Squires eds. 2010. Conservation and Management of Transnational Tuna Fisheries, Ames: Wiley-Blackwell.

Alston, Lee J. and Krister Andersson. 2011. "Reducing Greenhouse Gas Emissions by Forest Protection: The Transaction Costs of Implementing REDD." Climate Law 2: 281-89.

Alston, Lee J., Krister Andersson, and Stephen M.Smith. 2013. "Payments for Environmental Services," Annual Review of Resource Economics, forthcoming.

Anesi, Vincent. 2006. "Earmarked Taxation and Political Competition," Journal of Public Economics 90: 679-701.

Ansolabehere, Stephen D., and David M. Konisky. 2009. "Public Attitudes toward Construction of New Power Plants." Public Opinion Quarterly 73 (3): 566-77.

Ansolabehere, Stephen D., and David M. Konisky. 2012. "The American Public's Energy Choice" Daedalus 141 (2): 61-71.

Archer, David. 2007. Global Warming: Understanding the Forecast. Malden, MA: Blackwell.

Archer, David. 2009. The Long Thaw. Princeton: Princeton University Press.

Arnason, Ragnar, Kieran Kelleher, and Rolf Willmann. 2009. The Sunken Billions: The Economic Justification for Fisheries Reform. Washington D.C.: The World Bank and FAO.

Asheim, Geir B., Camilla Bretteville Froyn, Jon Hovi, and Fredric C. Menz. 2006. "Regional Versus Global Cooperation for Climate Control." Journal of Environmental Economics and Management 51: 93-109.

Asheim, Geir B. and Bjart Holtsmark. 2009. "Renegotiation-Proof Climate Agreements with Full Participation: Conditions for Pareto-Efficiency." Environmental and Resource Economics 43: 519-533.

Auffhammer, Maximilian, Bernard J. Morzuch, and John K. Stranlund. 2005. "Production of Chlorofluorocarbons in Anticipation of the Montreal Protocol." Environmental and Resource Economics 30: 377-91.

Auffhammer, Maximillian, and Richard T. Carson. 2008. "Forecasting the Path of China's $\mathrm{CO}_{2}$ Emissions Using Province-Level Information." Journal of Environmental Economics and Management 55(3): 229-47.

Bagwell, Kyle and Robert W. Staiger. 2011. "What do Trade Negotiators Negotiate about? Empirical Evidence from the World Trade Organization. American Economic Review 101(4): 1238-73.

Bailey, Elizabeth M., Severin Borenstein, James Bushnell, Frank A. Wolak, and Matthew Zaragoza-Watkins. 2013. "Forecasting Supply and Demand Balance in California's Greenhouse Gas Cap and Trade Market.” Working paper. Palo Alto: Program on Energy and Sustainable Development, Stanford University.

Baland, Jean-Marie, and Jean-Philippe Platteau. 1996. Halting Degradation of Natural Resources : Is There a Role for Rural Communities ? Oxford: Oxford University Press and FAO.

Baland, Jean-Marie, and Jean-Philippe Platteau.1997. "Wealth Inequality and Efficiency in the Commons. Part I: The Unregulated Case.” Oxford Economic Papers 49: 451-82. 
Baland, Jean-Marie, and Jean-Philippe Platteau. 1998. Wealth Inequality and Efficiency in the Commons. Part II: The Regulated Case." Oxford Economic Papers 50: 1-22.

Balton, David A. 2001. "The Bering Sea Doughnut Hole Convention: Regional Solution, Global Implications," in Olav Schram Stokke, ed. 2001. Governing High Seas Fisheries: The Interplay of Global and Regional Regimes. New York: Oxford University Press 143-77.

Barbier, Edward B., Joanne C. Burgess, Timothy M. Swanson, and David W. Pearce. 1990. Elephants, Economics, and Ivory London: Earthscan Publications.

Bardhan, Pranab K. 2000. "Irrigation and Cooperation: An Empirical Analysis of Cooperation on Irrigation in South India." Economic Development and Cultural Change 48: 847-65.

Barkin, J. Samuel. 2004. "Time Horizons and Multilateral Enforcement in International Cooperation.” International Studies Quarterly 48 (2): 363-82.

Barrett, Scott. 1994. "Self-Enforcing International Environmental Agreements." Oxford Economic Papers 46: 878-94.

Barrett, Scott. 1997. "The Strategy of Trade Sanctions in International Environmental Agreements," Resource and Energy Economics 19(4): 345-61.

Barrett, Scott. 1999. "A Theory of Full International Cooperation,” Journal of Theoretical Politics, 11: 519-41.

Barrett, Scott. 2001. "International Cooperation for Sale.” European Economic Review, 45 (10):1835-50.

Barrett, Scott. 2002. “Consensus Treaties.” Journal of Institutional and Theoretical Economics 158: 529-547.

Barrett, Scott. 2005. Environment and Statecraft: The Strategy of Environmental Treaty-Making, Oxford: Oxford University Press paperback edition.

Barrett, Scott. 2007. Why Cooperate: The Incentive to Supply Global Public Goods. New York: Oxford University Press.

Barrett, Scott. 2010. "A Portfolio of Climate Treaties." in Joseph E. Aldy and Robert N. Stavins, eds, Post-Kyoto International Climate Policy: Implementing Architectures for Agreement, New York: Cambridge University Press, 240-72.

Barzel, Yoram.1982. "Measurement Costs and the Organization of Markets." Journal of Law and Economics 25 (1): 27-48.

Barzel, Yoram. 1985. “Transaction Costs: Are they Just Costs?," Journal of Institutional and Theoretical Economics 141: 4-16.

Barzel, Yoram. 1997. Economic Analysis of Property Rights. $2^{\text {nd }}$ ed. New York: Cambridge University Press.

Baumol, William. J. 1972. "On Taxation and the Control of Externalities." American Economic Review 62 (3): 307-22.

Becker, Gary S. 1983. "A Theory of Competition Among Pressure Groups for Political Influence.” Quarterly Journal of Economics 98 (3): 371-400.

Becker, Gary S., Kevin M. Murphy, and Robert H. Topel. 2010. "On the Economics of Climate Policy,” working paper 234, Chicago: University of Chicago George J. Stigler Center for the Study of the Economy and the State.

Beddington, John. R., David. J. Agnew and Colin W. Clark. 2007. "Current Problems in the Management of Marine Fisheries." Science 316: 1713-6.

Benedict, Richard E. 1991. Ozone Diplomacy: New Directions in Safeguarding the Planet, Cambridge: Harvard University Press. 
Benegal, Salil and Lyle Scruggs. 2012. American Exceptionalism or Economic Erosion: What Explains Changing Attitudes to Global Warming? working paper, Department of Political Science, University of Connecticut.

Bergstrom, Theodore C. 2010. "The Uncommon Insight of Elinor Ostrom," Scandinavian Journal of Economics 112 (2): 245-61.

Berkes, Fikret, David Feeny, Bonnie McCay, and James M. Acheson. 1989."The Benefits of the Commons," Nature 340: 91-93.

Beron, Kurt J., James C. Murdoch, and Wim P. M. Vijverberg. 2003. "Why Cooperate? Public Goods, Economic Power, and the Montreal Protocol." The Review of Economics and Statistics 85 (2): 286-97.

Bickers, Kenneth N. and Robert M. Stein. 2000. "The Congressional Pork Barrel in a Republican Era," Journal of Politics, 62 (4): 1070-86.

Bjørndal, Trond and Ana Brasão. 2006. "The East Atlantic Bluefin Tuna Fisheries: Stock Collapse or Recovery?" Marine Resource Economics 21:193-210.

Bjørndal, Trond, Veijo Kaitala, Marko Lindroos, and Gordon R. Munro. 2000. "The Management of High Seas Fisheries." Annals of Operations Research 94 (1-4): 183-96.

Blom, Benjamin, Terry Sunderland, and Daniel Murdiyarso. 2010. "Getting REDD to Work Locally: Lessons Learned from Integrated Conservation and Development Projects", Environmental Science and Policy 13(2): 164-72.

Bordo, Michael D., Owen F. Humpage and Anna J. Schwartz. 2013. Strained Relations: U.S. Monetary Policy and Foreign-Exchange Operations in the Twentieth Century, http://www.nber.org/chapters/c12908, forthcoming University of Chicago Press and NBER.

Borenstein, Severin. 2012. "Markets for Anthropogenic Carbon with the Larger Carbon Cycle," in Don Fullerton and Catherine Wolfram, eds, The Design and Implementation of US Climate Policy, Chicago: NBER and University of Chicago Press, 93-102.

Bown, Chad P. 2004a. "Trade Disputes and the Implementation of Protection under the GATT: An Empirical Assessment.” Journal of International Economics 62: 263-94.

Bown, Chad P. 2004b. "On the Economic Success of GATT/WTO Dispute Settlement," The Review of Economics and Statistics 86 (3): 811-23.

Bown, Chad P. 2013. "How Different Are Safeguards from Antidumping? Evidence from US Trade Policies toward Steel.” Review of Industrial Organization 42(4): 449-81.

Brett, Craig and Michael Keen. 2000. "Political Uncertainty and the Earmarking of Environmental Taxes," Journal of Public Economics 75: 315-40.

Brown, Gardner. Jr. and David F. Layton. 2001. A Market Solution for Preserving Biodiversity: the Black Rhino. Cambridge: Cambridge University Press.

Brunner, Steffen, Christian Flachsland, and Robert Marschinski. 2012. "Credible Commitment in Carbon Policy," Climate Policy 12 (2): 255-271.

Buchanan, James M. and William Craig Stubblebine. 1962. "Externality," Economica 29(116): 371-84.

Buchanan, James M. and Gordon R. Tullock. 1962. The Calculus of Consent, Ann Arbor: University of Michigan Press.

Bulte, Edwin H. and G. Cornelis van Kooten. 1999. "Economics of Antipoaching Enforcement and the Ivory Trade Ban," American Journal of Agricultural Economics 81 (2): 453-66.

Bulte, Erwin H. and Edward B. Barbier. 2005. "Trade and Renewable Resources in a SecondBest World: An Overview.” Environmental and Resource Economics 30(4): 423-63. 
Busch, Jonah. 2013. "Supplementing REDD+ with Biodiversity Payments: The Paradox of Paying for Multiple Ecosystem Services," Land Economics 89(4), forthcoming.

Bushnell, James B. and Erin J. Mansur. 2011. "Vertical Targeting and Leakage in Carbon Policy," American Economic Review, Papers and Proceedings 10 (3): 263-7.

Carraro, Carlo, and Domenico Siniscalco. 1993. "Strategies for the International Protection of the Environment." Journal of Public Economics 52: 309-328.

Casey, Keith E., Christopher M. Dewees, Bruce R. Turris, and James E. Wilen. 1995. "The Effects of Individual Vessel Quotas in the British Columbia Halibut Fishery." Marine Resource Economics 10: 211-230.

Cash, David W., W. Neil Adger, Fikret Berkes, Po Garden, Louis Lebel, Per Olsson, Lowell Pritchard, and Oran Young. 2006. "Scale and Cross-Scale Dynamics: Governance and Information in a Multilevel World." Ecology and Society 11(2): 8. URL: http://www.ecologyandsociety.org/vol11/iss2/art8/.

Chander, Parkash and Henry Tulkens. 1995. "A Core-Theoretic Solution for the Design of Cooperative Agreements on Transfrontier Pollution." International Tax and Public Finance 2: 279-293.

Chander, Parkash and Henry Tulkens. 1997. The Core of an Economy with Multilateral Environmental Externalities. International Journal of Game Theory 26: 379-401.

Chander, Parkash and Henry Tulkens. 2008. Cooperation, Stability, and Self-Enforcement in International Environmental Agreements: A Conceptual Discussion," in Roger Guesnerie and Henry Tulkens eds., The Design of Climate Policy, CESifo Seminar Series. Cambridge: MIT Press.

Chermak, Janie M., and Kate Krause. 2002. " Individual Response, Information, and Intergenerational Common Pool Problems." Journal of Environmental Economics and Management 43 (1): 47-70.

Cheung, Steven N.S. 1970. "The Structure of a Contract and the Theory of a Non-Exclusive Resource." Journal of Law and Economics 13 (1): 49-70.

Child, Brian, and Martha West Lyman. 2005. Natural Resources as Community Assets: Lessons from Two Continents. Madison: Sand County Foundation

Christy, Francis, T., Jr. 1973. "Fisherman Quotas: A Tentative Suggestion for Domestic Management." Occasional Paper No. 19 of the Law of the Sea Institute, University of Rhode Island.

Clemencon, Raymond. 2008. "The Bali Road Map: A First Step on the Difficult Journey to a Post-Kyoto Protocol Agreement," Journal of Environment and Development 17 (1): 70 94.

Coase, Ronald. 1960. "The Problem of Social Cost." Journal of Law and Economics 3: 1-44.

Coase, Ronald. 1992. "The Institutional Structure of Production", American Economic Review 82 (4): 713-719.

Convention on International Trade in Endangered Species of Wild Fauna and Flora (CITES). 2010. "Summary record of the eighth session of Committee I." Fifteenth Meeting of the Conference of the Parties (CoP15). Doha, Qatar, 13-25 March 2010, http://www.cites.org/eng/cop/15/sum/E15-Com-I-Rec08.pdf. http://www.cites.org/eng/cop/15/sum/index.shtml 
Cooper, Richard N. 1989. "International Cooperation in Public Health as a Prologue to Macroeconomic Cooperation.” in Richard N. Cooper, Barry Eichengreen, C. Randall Henning, Gerald Holtham, and Robert D. Putnam, eds. Can Nations Agree? Issues in International Economic Cooperation. Washington, D.C.: Brookings Institution. 178-254.

Cooper, Richard N. 1995. "The Coase Theorem and International Economic Relations." Japan and the World Economy. 7:29-44.

Cooper, Richard N. 2010. "The Case for Charges on Greenhouse Gas Emissions," in Joseph E. Aldy and Robert N. Stavins, eds, Post-Kyoto International Climate Policy: Implementing Architectures for Agreement, New York: Cambridge University Press, 151-78.

Copeland, Brian R. and M. Scott Taylor. 2005. "Free Trade and Global Warming: A Trade Theory View of the Kyoto Protocol," Journal of Environmental Economics and Management 49 (2): 205-234.

Cox, Michael, Gwen Arnold, and Sergio Villamayor Tomás. 2010. A Review of Design Principles for Community-Based Natural Resource Management. Ecology and Society 15(4): 38-52, http://www.ecologyandsociety.org/vol15/iss4/art38.

Creti, Anna, Pierra-André Jouvet, and Valérie Mignon. 2012. "Carbon Price Drivers: Phase I Versus Phase II Equilibrium?" Energy Economics 34: 327-34.

Crook, John R. 2010. U.S. "Efforts to Gain CITES Protection for Atlantic Bluefin Tuna, Sharks, and Polar Bears Unsuccessful." The American Journal of International Law 104 (2): 28990.

Crothers, G.T. (Stan) and Lindie Nelson. 2007. "High Seas Fisheries Governance: A Framework for the Future?" Marine Resource Economics 21: 341-53.

Cullis-Suzuki, Sarika and Daniel Pauly. 2010. "Failing the High Seas: A Global Evaluation of Regional Fisheries Management Organizations.” Marine Policy 34: 1036-42.

Dahlman, Carl.1979. "The Problem of Externality." Journal of Law and Economics 22: 141-62.

d'Aspremont, Claude, Alexis Jacquemin, Jean Jaskold Gabszewicz and John A. Weymark. 1983. "On the Stability of Collusive Price Leadership," Canadian Journal of Economics, 16 (1):17-25.

Donsimoni, M. P., Nicholas S. Economides, and Herakles M. Polemarcharkis.1986. "Stable Cartels," International Economic Review, 27 (2): 317-27.

Dayton-Johnson, Jeff. 2000a. "Choosing Rules to Govern the Commons: A Model with Evidence from Mexico" Journal of Economic Behavior and Organization 42: 19-41.

Dayton-Johnson, Jeff. 2000b. "Determinants of Collective Actions on the Local Commons: A Model with Evidence from Mexico." Journal of Development Economics 62: 81-208.

Dayton-Johnson, Jeff, and Pranab K. Bardhan. 2002. "Inequality and Conservation on the Local Commons: A Theoretical Exercise". Economic Journal 112: 577-602.

Deacon, Robert T., Dominic P. Parker, and Christopher Costello. 2013. "Reforming Fisheries: Lesson from a Self-Selected Cooperative," Journal of Law and Economics, 56(1): 83125.

Dellink, Rob and Michael Finus. 2012."Uncertainty and Climate Treaties: Does Ignorance Pay?" Resource and Energy Economics 34(4): 565-84.

DeMeza, David. 1998. "Coase Theorem." In The New Palgrave Dictionary of Economics and The Law. P. Newman, ed. New York: Macmillan, Vol. 1: 1270-82.

Demsetz, Harold.1967. "Toward a Theory of Property Rights." American Economic Review 57: 347-59. 
Demsetz, Harold. 1968. "The Cost of Transacting." Quarterly Journal of Economics 82 (1): 33 53.

Deschênes, Olivier. 2012b. "Climate Policy and Labor Markets," in Don Fullerton and Catherine Wolfram, eds, The Design and Implementation of US Climate Policy, Chicago: NBER and University of Chicago Press, 37-48.

Deshpande, Manasi and Michael Greenstone. 2011. "Comment on 'On the Economics of Climate Policy': Is Climate Change Mitigation the Ultimate Arbitrage Opportunity?" The B.E. Journal of Economic Analysis and Policy 10.2. Article 20; http//hdl.handle.net/1721.1/71249.

Devine, Jennifer A., Krista D. Baker, and Richard L. Haedrich. 2006. "Deep-Sea Fishes Qualify as Endangered." Nature 439 (7072): 29.

Dimitrov, Radoslav S. 2006. Science and International Environmental Policy: Regimes and Nonregimes in Global Governance. Lanham: Rowman and Littlefield.

Duarte, Clara Costa, Ana Brasão, Pedro Pintassilgo. 2000. "Management of Northern Atlantic Bluefin tuna: An application of C-Games." Marine Resource Economics 15 (1):21-36.

Eichengreen, Barry and Douglas Irwin. 2009."Exchange Rates and Economic Recovery in the 1930s," Journal of Economic History 45, 925-946.

Ellerman, A. Denny. 2010. “The EU Emission Trading Scheme: A Prototype Global System?” in Joseph E. Aldy and Robert N. Stavins, eds, Post-Kyoto International Climate Policy: Implementing Architectures for Agreement, New York: Cambridge University Press, 88118.

Ellerman, A. Denny and Barbara K. Buchner. 2007. "The European Union Emissions Trading Scheme: Origins, Allocation, and Early Results." Review of Environmental Economics and Policy 1(1): 66-87.

Elliott, Joshua, Ian Foster, Sam Kortum, Gita Khun Jush, Todd Minson, and David Weisbach, 2012, "Unilateral Carbon Taxes, Border Tax Adjustments, and Carbon Leakage," University of Chicago Law School, Institute for Law and Economics working paper 600, 2nd series.

Ellis, Richard. 2008. “The Bluefin Tuna in Peril.” Scientific American 298: 70-77.

Enders, Alice and Amelia Porges. 1992. "Successful Conventions and Conventional Success: Saving the Ozone Layer." In Kym Anderson and Richard Blackhurst, eds. The Greening of World Trade Issues. New York: Harvester Wheatsheaf, 130-44.

Farrell, Joseph, and Eric Maskin. 1989. "Renegotiation in Repeated Games." Games and Economic Behavior 1: 327-360.

Faysse, Nicolas. 2005. "Coping with the Tragedy of the Commons: Game Structure and Design of Rules.” Journal of Economic Surveys 19(2): 239-61.

Fehr, Ernst and Klaus M. Schmidt. 1999. "A Theory of Fairness, Competition, and Cooperation." Quarterly Journal of Economics 114 (3): 817 -68.

Fehr, Ernst and Simon Gächter. 2000. Cooperation and Punishment in Public Goods Experiments. American Economic Review, 90(4): 980-94.

Finus, Michael. 2001. Game Theory and International Environmental Cooperation. Cheltenham: Edward Elgar.

Finus, Michael and Pedro Pintassilgo. 2013. "The Role of Uncertainty and Learning for the Success of International Climate Agreements." Journal of Public Economics, 103: 29-43.

Fischer, Carolyn. 2004. "The Complex Interactions of markets for Endangered Species Products.” Journal of Environmental Economics and Management 48(2): 926-53. 
Food and Agriculture Organization of the United Nations (FAO). 1995. Code of Conduct for Responsible Fisheries. Rome: FAO.

Food and Agriculture Organization of the United Nations (FAO). 2002. Report of the NorwayFAO Expert Consultation on the Management of Shared Fish Stocks. Bergen, Norway, 710 October. FAO Fisheries Report. No. 695. Rome: FAO.

Food and Agriculture Organization of the United Nations (FAO). 2010. The State of World Fisheries and Aquaculture 2010. Rome: FAO Fisheries and Aquaculture Department.

Food and Agriculture Organization of the United Nations (FAO). 2012. The State of World Fisheries and Aquaculture 2012. Rome: FAO Fisheries and Aquaculture Department.

Fox, Kevin J., R. Quentin Grafton, James Kirkley, and Dales Squires. 2003. "Property Rights in a Fishery: Regulatory Change and Firm Performance." Journal of Environmental Economics and Management 46: 156-77.

Frankel, Jeffrey A. and Paul Romer. 1999. "Does Trade cause Growth?" American Economic Review 89 (3): 379-99.

Frankel, Jeffrey A. 2010a. "An Elaborated Proposal for a Global Climate Policy Architecture: Specific Formulas and Emission Targets for All Countries in All Decades," in Joseph E. Aldy and Robert N. Stavins, eds., Post-Kyoto International Climate Policy: Implementing Architectures for Agreement, New York: Cambridge University Press, 31-87.

Frankel, Jeffrey A. 2010b. "Global Environment and Trade Policy," in Joseph E. Aldy and Robert N. Stavins, eds, Post-Kyoto International Climate Policy: Implementing Architectures for Agreement, New York: Cambridge University Press, 493-529.

Fri, Robert W. and Stephen Ansolabehere. 2012. "The Alternative Energy Future: Challenges for Technological Change," Daedalus 141(2): 5-9.

Fromentin Jean-Marc and Joseph Powers. 2005. "Atlantic Bluefin Tuna: Population Dynamics, Ecology, Fisheries and Management," Fish and Fisheries 6(4), 281-306.

Fromentin, Jean-Marc. 2010. "The Fate of Atlantic Bluefin Tuna." Science 327(March):5971.

Froyn, Camilla Bretteville, and Jon Hovi. 2008. "A Climate Agreement With Full Participation." Economics Letters 99: 317-319.

Fullerton, Don and Catherine Wolfram, eds, The Design and Implementation of US Climate Policy, Chicago: NBER and University of Chicago Press.

Gardner, Roy, Andrew Herr, Elinor Ostrom, and James A. Walker. 2000. "Power and Limitations of Proportional Cutbacks in Common-Pool Resources." Journal of Development Economics. 62: 515-33.

Gehring, Thomas and Eva Ruffing. 2008. "When Arguments Prevail Over Power: The CITES Procedure for the Listing of Endangered Species." Global Environmental Politics 8.2 (2008): 123-148.

Gibson, Clark C., John T. Williams, and Elinor Ostrom. 2005. "Local Enforcement and Better Forests." World Development 33 (2): 273-284.

Gillett, Robert. 2010. Marine Fishery Resources of the Pacific Islands. FAO Fisheries and Aquaculture Technical Paper. No. 537. Rome, FAO.

Gilligan, Michael J. 2010. "The Transactions Costs Approach to International Institutions," Manuscript, Department of Politics, New York University, http://as.nyu.edu/docs/IO/2601/TransactionsCostsApproach.pdf.

Gordon, H. Scott. 1954. "The Economic Theory of a Common-Property Resource: The Fishery" Journal of Political Economy 62 (2): 124-42. 
Goulder, Lawrence H. 2013. "Markets for Pollution Allowances: What Are the (New) Lessons? Journal of Economic Perspective 27(1): 87-102.

Goulder, Lawrence H. and Ian W. H. Parry. 2008. "Instrument Choice in Environmental Policy." Review of Environmental Economics and Policy 2 (2): 152-74.

Grafton, R. Quentin, Dale Squires, and Kevin J. Fox. 2000. "Private Property and Economic Efficiency: A Study of a Common-Pool Resource." Journal of Law and Economics 43 (2): 679-713.

Grafton, R. Quentin, Rögnvaldur Hannesson, Bruce Shallard, Daryl R. Sykes, and Joseph Terry. 2010. "The Economics of Allocation in Tuna Regional Fisheries Management Organizations," in Conservation and Management of Transnational Tuna Fisheries, edited by Robin Allen, James Joseph and Dale Squires, Oxford, UK: WileyBlackwell, 155-62.

Greenstone, Michael and Adam Looney. 2012. "Paying Too Much for Energy? The True Costs of Our Energy Choices," Daedalus 141(2): 10-30.

Haag, Matthew, and Roger Lagunoff. 2007. "On the Size and Structure of Group Cooperation." Journal of Economic Theory 135 (1), 68-89.

Hahn, Robert W. 2009. "Greenhouse Gas Auctions and Taxes: Some Political Economy Considerations." Review of Environmental Economics and Policy 3(2): 167-88.

Hallegatte, Stéphane, Ankur Shah, Robert Lempert, Casey Brown, and Stuart Gill. 2012. "Investment Decision Making Under Deep Uncertainty: Application to Climate Change," Policy Research Working Paper 6193, WPS6193, Sustainable Development Network, Washington DC: World Bank.

Hallman, Brian, Scott Barrett, Raymond P. Clarke, James Joseph, and Dale Squires. 2010. "Limited Access in Transnational Tuna Fisheries," in Conservation and Management of Transnational Tuna Fisheries, edited by Robin Allen, James Joseph and Dale Squires, Oxford, UK: Wiley-Blackwell, 195-214.

Hannesson, Rögnvaldur. 2004. The Privatization of the Oceans. Cambridge: The MIT Press.

Hannesson, Rögnvaldur. 2010. "The Coalition of the Willing: Effect of Country Diversity on an Environmental Treaty Game." The Review of International Organizations 5(4): 461-74.

Hardin, Garrett. 1968. "The Tragedy of the Commons.” Science 162: 1243-8.

Harstad, Bård 2012. "Climate Contracts: A Game of Emissions, Investments, Negotiations, and Renegotiations," Review of Economic Studies 79(4), 1527-57.

Heller, Michael. 1998. "The Tragedy of the Anticommons: Property in the Transition from Marx to Markets." Harvard Law Review 111(3): 621-88.

Helm, Dieter. 2008. "Climate-Change Policy: Why Has So Little Been Achieved?" Oxford Review of Economic Policy, 24 (2) 211-38.

Heutel, Garth. 2012. "How Should Environmental Policy Respond to Business Cycles? Optimal Policy Under Persistent Productivity Shocks.” Review of Economic Dynamics 15: 244-64.

Herrmann, Mark and Keith Criddle. 2006. "An Econometric Market Model for the Pacific Halibut Fishery." Marine Resource Economics 21: 129-58.

Hoekman, Bernard M. and Petros C. Mavroidis. 2007. The World Trade Organization: Law, Economics and Politics. London: Routledge.

Hoel, Michael and Kirsten Schneider .1997. "Incentives to Participate in an International Environmental Agreement.” Environment and Resource Economics. 9 (2): 154-170. 
Hollick, Ann L. and Richard N. Cooper. 1997. “Global Commons: Can They Be Managed?” In Partha Dasgupta, Karl-Göran Mäler, and Alessandro Vercelli, eds. The Economics of Transnational Commons, Oxford: Clarendon Press, 141-71.

Houser, Trevor. 2008. Leveling the Carbon Playing Field: International Competition and US Climate Policy Design. Washington, DC: Peterson Institute for International Economics.

Horan, Richard D. and Jason F. Shogren. 2003. "Elephants: Comment." American Economic Review 93(4): 1437-45.

Hufbauer, Gary Clyde, Steve Charnovitz and Jisun Kim. 2009. Global Warming and the World Trading System. Washington, DC: Peterson Institute for International Economics.

International Commission for the Conservation of Atlantic Tunas (ICCAT). 2008. Report of the 2008 Atlantic Bluefin Tuna Stock Assessment Session (Sept. 29-Oct. 3, 2008).

International Commission for the Conservation of Atlantic Tunas (ICCAT). 2011. "Report of the 2010 Atlantic Bluefin Tuna Stock Assessment Session (Madrid, Spain - September 6 to 12, 2010)." ICCAT Collective Volume of Scientific Papers 66(2): 505-714.

International Commission for the Conservation of Atlantic Tunas (ICCAT). 2012. Report for Biennial Period, 2010-2011, Part II, Vol. 2. Madrid, Spain.

Irwin, Douglas A. 2011. Trade Policy Disaster: Lessons from the 1930s. Cambridge: MIT Press. Irwin, Douglas A and Kevin H. O'Rourke. 2011. "Coping with Shocks and Shifts: The Multilateral Trading System in Historical Perspective.”NBER Working Paper w17598, Cambridge, MA.

Jacoby, Henry D., Mustafa H. Babiker, Sergey Paltsev, and John M. Reilly. 2010. "Sharing the Burden of GHG Reductions," in Joseph E. Aldy and Robert N. Stavins, eds, Post-Kyoto International Climate Policy: Implementing Architectures for Agreement, New York: Cambridge University Press, 753-85.

Jaffe, Judson and Robert N. Stavins. 2010. "Linkage of Tradable Permit Systems in International Climate Policy Architecture," in Joseph E. Aldy and Robert N. Stavins, eds, Post-Kyoto International Climate Policy: Implementing Architectures for Agreement, New York: Cambridge University Press, 119-50.

Johnson, Ronald N. and Gary D. Libecap. 1982. Contracting Problems and Regulation: The Case of the Fishery." American Economic Review 72 (5):1005-22.

Johnson, Scott L. and David M. Pekelney. 1996. "Economic Assessment of the Regional Clean Air Incentives Market: A New Emissions Trading Program for Los Angeles." Land Economics 72(3): 277-297.

Joseph, James, Dale Squires, William Bayliff, and Theodore Groves. 2010. "Addressing the Problem of Excess Fishing Capacity in Tuna Fisheries," in Conservation and Management of Transnational Tuna Fisheries, edited by Robin Allen, James Joseph and Dale Squires, Oxford, UK: Wiley-Blackwell, 11-38.

Kaffine, Daniel T. and Christopher J. Costello. 2010. "Unitization of Spatially Connected Renewable Resources.” NBER Working Paper 16338.

Kahn, Matthew E. 2007. "Do Greens Drive Hummers or Hybrids? Environmental Ideology as a Determinant of Consumer Choice," Journal of Environmental Economics and Management 54(2): 129-45.

Kahn, Matthew E. and Matthew J. Kotchen. 2010. "Environmental Concern and the Business Cycle: The Chilling Effect of Recession." NBER Working Paper 16241.

Kaufman, Christine and Rolf H. Weber. 2011. "Carbon-Related Border Tax Adjustment: Mitigating Climate Change or Restricting International Trade?" World Trade Review 10 
(4): 497-525.

Keohane, Robert O. and Elinor Ostrom, eds. 1995. Local Commons and Global Interdependence: Heterogeneity and Cooperation in Two Domains London: Sage Publications.

Keohane, Nathaniel O. 2009. "Cap-and-Trade, Rehabilitated: Using Tradable Permits to Control Greenhouse Gases.” Review of Environmental Economics and Policy 3(1): 42-62.

Keohane, Robert O. and Kal Raustiala. 2010. "Toward a Post-Kyoto Climate Change Architecture: A Political Analysis," in Joseph E. Aldy and Robert N. Stavins, eds, PostKyoto International Climate Policy: Implementing Architectures for Agreement, New York: Cambridge University Press, 372-402.

Kerr, Richard A. 2001. "Rising Global Temperature, Rising Uncertainty." Science 292 (5515): 192-4.

Kolstad, Charles D. 1996 a. "Fundamental Irreversibilities in Stock Externalities." Journal of Public Economics, 60(2): 221-33.

Kolstad, Charles D. 1996 a. "Fundamental Irreversibilities in Stock Externalities." Journal of Public Economics, 60(2): 221-33.

Kolstad, Charles D. 1996b. "Learning and Stock Effects in Environmental Regulation; the Case of Greenhouse Gas Emissions." Journal of Environmental Economics and Management 31 (1): 1-18.

Kolstad, Charles D. 2007. "Systematic Uncertainty in Self-Enforcing International Environmental Agreements.” Journal of Environmental Economics and Management 53(1): 68-79.

Kolstad, Charles D. 2010. "Equity, Heterogeneity and International Environmental Agreements," B.E. Journal of Economic Analysis and Policy 10(2).http://ideas.repec.org/a/bpj/bejeap/v10y2010i2n3.html.

Kolstad, Charles D. 2011. "Public Goods Agreements with Other-Regarding Preferences," NBER Working Paper No. 17017.http://www.nber.org/papers/w17017.

Kolstad, Charles D. and Alistair Ulph. 2008. "Learning and International Environmental Agreements," Climatic Change 89: 125-41.

Kolstad, Chares D. and Alistair Ulph. 2011. "Uncertainty, Learning and Heterogeneity in International Environmental Agreements." Environmental and Resource Economics, 50(3): 389-403.

Korman, Seth. 2011. "International Management of a High Seas Fishery: Political and PropertyRights Solutions and the Atlantic Bluefin." Virginia Journal of International Law 51 (3): 697-748.

Kotchen, Matthew J. and Michael R. Moore (2007a). "Private Provision of Environmental Public Goods: Household Participation in Green-Electricity Programs." Journal of Environmental Economics and Management 53 (1): 1-16.

Kotchen, Matthew J. and Michael R. Moore (2007b). "Conservation from Voluntary Restraint to a Voluntary Price Premium." Environmental Resource Economics 40: 195-215.

Kremer, Michael and Charles Morcom. 2000. "Elephants." The American Economic Review 90 (1):212-34.

Krutilla, Kerry and Rachel Krause. 2010. "Transaction Costs and Environmental Policy: An Assessment Framework and Literature Review." International Review of Environmental and Resource Economics 4: 261-354.

Lasse, Ringius, Asbjorn Torvanger and Arild Underdal. 2002. "Burden Sharing and Fairness 
Principles in International Climate Policy," International Environmental Agreements: Politics, Law and Economics 2(1): 1-22.

Libecap, Gary D. 1978. "Economic Variables and the Development of the Law: The Case of

Western Mineral Rights." Journal of Economic History 38 (2): 338-62.

Libecap, Gary D. 1989a. Contracting for Property Rights, New York: Cambridge University Press.

Libecap, Gary D. 1989b. "The Political Economy of Crude Oil Cartelization in the United States, 1933-1972." Journal of Economic History 49(4): 833-55.

Libecap, Gary D. and James L. Smith. 1999. "The Self-Enforcing Provisions of Oil and Gas Unit Operating Agreements: Theory and Evidence." Journal of Law, Economics, and Organization 15 (2): 526-48.

Libecap, Gary D. and James L. Smith. 2001. "Regulatory Remedies to the Common Pool: the Limits of Oil Field Unitization," Energy Journal 22 (1): 1-26.

Libecap, Gary D. and James L. Smith. 2002. "The Economic Evolution of Petroleum Property Rights in the United States." Journal of Legal Studies 31 (2, Pt. 2): S589-S608.

Libecap, Gary D. and Steven N. Wiggins. 1984. "Contractual Responses to the Common Pool: Prorationing of Crude Oil Production," The American Economic Review, 74 (1): 87-98. Libecap, Gary D. and Steven N. Wiggins. 1985. "The Influence of Private Contractual Failure on Regulation: The Case of Oil Field Unitization,” Journal of Political Economy 93 (4): 690-714.

Lischewski, Christopher. 2010. "Preface" in Robin Allen, James Joseph, and Dale Squires eds, (2010), Conservation and Management of Transnational Tuna Fisheries, Ames: WileyBlackwell, pp. xi-xvi.

Ling, Bing.1992. "Developing Countries and Ozone Layer Protection: Issues, Principles, and Implications, Tulane Environmental Law Journal 6:91.

Lindroos, Marko. 2002. "Coalitions in Fisheries." Working paper. Helsinki School of Economics.

Litfin, Karen T. 1994. Ozone Discourse: Science and Politics in Global Environmental Cooperation. New York: Columbia University Press.

Lueck, Dean and Jeffrey A. Michael. 2003. "Preemptive Habitat Destruction Under the Endangered Species Act," Journal of Law and Economics, 46: 27-60.

Mabunda, David, Danie J. Pienaar, and Johan Verhoef. 2003. "The Kruger National Park: A Century of Management and Research.” In Harry C. Biggs, Johan T. du Toit, Kevin H. Rogers, Anthony R.E. Sinclair eds, The Kruger Experience: Ecology and Management of Savanna Heterogeneity, Washington, DC: Island Press, 3-21.

Maguire, Jean-Jacques, Michael Sissenwine, Jorge Csirke, Richard Grainger and Serge Garcia. 2006. "The State of World Highly Migratory, Straddling and Other High Seas Fishery Resources and Associated Species," FAO Fisheries Technical Paper 495 Rome: United Nations Food and Agricultural Organization.

Mansfield, Edward D. and Helen V. Milner. 2012. Votes, Vetoes and International Trade Agreements: The Domestic and International Politics of Preferential Trade Agreements. Princeton: Princeton University Press.

Mattoo, Aaditya, Arvind Subramanian, Dominique van der Mensbrugghe, and Jianwu He. 2009. "Reconciling Climate Change and Trade Policy." World Bank Policy Research Working Paper 5123. Washington D.C.: The World Bank.

McClurg, Tom. 2012. "A Case Study of High Seas Fisheries Governance: The PNA 
Agreement," paper presented at Tackling the Global Fisheries Challenge, PERC, Bozeman, MT, November 14-15.

McCright, Aaron M. 2010. "The Effects of Gender on Climate Change Knowledge and Concern in the American Public." Population and Environment 32 (1): 66-87.

McDorman, Ted L. 2009. "Canada-United States Cooperative Approaches to Shared Marine Fishery Resources: Territorial Subversion" Michigan Journal of International Law 30: 665-87.

McGinnis, Michael and Elinor Ostrom. 2008. "Will Lessons from Small-Scale Social Dilemmas Scale Up?" In New Issues and Paradigms in Research on Social Dilemmas, ed. Anders Biel, Daniel Eek, Tommy Gärling, and Mathias Gustaffson, Berlin: Springer, 189-211.

McGinty, Matthew, 2007. "International Environmental Agreements among Asymmetric Nations." Oxford Economic Papers 59 (1) : 45-62.

McKibbin, Warwick J., Adele Morris, and Peter J. Wilcoxen. 2010. "Expecting the Unexpected: Macroeconomic Volatility and Climate Policy," in Joseph E. Aldy and Robert N. Stavins, eds, Post-Kyoto International Climate Policy: Implementing Architectures for Agreement, New York: Cambridge University Press, 857-888.

McWhinnie, Stephanie F. 2009. "The Tragedy of the Commons in International Fisheries: An Empirical Examination." Journal of Environmental Economics and Management 57 (3): 321-33.

Meade, James E. 1973. The Theory of Economic Externalities: The Control of Environmental Pollution. Geneva: Institut Universitaire de Hautes Etudes Internationales.

Medema, Steven G. and Rochard O Zerbe, Jr. 2000. "The Coase Theorem.” In Boudewijn Bouckaert and Gerrit De Geest, eds, The Enclyclopedia of Law and Economics Aldershot: Edward Elgar, 418-55.

Mendelsohn, Robert. 2008. "Is the Stern Review an Economic Analysis?" Review of Environmental Economics and Policy 2: 45-60.

Meng, Kyle. 2013. "The Cost of Potential Cap-and-Trade Policy; An Event Study using Prediction Markets and Lobbying Records," working paper, Columbia University, Department of Earth and Environmental Sciences.

Merrill, Thomas W. and Henry E. Smith. 2010. Property, New York: Oxford University Press.

Metcalf, Gilbert E. 2009. "Designing a Carbon Tax to Reduce U.S. Greenhouse Gas Emissions." Review of Environmental Economics and Policy 3(1): 63-83.

Metcalf, Gilbert E., Aparna Mathur, and Kevin A. Hassett. 2012. "Distributional Impacts in a Comprehensive Climate Policy," in Don Fullerton and Catherine Wolfram, eds, The Design and Implementation of US Climate Policy, Chicago: NBER and University of Chicago Press, 21-36.

Metcalf, Gilbert E., and David A. Weisbach. 2009. "The Design of a Carbon Tax." Harvard Environmental Law Review 33(2): 499-556.

Missios, Paul C. 2004. "Wildlife Trade and Endangered Species Protection." Australian Journal of Agricultural and Resource Economics 48 (4): 613-27.

Mitchell, Ronald B. 2010. International Politics and the Environment, Los Angeles: Sage.

Mitchell, Ronald B. 2012. International Environmental Agreements Database Project http://iea.uoregon.edu/.

Miyake, Makoto Peter, Naozumi Miyabe, Hideki Nakano. 2004. Historical Trends of Tuna Catches in the World, Rome: FAO Fisheries Technical Paper 467, Rome: FAO.

Molina, Mario J. and F. Sherwood Rowland. 1974. "Stratospheric Sink for 
Chlorofluoromethanes: Chlorine AtomicCatalyzed Destruction of Ozone." Nature 249: $810-2$.

Munro, Gordon R. 2000. "The United Nations Fish Stocks Agreement of 1995: History and Problems of Implementation." Marine Resource Economics 15 (4):265-80.

Murdoch, James C. and Todd, Sandler. 1997. "The Voluntary Provision of a Pure Public Good: The Case of Reduced CFC Emissions and the Montreal Protocol." Journal of Public Economics 63: 331-49.

Myers, Ransom A. and Boris Worm. 2003. "Rapid Worldwide Depletion of Predatory Fish Communities." Nature 423 (6937): 280-3.

Myers, Erin C. 2007. "Policies to Reduce Emissions from Deforestation and Degradation (REDD) in Developing Countries: An Examination of the Issues Facing the Incorporation of REDD into Market-Based Climate Policies." Discussion Paper 07-05 Washington DC: Resources for the Future.

Na, Seong-lin and Hyun Song Shin. 1998. "International Environmental Agreements under Uncertainty." Oxford Economic Papers, 50(2), 173-185.

Nangle, Orval E. 1989. "Stratospheric Ozone: United States Regulation of Chlorofluorocarbons." Boston College Environmental Affairs Legal Review 16 (3): 531-80.

National Research Council. 1994. An Assessment of Atlantic Bluefin Tuna Committee to Review Atlantic Bluefin Tuna, Ocean Studies Board, Commission on Geosciences, Environment, and Resources, Washington DC: National Academy Press.

Nesbet, Matthew and Teresa Myers. 2007. "Twenty Years of Public Opinion About Global Warming," Public Opinion Quarterly 83(1): 1-17.

Newell, Richard G. and Kristian Rogers. 2003. “The Market-based Lead Phasedown ." Discussion Paper 03-37. Washington D.C.: Resources for the Future. http://www.rff.org/Documents/RFF-DP-03-37.pdf.

Newell, Richard G., William A. Pizer, and Daniel Raimi. 2013. "Carbon Markets 15 Years after Kyoto: Lessons Learned, New Challenges.” Journal of Economic Perspectives 27(1): 1346.

Nordhaus, William D. 2007. "A Review of the Stern Review on the Economics of Climate Change," Journal of Economic Literature 45 (3): 686-702.

Normile, Dennis. 2009. "Scientists Get No Respect From Fishery Managers.” Science 324: 1261.

Odell, John S. 2006. Negotiating Trade: Developing Countries in the WTO and NAFTA. Cambridge University Press.

Olson, Mancur. 1965. The Logic of Collective Action. Public Goods and the Theory of Groups, Cambridge: Harvard University Press.

Olson, David, M. Eric Dinerstein, Eric D. Wikramanayake, Neil D. Burgess, George V. N.Powell, Emma C. Underwood, Jennifer A. D'amico, Illanga Itoua, Holly E. Strand, John C. Morrison, Colby J. Loucks, Thomas F. Allnutt, Taylor H. Ricketts, Yumiko Kura, John F. Lamoreux, Wesley W. Wettengel, Prashant Hedao, and Kenneth R. Kassem. 2001. "Terrestrial Ecoregions of the World: A New Map of Life on Earth.” BioScience 51(11): 933-938.

O'Neill, Kate. 2009. The Environment and International Relations New York: Cambridge University Press.

Ostrom, Elinor. 1990. Governing the Commons: The Evolution of Institutions for Collective Action, New York: Cambridge University Press.

Ostrom, Elinor. 2000. "Collective Action and the Evolution of Social Norms," Journal of Economic Perspectives, 14 (3): 137-58. 
Ostrom, Elinor. 2009, "A General Framework for Analyzing Sustainability of Social-Ecological Systems", Science 325 (5939): 419-22.

Ostrom, Elinor. 2011. "Beyond Markets and States: Polycentric Governance of Complex Economic Systems," The American Economic Review 100 (3): 641-72.

Ostrom, Elinor. 2012. "Nested Externalities and Polycentric Institutions: Must We Wait for Global Solutions to Climate Change Before Taking Actions at Other Scales?" Economic Theory 49 (2): 353-69.

Ostrom, Elinor, Roy Gardner and James Walker. 1994. Rules, Games and Common Pool Resources. Michigan: University of Michigan Press.

Ostrom, Elinor, Joanna Burger, Christopher B Field, Richard B. Nogaard, and David Policansky. 1999. "Revisiting the Commons: Local Lessons, Global Challenges." Science 284 (5412): 278-82.

Ostrom, Elinor, Thomas Dietz, Nives Dolšak, Paul C. Stern, Susan Stonich, and Elke U. Webe, eds. 2002. The Drama of the Commons. Washington, DC: National Academy Press.

Parson, Edward A. 2003. Protecting the Ozone Layer: Science and Strategy. Oxford: Oxford University Press.

Peltzman, Sam. 1976. "Toward a More General Theory of Regulation," Journal of Law and Economics 19 (2): 211-40.

Pfaff, Alexander, Gregory S. Amacher, and Erin O. Sills. 2013. "Realistic REDD: Improving the Forest Impacts of Domestic Policies in Different Settings." Review of Environmental Economics and Policy 7 (1) (January): 114-135.

Pigou, Arthur C. 1920. The Economics of Welfare. London: Macmillan.

Pindyck, Robert S. 2012. "Uncertain Outcomes and Climate Change Policy," Journal of Environmental Economics and Management 63, 289-303.

Pindyck, Robert S. 2013. "Climate Change Policy: What do the Models Tell US?” Journal of Economic Literature, forthcoming.

Pinsky, Malin L., Olaf P. Jensen, Daniel Ricard, and Stephen R. Palumbi. 2011. "Unexpected Patterns of Fisheries Collapse in the World's Oceans." Proceedings of the National Academy of Sciences 108 (20): 8317-22.

Pintassilgo, Pedro and Clara Costa Duarte. 2000. "The New-Member Problem in the Cooperative Management of High Seas Fisheries," Marine Resource Economics 15 (4): 361-78.

Plantinga, Andrew J. and Kenneth R. Richards. 2010. "International Forest Carbon Sequestration in a Post-Kyoto Agreement.” in Joseph E. Aldy and Robert N. Stavins, eds, Post-Kyoto International Climate Policy: Implementing Architectures for Agreement, New York: Cambridge University Press, 682-714.

Polacheck, Tom. 2012. "Politics and Independent Scientific Advice in RFMO Processes: A Case Study of Crossing Boundaries," Marine Policy 36: 132-41.

Polasky, Stephen, Jennifer Schmitt, Christopher Costello, and Lialila Tajibaeva. 2008. "LargerScale Influences on the Serengeti Ecosystem: National and International Policy, Economics, and Human Geography." In Anthony R. E. Sinclair, Craig Packer, Simon A. R. Mduma, and John M. Fryxell, eds, Serengeti III: Human Impacts on Ecosystem Dynamics Chicago: University of Chicago Press. 347-378.

Possingham, Hugh P., Sandy J. Andelman, Mark A. Burgman, Rodrigo A. Medellín, Larry L. Master and David A. Keith. 2002. "Limits to the Use of Threatened Species Lists," Trends in Ecology and Evolution 17 (11): 503-7.

Poteete, Amy R. and Elinor Ostrom. 2004. "Heterogeneity, Group Size and Collective Action: 
The Role of Institutions in Forest Management." Development and Change 35(3): 43561.

Poteete, Amy R, Marco A. Janssen, and Elinor Ostrom. 2010. Working Together: Collective Action, the Commons, and Multiple Methods in Practice, Princeton: Princeton University Press.

Prins, Herbert H. T., and Jan Geu Grootenhuis. 2000. "Introduction: The Value of Priceless Wildlife.” In Herbert H. T Prins ed., Wildlife Conservation by Sustainable Use, Boston: Kluwer Academic Publishers, 1-12.

Rausch, Sebastian and John Reilly. 2012. "Carbon Tax Revenue and the Budget Deficit: A Win-Win Solution?" Report 228, MIT Joint Program on the Science and Policy of Global Change, Cambridge, August.

Rayfuse, Rosemary. 2006. Regional Allocation Issues or Zen and the Art of Pie Cutting. Sharing the Fish Conference, 26 February-2 March. Perth, Australia.

Reeve, Rosalind. 2002. Policing International Trade in Endangered Species: The CITES Treaty and Compliance, London: Earthscan Publications.

Reiner, David M., Thomas E. Curry, Mark A. de Figueiredo, Howard J. Herzog, Stephen D. Ansolabehere, Kazuki Itaoka, Filip Johnsson, and Mikael Odenberger. 2006. "American Exceptionalism? Similarities and Differences in National Attitudes Toward Energy Policy and Global Warming." Environmental Science and Technology 40 (7): 2093-8.

Rose, Adam, Brandt Stevens, Jae Edmonds, and Marshall Wise. 1998. "International Equity and Differentiation in Global Warming Policy: An Application to Tradable Emission Permits." Environmental and Resource Economics 12:25-51.

Rosenthal, Jean-Laurent. 1990. "The Development of Irrigation in Provence, 1700-1860: The French Revolution and Economic Growth." Journal of Economic History 50(3): 615-38.

Rubio, Santiago Jose and Alistair Ulph. 2006. "Self-Enforcing International Environmental Agreements Revisited," Oxford Economic Papers 58:233-63.

Ruttan, Lore M. 2008. "Economic Heterogeneity and the Commons: Effects on Collective Action and Collective Goods Provisioning." World Development 36 (5): 969-85.

Scott, Anthony. 1955. "The Fishery: The Objectives of Sole Ownership," Journal of Political Economy 63: 116-24.

Scruggs, Lyle and Salil Benegal. 2012. "Declining Public Concern about Climate Change: Can We Blame the Great Recession?" Global Environmental Change 22(2): 505-15.

Shepard Jr., Glenn H., Klaus Rummenhoeller, Julia Ohl-Schacherer, and Douglas W. Yu. 2010. "Trouble in Paradise: Indigenous Populations, Anthropological Policies, and Biodiversity Conservation in Manú National Park, Peru,” Journal of Sustainable Forestry. 29(2): 252301.

Shepsle, Kenneth A. and Barry R. Weingast. 1981. "Political Preferences for the Pork Barrel: A Generalization," American Journal of Political Science 25 (1): 96-111.

Sigman, Hilary. 2012. "Monitoring and Enforcement of Climate Policy," in Don Fullerton and Catherine Wolfram, eds, The Design and Implementation of US Climate Policy, Chicago: NBER and University of Chicago Press, 213-25.

Sinclair, Anthony R. E. 1995. "Serengeti Past and "Present," in Anthony R. E. Sinclair and Peter Arcese, eds, Serengeti II: Dynamics, Management, and Conservation of an Ecosystem, Chicago: University of Chicago Press, 3-30.

Singhal, Monica, 2008, "Special Interest Groups and the Allocation of Public Funds." Journal of Public Economics 92 (3-4): 548-64. 
Stavins, Robert N. 2008. "A Meaningful U.S. Cap-and-Trade System to Address Climate Change." Harvard Environmental Law Review 32: 293-371.

Stern, Nicolas. 2007. The Stern Review on the Economics of Climate Change. Cambridge: Cambridge University Press.

Stern, Nicolas. 2013. "The Structure of Economic Modelling of the Potential Impacts of Climate Change: Grafting Gross Underestimation of Risk onto Already Narrow Science Models." Journal of Economic Literature forthcoming.

Stickler, Claudia M., Daniel C. Nepstad, Michael T. Coe, David G. McGrath, Hermann O. Rodrigues, Wayne S. Walker, Britaldo S. Soares-Filho, and Eric A. Davidson. 2009. "The Potential Ecological Costs and Cobenefits of REDD: A Critical Review and Case Study from the Amazon Region." Global Change Biology 15 (12): 2803-24.

Stokke, Olav Schram ed. 2001. Governing High Seas Fisheries: The Interplay of Global and Regional Regimes. New York: Oxford University Press.

Stolarski, Richard S. and Ralph J. Cicerone. 1974. "Stratospheric Chlorine: A Possible Sink for Ozone" Canadian Journal of Chemistry 52: 1610-5.

Taconi, Luca. 2009. "Compensated Successful Efforts for Avoided Deforestation vs. Compensated Reductions." Ecological Economics 68(8-9): 2469-72.

Tarui, Nori, Charles Mason, Stephen Polasky and Greg Ellis. 2008. "Cooperation in the Commons with Unobservable Actions." Journal of Environmental Economics and Management 55: 37-51.

Tingley, Dustin and Michael Tomz. 2012. "Conditional Cooperation and Climate Change," working paper, Department of Government, Harvard University, $\underline{\text { http://scholar.harvard.edu/files/tingleytomzclimatefinal_0.pdf }}$

Ulph, Alistair. 1998. "Learning about Global Warming." in Nick Hanley and Henk Folmer eds. Game Theory and the Environment. Edward Elgar, Cheltenham, UK et al., 255-86.

Ulph, Alistair, ed. 2001. Environmental Policy, International Agreements, and International Trade, New York: Oxford University Press.

Ulph, Alistair. 2004. Stable International Environmental Agreements with a Stock Pollutant, Uncertainty and Learning. Journal of Risk and Uncertainty, 29(1), 53-73.

Ulph, Alistair and David Ulph. 1997. "Global Warming, Irreversibility and Learning." Economic Journal 107(442): 636-50.

UNCLOS. 1982. United Nations Convention on the Law of the Sea. UN Document A/Conf. 62/122.

UNFSA. 1995. Agreement for the Implementation of the Provisions of the United Nations Convention on the Law of the Sea of 10 December 1982 Relating to the Conservation and Management of Straddling Fish Stocks and Highly Migratory Fish Stocks. UN Document A/Conf.164/37.

United Nations (UN). 1982. United Nations Convention on the Law of the Sea. U.N. Doc. A/Conf. 62/122.

United Nations (UN). 1995. Agreement for the Implementation of the Provisions of the United Nations Convention on the Law of the Sea of 10 December 1982 Relating to the Conservation and Management of Straddling Fish Stocks and Highly Migratory Fish Stocks. U.N. Doc. A/Conf.164/37.

United Nations, Ozone Secretariat. 1995. Seventh Meeting of the Parties to the Montreal Protocol on Substances that Deplete the Ozone Layer, http://www.unep.ch/ozone/7mpviefn.htm. 
United Nations, Ozone Secretariat. 1998. 1997 Update of the Handbook for the Montreal Protocol on Substances that Deplete the Ozone Layer, New York: United Nations.

United Nations, Ozone Secretariat. 2010. The 2010 Assessment of the Scientific Assessment Panel http://ozone.unep.org/Assessment_Panels/SAP/Scientific_Assessment_2010/index.s $\underline{\mathrm{html}}$

United States, EPA. 2010. Technical Support Document: Social Cost of Carbon for Regulatory Impact Analysis Under Executive Order 12866. Washington DC. Interagency Working Group on Social Cost of Carbon.

United States, Interagency Working Group on Social Cost of Carbon. 2010. "Technical Support Document: Social Cost of Carbon for Regulatory Impact Analysis." Washington DC.

United States, Interagency Working Group on Social Cost of Carbon. 2013. Technical Support Document: Technical Update of the Social Cost of Carbon for Regulatory Impact Analysis Under Executive Order 12866. May.

Upton, Simon, and Vandelis Vitalis. 2003. Stopping the High Seas Robbers: Coming to Grips with Illegal, Unregulated, and Unreported Fishing on the High Seas. OECD Round Table on Sustainable Development. Paris.

Van Dyke, Jon M. 2010. "Allocating Fish across Jurisdictions." in Conservation and Management of Transnational Tuna Fisheries, edited by Robin Allen, James Joseph and Dale Squires, Oxford, UK: Wiley-Blackwell, 163-79.

Varughese, George, and Elinor Ostrom. 2001. "The Contested Role of Heterogeneity in Collective Action: Some Evidence from Community Forestry in Nepal." World Development 29 (5): 747-65.

Velders, Guus J.M., Stephen O. Andersen, John S. Daniel, David W. Fahey and Mack McFarland. 2007. "The Importance of the Montreal Protocol on Protecting Climate." Proceedings of the National Academy of 104 (12): 4814-9.

Victor, David G. 2011. Global Warming Gridlock: Creating More Effective Strategies for Protecting the Planet, New York: Cambridge University Press.

Viscusi, W. Kip and Richard Zeckhauser 2006. "The Perception and Valuation of the Risks of Climate Change: A Rational and Behavioral Blend," Climatic Change 77(2): 151-77.

Volden, Craig and Alan E. Wiseman. 2007. "Bargaining in Legislatures over Particularistic and Collective Goods," American Political Science Review, 101 (1): 79-92.

Vukas, Budislav and Davor Vidas. 2001. "Flags of Convenience and High Seas Fishing: The Emergence of a Legal Framework," in Olav Schram Stokke, ed. 2001. Governing High Seas Fisheries: The Interplay of Global and Regional Regimes. New York: Oxford University Press, 53-61.

Wade, Robert. 1988. Village Republics. Economic Conditions for Collective Action in South India. New York: Cambridge University Press.

Webster, D.G. 2010. "Quasi-Property Rights and the Effectiveness of Atlantic Tuna Management." in Conservation and Management of Transnational Tuna Fisheries, edited by Robin Allen, James Joseph and Dale Squires, Oxford, UK: Wiley-Blackwell, 321-32.

Weingast, Barry R. 1994. "Reflections on Distributive Politics and Universalism." Political Research Quarterly 47: 319-327.

Weingast, Barry R., Kenneth A. Shepsle, and Christopher Johnsen. 1981. "The Political Economy of Benefits and Costs: A Neoclassical Approach to Distributive Politics." Journal of Political Economy 89 (4):642-64.

Weitzman, Martin L. 2007. "A Review of The Stern Review of the Economics of Climate 
Change." Journal of Economic Literature 45 (3): 703-24.

Weitzman, Martin L. 2013. "Tail-Hedge Discounting and the Social Cost of Carbon." Journal of Economic Literature forthcoming.

Wiener, Jonathan Baert. 2007. "Think Globally, Act Globally; The Limits of Local Climate Change Policies." University of Pennsylvania Law Review, 155: 101-119.

Wiggins, Steven N. and Gary D. Libecap. 1985. "Oil Field Unitization: Contractual Failure in the Presence of Imperfect Information," American Economic Review 75(3): 368-85.

Williamson, Oliver E. 1979. "Transaction Cost Economics: The Governance of Contractual Relations." Journal of Law and Economics 22 (2): 233-61.

Williamson, Oliver E. 2010. "Transaction Cost Economics: The Natural Progress." The American Economic Review 100(3): 673-90.

Worm, Boris, Ray Hilborn, Julia K. Baum, Trevor A. Branch, Jeremy S. Collie, Christopher Costello, Michael J. Fogarty, Elizabeth A. Fulton, Jeffrey A. Hutchings, Simon Jennings, Olaf P. Jensen, Heike K. Lotze, Pamela M. Mace, Tim R. McClanahan, Cóilín Minto, Stephen R. Palumbi, Ana M. Parma, Daniel Ricard, Andrew R. Rosenberg, Reg Watson, and Dirk Zeller. 2009. "Rebuilding Global Fisheries." Science 325 (5940): 578-85.

Young, Oran R. 1994. "The Problem of Scale in Human/Environmental Relationships." Journal of Theoretical Politics 6 (4): 429-47.

Young, Oran R. 2010. Institutional Dynamics: Emerging Patterns in International Environmental Governance, Cambridge: MIT Press.

Young, Oran R. 2011. "Effectiveness of International Environmental Regimes: Existing Knowledge, Cutting-edge Themes, and Research Strategies," Proceedings of the National Academy of Sciences, www.pnas.org/cgi/doi/10.1073/pnas.1111690108 